\title{
The depositional and diagenetic history of the Permian Quartermaster Group of western Kansas
}

Joseph James Pritt

Follow this and additional works at: https://researchrepository.wvu.edu/etd

\section{Recommended Citation}

Pritt, Joseph James, "The depositional and diagenetic history of the Permian Quartermaster Group of western Kansas" (2016). Graduate Theses, Dissertations, and Problem Reports. 6454.

https://researchrepository.wvu.edu/etd/6454

This Thesis is protected by copyright and/or related rights. It has been brought to you by the The Research Repository @ WVU with permission from the rights-holder(s). You are free to use this Thesis in any way that is permitted by the copyright and related rights legislation that applies to your use. For other uses you must obtain permission from the rights-holder(s) directly, unless additional rights are indicated by a Creative Commons license in the record and/ or on the work itself. This Thesis has been accepted for inclusion in WVU Graduate Theses, Dissertations, and Problem Reports collection by an authorized administrator of The Research Repository @ WVU. For more information, please contact researchrepository@mail.wvu.edu. 


\title{
Improving Seeding and Mulching Specifications In West Virginia and Creating a Materials Estimate Tool
}

\author{
Forrest N. Pritt
}

Thesis submitted

to the Benjamin M. Statler College of Engineering and Mineral Resources at West Virginia University

in Partial fulfillment of the requirements for the degree of

Master of Science in

Civil and Environmental Engineering

Leslie Hopkinson, Ph.D., Chair

Lian-Shin Lin, Ph.D.

John Quaranta, Ph.D.

Department of Civil and Environmental Engineering

Morgantown, West Virginia

2017

Keywords: vegetation, erosion control, specifications, seeding and mulching, materials estimate tool

Copyright 2017 Forrest N. Pritt 


\title{
Abstract \\ Improving Seeding and Mulching Specifications In West Virginia and Creating a Materials Estimate Tool
}

\author{
Forrest N. Pritt
}

Vegetation is established following construction through various seeding and mulching practices. Environmental permits in West Virginia require a minimum of $70 \%$ of ground cover by area for release of a construction site. The West Virginia Division of Highways (WVDOH), like many other states, has specifications for temporary and permanent seeding and mulching practices. This research critically evaluated the best management practices (BMPs) utilized in the WVDOH specifications, developed recommended revisions to the specifications, and created supplemental materials for future application.

Recommended revisions to the WVDOH include: topsoil, improved soil tests, rolled erosion control products (RECPs), biological growth stimulants (BGSs), hydraulic growth mediums (HGMs), and different types of hydraulic erosion control products (HECPs). Topsoil contains many important properties for the establishment and longevity of vegetation, such as organic matter, water, minerals, and microorganisms. BGSs are a source for organic matter and other important nutrients for vegetation. HGMs are products that can be used as a direct topsoil replacement in areas topsoil may not be available. Soil testing determines the amount of soil amendments to add to the soil for optimal vegetation results, such as limestone, fertilizer, and organic matter. Mulching procedures, such as HECPs and RECPs, were added based on their effectiveness in erosion prevention during seed germination and long term vegetation establishment. The most effective methods in each of the BMPs were added to a revised version of the WVDOH specifications.

A materials estimate tool was created to assist in the application of the revised specifications. The tool takes information about a construction area to determine the most cost effective method of seeding and mulching. The tool compares different methods within the revised specifications to guide a user to choose the most efficient practices for a site. The tool creates a custom output to allow a user to create a detailed cost analysis of applying the seeding and mulching BMPs within the revised specifications to a construction site. Three case studies were developed with this research to show the applicability of the tool. The results of the case studies show the price comparisons of applying seeding and mulching to each site. 


\section{Acknowledgements}

Many people have helped me throughout the duration of this research. I would like to thank my research advisor, Dr. Leslie Hopkinson, for her continued guidance during this project. She is exceptional at finding small errors and recommending the best remedy. I am also thankful for the guidance and help of my research committee consisting of Dr. Leslie Hopkinson, Dr. John Quaranta, and Dr. Lian-Shin Lin. They have all provided motivation for me to become better in civil engineering and my professional life for many years.

I would also like to thank members of the technical advisory committee for this research project. Members of the West Virginia Division of Highways, Charlie Riling, Donald Williams, and Michael Pumphrey, were a great help with their continued input in the project. I would also like to thank Jeremy Hayhurst from Pennington Seed and Steve Zwilling from Profile Products for their input and comments on the specifications side of the research.

I would also like to thank the other research students that assisted with this project. Marissa Poultney, Matt Hudson, and Katelyn Kosar all spent a significant amount of their time assisting me by proofreading long specification documents and performing tests on the materials estimate tool.

Finally, I would like to thank my parents, Lester and Cindy Pritt. They have supported me all of my life to become the best I can be in all aspects of my life. I would not be where I am today without their continued support. 


\section{Grant Information}

The contents of this report reflect the views of the author who is responsible for the facts and the accuracy of the data presented herein. The contents do not necessarily reflect the official views or policies of the State. This report does not constitute a standard, specification, or regulation. Trade or manufacturers' names, which may appear herein, are cited only because they are considered essential to the objectives of this report. The State of West Virginia does not endorse products or manufacturers. Prepared for the West Virginia Department of Transportation Division of Highways. 


\section{Table of Contents}

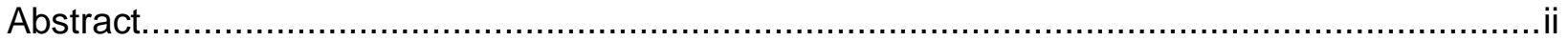

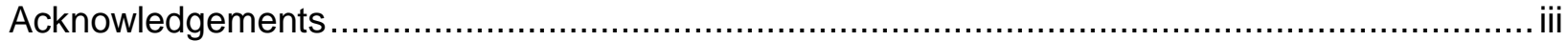

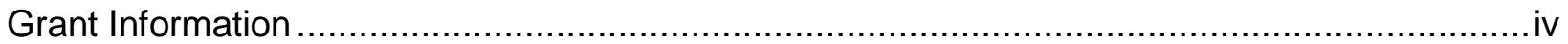

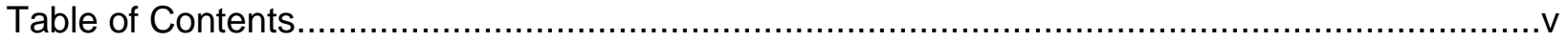

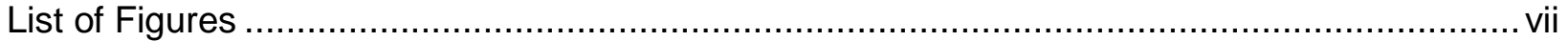

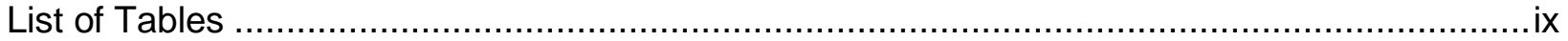

Ch. 1 Introduction:

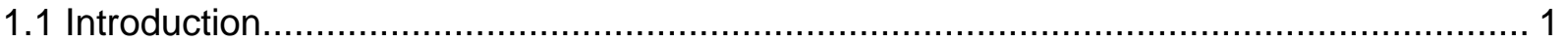

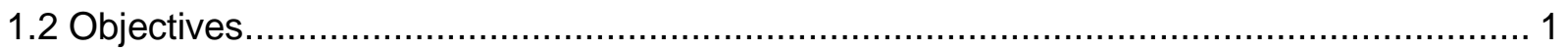

Ch. 2 Revised Specifications for Permanent Seeding ………............................................. 3

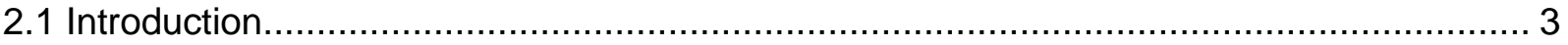

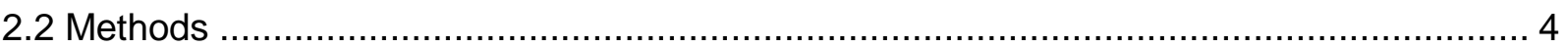

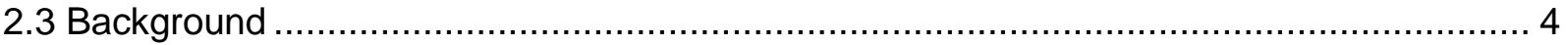

2.3.1 Best Management Practices for Establishing Vegetation for Erosion Control ............. 4

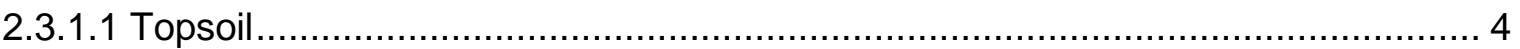

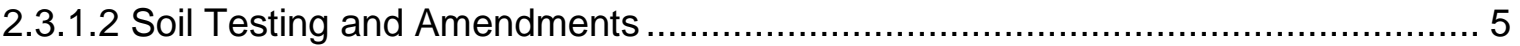

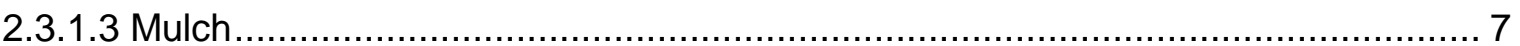

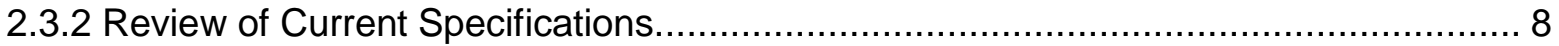

2.3.2.1 WVDOH Section 642: Temporary Pollution Control ........................................... 8

2.3.2.2 WVDOH Section 651: Furnishing and Placing Topsoil....................................... 8

2.3.2.3 WVDOH Section 652: Seeding and Mulching .................................................... 9

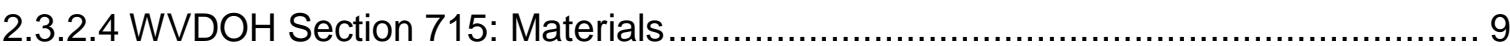

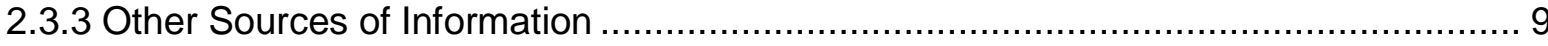

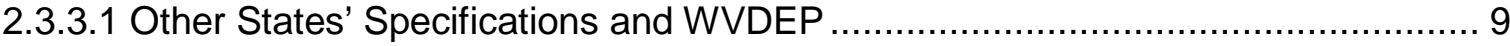

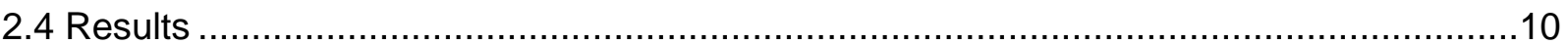

2.4.1 WVDOH Section 642: Temporary Pollution Control ..............................................11

2.4.2 WVDOH Section 651: Furnishing and Placing Topsoil ..........................................11

2.4.3 WVDOH Section 652: Seeding and Mulching......................................................

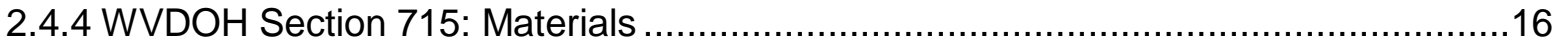

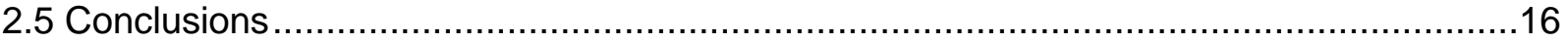

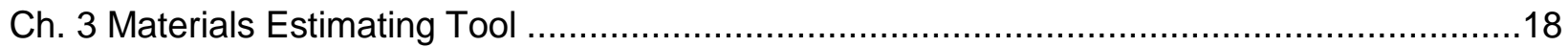




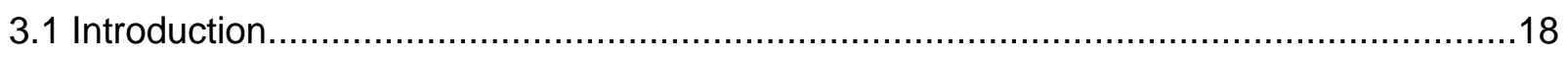

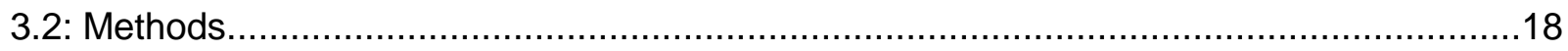

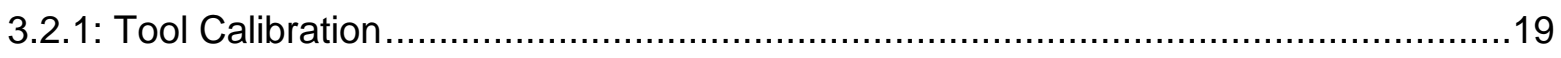

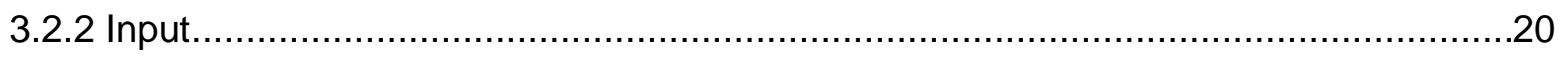

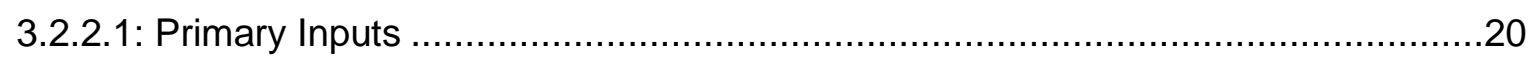

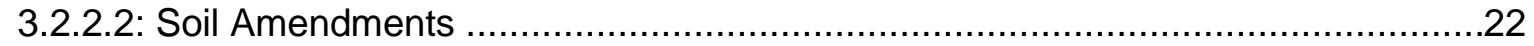

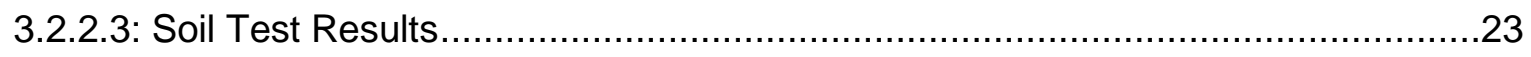

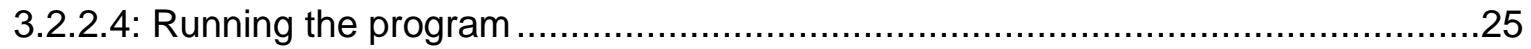

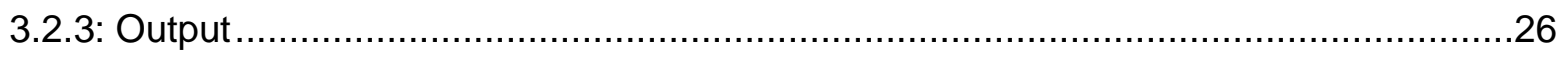

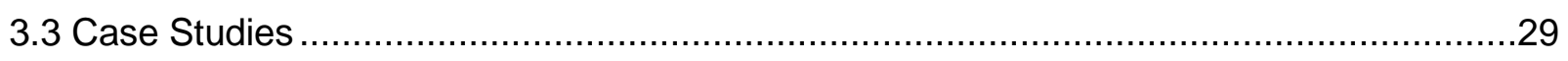

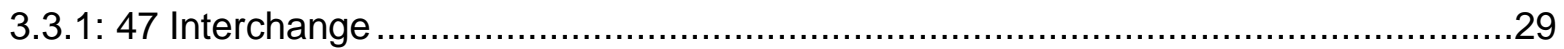

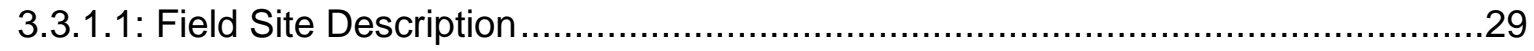

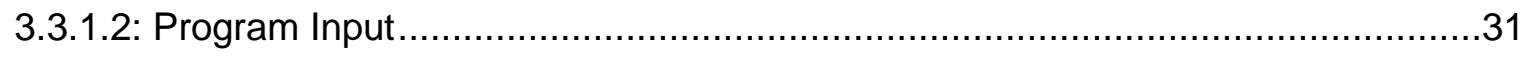

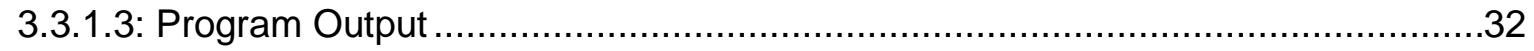

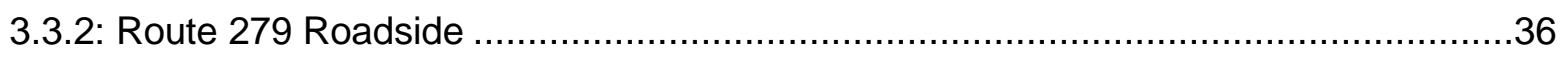

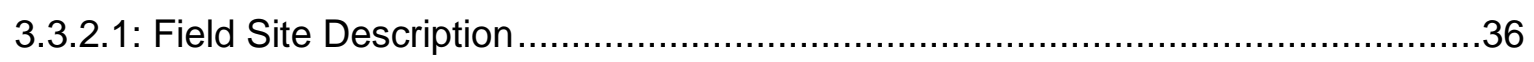

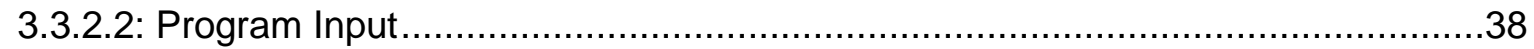

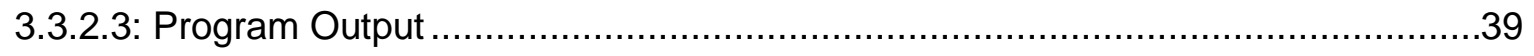

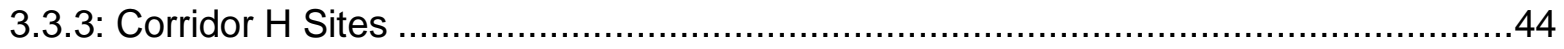

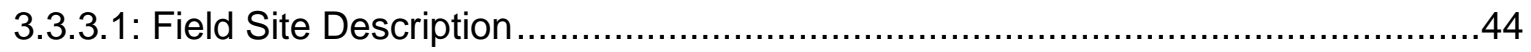

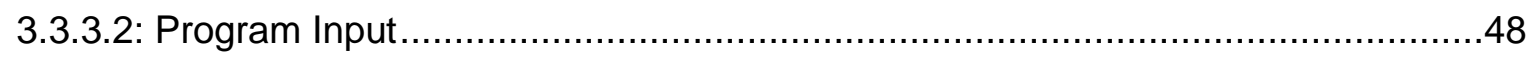

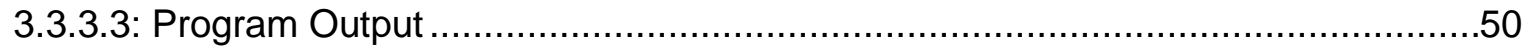

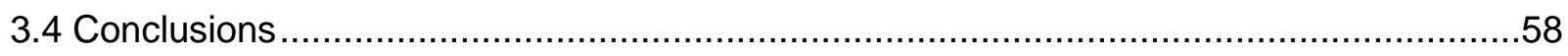

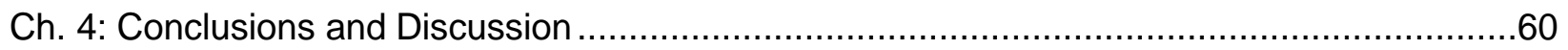

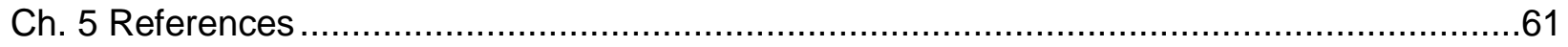

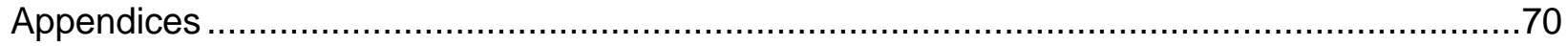

Appendix A: Revised WVDOH Section 642 ...................................................................

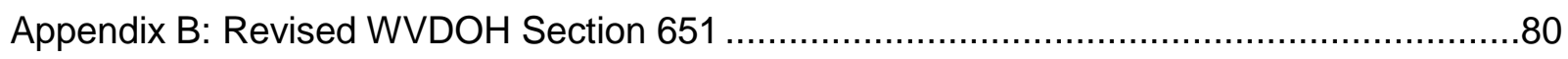

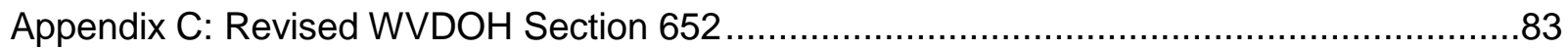

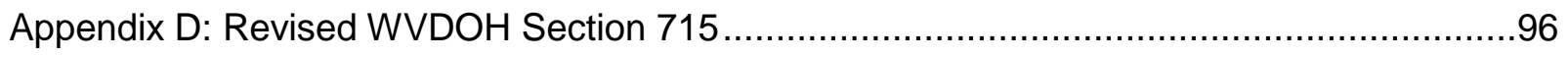




\section{List of Figures}

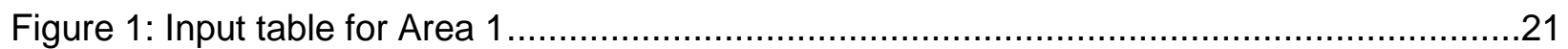

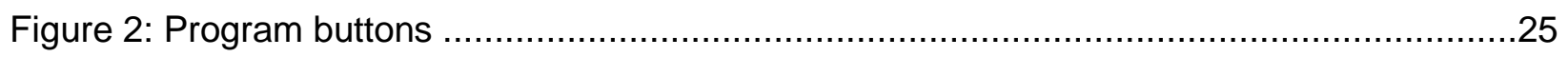

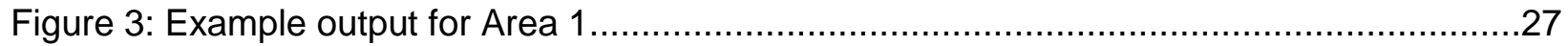

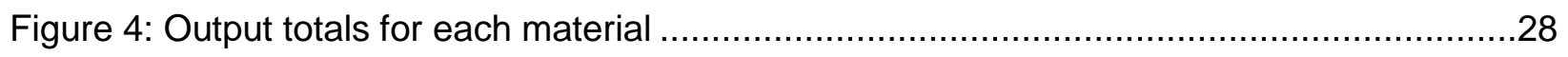

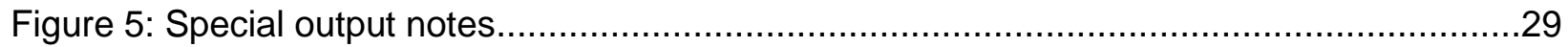

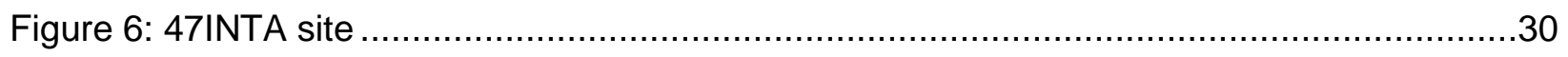

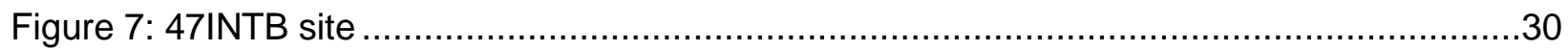

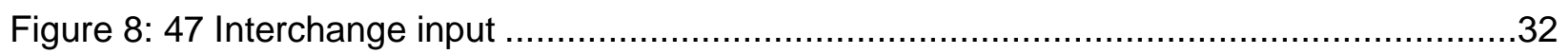

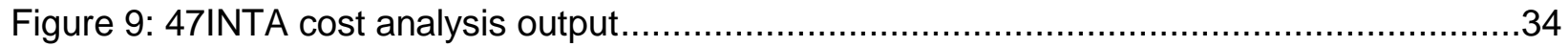

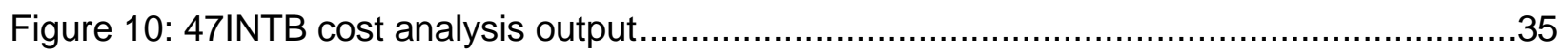

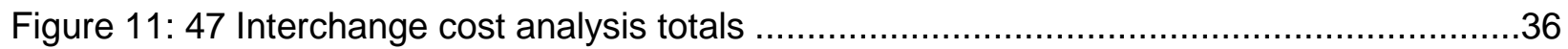

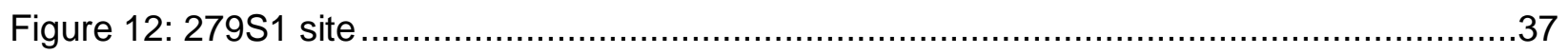

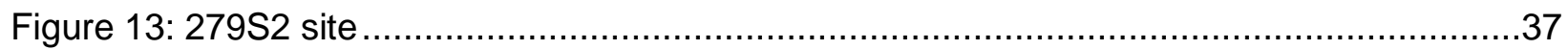

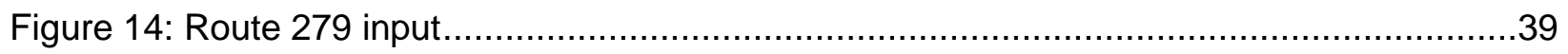

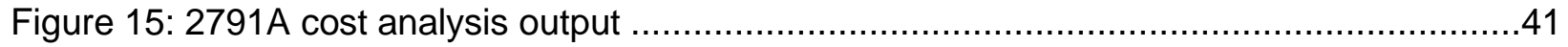

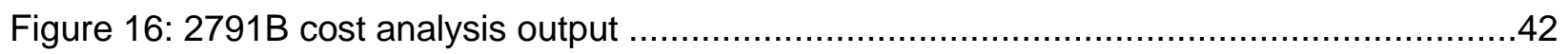

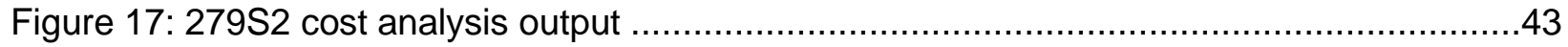

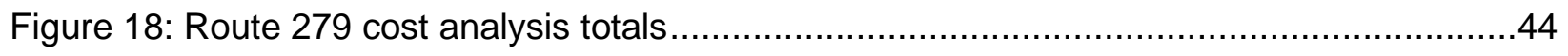

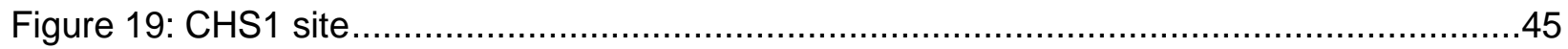

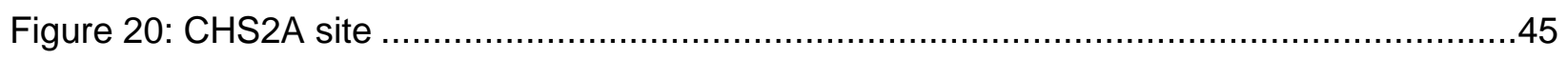

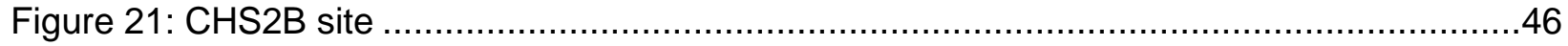

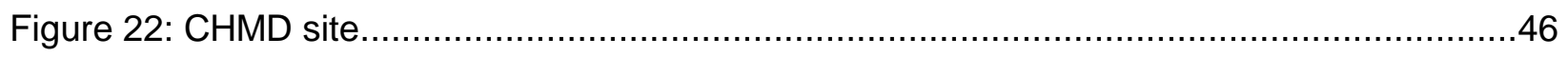

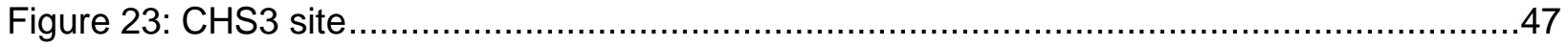

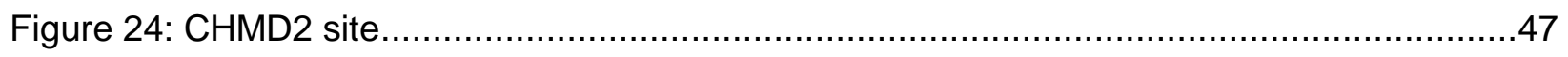

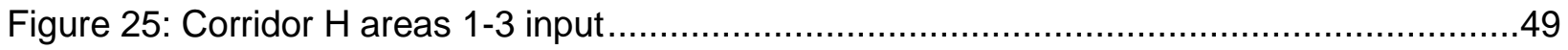

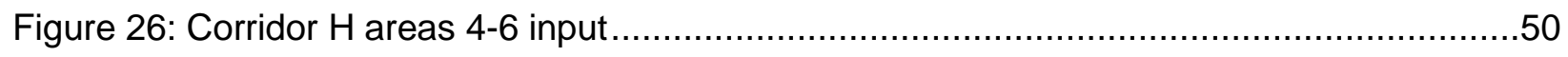

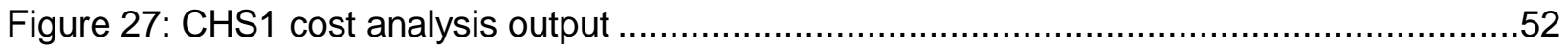

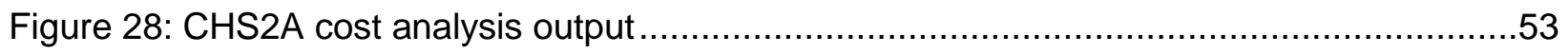

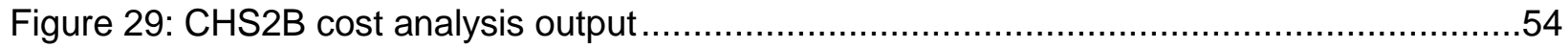




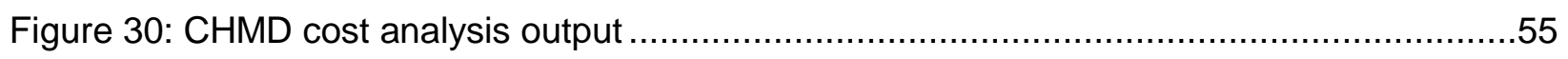

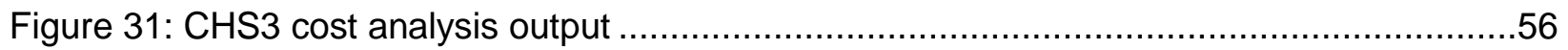

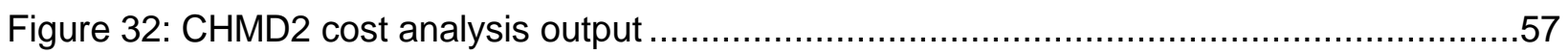

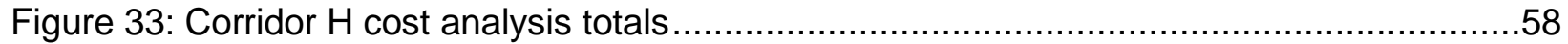




\section{List of Tables}

Table 1: Comparison of different state specification publications ..................................... 3

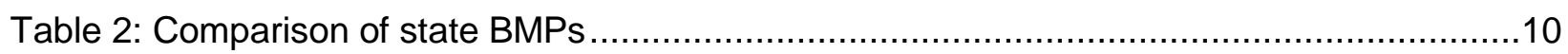

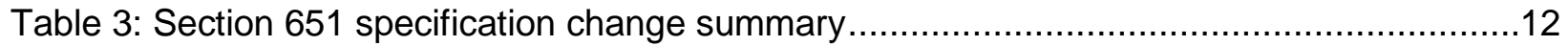

Table 4: Section 652 specification change summary ...............................................

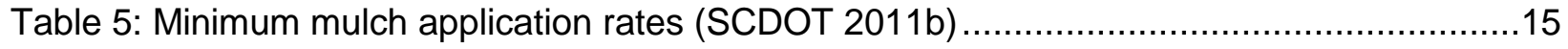

Table 6: Average Price of Common Fertilizers ...................................................19

Table 7: Options for slope, type of seed, and type of mulch as drop down options in tool .........22

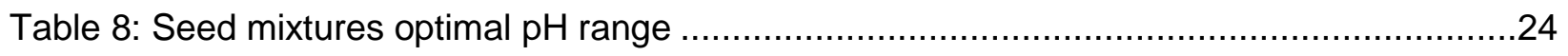

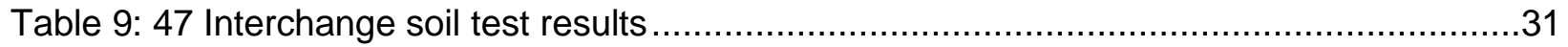

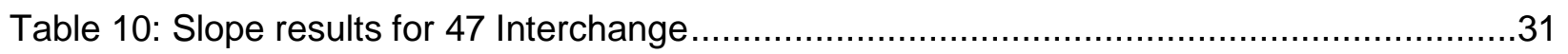

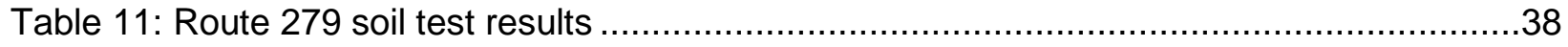

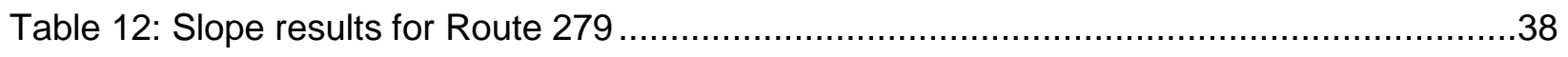

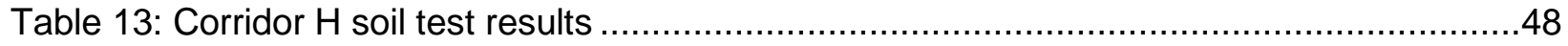

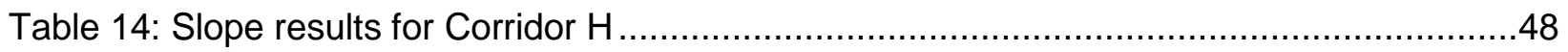




\section{Ch. 1 Introduction:}

\subsection{Introduction}

The state of West Virginia has a history of poor vegetation along roadsides (Hopkinson et al. 2016). Vegetation is the most effective way to eliminate erosion on soil slopes (Perry 2003, Musick and Stenn 2004). Improving the seeding and mulching specifications for the West Virginia Division of Highways (WVDOH) is a major step in improving the quality of roadside vegetation around West Virginia and reducing erosion.

The most effective way to improve the seeding and mulching specifications is to identify the current best management practices (BMPs) and limitations therein. After limitations are found, the BMPs can be researched to find the most effective methods of application. Additional BMPs can also be found and incorporated into the specification to further improve vegetation quality and thus reduce erosion of soil.

The correct application of BMPs are crucial to the establishment of proper vegetation. In order to assist in this, a tool in Microsoft Excel was created to assist in the cost estimation using the new BMPs in the revised specifications. The tool takes a dynamic user input to calculate the amount and cost of seeding, soil amendments, and mulching for permanent seeding on a construction site. The tool assists in helping the user compare different BMPs and show the correct application rates for different properties of a construction site.

\subsection{Objectives}

The overall goal of this work was to investigate BMPs pertaining to vegetation cover for the state of West Virginia. Specific objectives to accomplish this include the following:

1. Evaluate and rewrite current WVDOH specifications on permanent seeding and mulching and all other sections pertinent to seeding after construction.

2. Create a tool to assist in the cost calculation and comparison of permanent seeding and mulching materials within the revised specifications.

Objective 1 required research and understanding of the current WVDOH specifications, other available specifications, and additional sources, such as industry professionals. This research identified BMPs within each specification and limitations associated with each. The data from each source was compared and contrasted to determine the most effective BMPs. The most effective BMPs were chosen based on performance, cost, and professional recommendation.

Objective 2 created a tool that helps a user to choose the optimal BMPs for a construction site. The tool takes inputs from the user to determine the most effective BMPs to apply to a certain construction area to provide for the optimal vegetation cover. The tool compares the three mulching techniques, hydraulic erosion control product (HECP), rolled erosion control product (RECP), and straw, for the user to choose the most feasible option in terms of usefulness and cost. The tool also compares results from a soil test for an area to 
determine the most efficient rates of fertilizer, limestone, and hydraulic growth mediums (HGMs). The tool provides the user with a concise output for the user to create a cost estimation for permanent seeding and mulching on a construction site. 


\section{Ch. 2 Revised Specifications for Permanent Seeding}

\subsection{Introduction}

Objective 1 of this research focused on improving seeding and mulching specifications in the state of West Virginia. Current WVDOH specifications were written in 2000 with minor changes in 2010 (WVDOH 2000, WVDOH 2010). Table 1 shows the recent and previous versions of specifications from the West Virginia Division of Environmental Protection (WVDEP) and states' Department of Transportation (DOT) near West Virginia. Many states near West Virginia have updated their specifications in the current year and typically update their specifications every 2-5 years.

Table 1: Comparison of different state specification publications

\begin{tabular}{|c|c|c|}
\hline State & Current Version & Prior Version \\
\hline Pennsylvania & 2016 (PennDOT 2016) & 2011 (PennDOT 2011) \\
\hline Maryland & 2008 (MDOT 2008) & 2001 (MDOT 2008) \\
\hline Virginia & 2016 (VDOT 2016) & 2007 (VDOT 2007) \\
\hline Kentucky & 2012 (KYTC 2012) & 2008 (KYTC 2007) \\
\hline Ohio & 2016 (ODOT 2016) & 2013 (ODOT 2013) \\
\hline North Carolina & 2012 (NCDOT 2012) & 2006 (NCDOT 2006) \\
\hline South Carolina & 2011 (SCDOT 2011a) & 2007 (SCDOT 2007) \\
\hline Indiana & 2016 (INDOT 2016) & 2014 (INDOT 2014) \\
\hline Michigan & 2012 (MiDOT 2011) & 2003 (MiDOT 2003) \\
\hline Minnesota & 2016 (MnDOT 2015) & 2014 (MnDOT 2013) \\
\hline Wisconsin & 2017 (WisconsinDOT 2016) & 2016 (WisconsinDOT 2016) \\
\hline New York & 2016 (NYSDOT 2016) & 2015 (NYSDOT 2015) \\
\hline WVDEP & 2006 (WVDEP 2006) & \\
\hline
\end{tabular}

A change in vegetation cover practices is needed in West Virginia to improve ground cover on highway right-of-way locations. Hopkinson et al. (2016) found in a study of 39 right of way locations around West Virginia that $28 \%$ of sites had poor cover (<50\% cover), and approximately $50 \%$ of the sites did not meet the minimum requirement of $70 \%$ cover as defined by WVDEP's National Pollutant Discharge Elimination System (NPDES) (WVDEP 2006).

This research can lead to reduced cost of maintenance while improving long-term vegetation cover at highway right of way locations. Vegetation cover prevents erosion and sedimentation runoff (Perry 2003). Preventing erosion and runoff is crucial on large highway cuts and fills to reduce the possibility of a hill slide. Erosion of soil can also carry sediment and 
nutrients away from the soil and deposit them into nearby sources of clean water, polluting them (Paerl et al. 2014).

\subsection{Methods}

This research started with a review of the current WVDOH specifications for seeding and mulching and all pertinent sections. The sections were reviewed to create an understanding of the BMPs currently in use. After creating an understanding of the BMPs in the WVDOH specifications, other states with similar climate to West Virginia as well as the WVDEP specifications were reviewed. The other states and WVDEP provided new BMPs that could be analyzed. The BMPs identified from the current WVDOH specifications and other states were researched to identify limitations within each.

The major BMPs reviewed in this research were topsoil, soil testing and amendments, and mulching practices. Each BMP contains practices that are crucial for beginning or maintaining healthy vegetation growth. These practices were compared with all of the specifications reviewed to find the most common practices. These common principles were researched to find the optimum method of applying each practice.

After review of all sources and comparison built, the current WVDOH sections were modified or new sections added accordingly. The sections were peer reviewed periodically to ensure readability and uniformity. The modifications were also read over and discussed with members of the WVDOH and professionals from the seeding and mulching industry.

\subsection{Background}

Four sections were the focus of this research (WVDOH 2010):

1. Section 642: Temporary Pollution Control

2. Section 651: Furnishing and Placing Topsoil

3. Section 652: Seeding and Mulching

4. Section 715: Materials

Under the review of these sections, three main BMPs were identified: topsoil, soil testing and amendments, and mulch. These BMPs were researched to provide an understanding of the most important properties of each BMP. This knowledge could also be used to identify limitations within the WVDOH specifications. A description of each BMP follows.

\subsubsection{Best Management Practices for Establishing Vegetation for Erosion Control}

\subsubsection{Topsoil}

Topsoil is arguably the most important aspect in vegetation establishment. Quality topsoil is the biggest factor to having quality vegetation with high growth rates, health, and visual appearance (Koenig and Isaman 2010). The main components of topsoil are minerals, water, organic matter, and other trace microorganisms. Minerals, or the sands, silts, and clays, in a soil make up the main soil structure while the other components all assist in vegetation growth (DeGomez et al. 2015). 
Organic matter in the topsoil enhances soil properties such as structure, water infiltration, and water-holding capacity (Koenig and Isaman 2010). The most notable function of organic matter is the water-holding capacity. Organic matter can hold water to be used later by plants as needed and can also improve soils with poor water-holding capacity such as sand (DeGomez et al. 2015).

Water in topsoil is crucial for nutrient transport and decomposition. Topsoil, like all soil, is made up of densely packed soil particles that can restrict movement of nutrients and microorganisms in the soil. Vegetation would not have access to trapped nutrients and microorganisms without water in the soil, which is approximately $2 \%$ to $50 \%$ of the soil volume (DeGomez et al. 2015).

Microorganisms in soils are found in very high numbers but take up less than $1 \%$ of the soil volume. Microorganisms decompose organic matter in soil to release nutrients vital for plant growth. Certain microorganisms, such as mycorrhizae, can form relationships with plants in order to more effectively exchange nitrogen or provide plant roots with sugar essential for growth (DeGomez et al. 2015).

Topsoil purity is a significant quality when analyzing topsoil properties. Topsoil that is not free of live seed can influence non-planted species to grow and restrict the planted species from growing. A study performed by Hölzel and Otte (2003) showed that impure topsoil can prevent new species from growing. The study removed all of the topsoil from the site in order to grow new species. The results showed that without the organic matter and nutrients provided by topsoil, the new species did not grow as well as desired. It took over three years before a large diversity of species from the new seed bank were observed (Hölzel and Otte 2003).

\subsubsection{Soil Testing and Amendments}

Soil testing provides the current conditions of the soil and how these conditions can be improved to provide for optimum vegetation growth. Soil testing can provide values for properties of the soil such as $\mathrm{pH}$, percent organic matter, concentrations of nutrients, cationexchange capacity, and soluble salt concentration. Soil testing that reports these values can provide recommendations for the type and amount of soil amendments to be added.

Soil amendments are used to condition the quality of the soil. Soil amendments can include fertilizer, limestone, biological growth stimulants (BGSs), organic matter, and inorganic matter (Davis and Whiting 2013). Soil amendments can be used to change many properties of the soil including soil structure, nutrients, $\mathrm{pH}$, water retention and capacity, and cation exchange capacity (Davis and Whiting 2013).

Fertilizer is used to add nutrients to the soil that vegetation uses for growth. The main nutrients added by fertilizer are nitrogen, phosphorus, and potassium (Masabni et al. 2009). Ideal levels of nutrients in soil depends on many factors such as soil type, type of vegetation expected, and cation exchange capacity (Buchholz 1983). 
Limestone may be added to soil to improve the $\mathrm{pH}$. The $\mathrm{pH}$ of the soil is a major factor that affects plant growth. The ideal pH of a soil is between 5.5 and 7.0 (Perry 2003; UMassAmherst 2011). Limestone can come in different forms that provide different ways to remediate the $\mathrm{pH}$ in the soil. The most common use of limestone is in the use of agricultural granular limestone, which provides a slow, long-term change in the $\mathrm{pH}$ (Kozicki 2014). Another form of limestone can come in a fast-acting powder or liquid limestone that provides immediate soil $\mathrm{pH}$ remediation (Mitchell and Kessler 2006). The smaller particles in fast-acting limestone react with soil better than coarse aggregates in granular limestone to provide uniform remediation of the soil (Buchholz 1993; Mitchell and Kessler 2006).

Organic matter comes in many different forms including plant residue, manure, sewage sludge, or wastes from organic processing plants (Lewandowski 2002). Organic matter provides benefits to the soil such as increased nutrient holding capacity, improved water filtration and holding capacity, and improved aeration (Lewandowski 2002; Davis and Whiting 2013). The improved aeration and infiltration allows for more pore space in the soil which reduces the bulk density. Whenever the bulk density of soil reaches a certain limit, root growth is restricted and nutrients and water cannot move freely in the soil to reach the roots (Duiker 2004).

The benefits of organic matter increase as organic matter content increases. High levels of organic matter are difficult to obtain, so ideal levels of organic matter ranges within 3\%-6\%, depending on the type of soil (Fenton et al. 2008). An example of how high levels of organic matter are important is provided by Lewandowski (2002). Lewandowski (2002) found that a $0.5 \%$ decrease in organic matter in loamy sand ( $5 \%$ clay) or silt loam ( $20 \%$ clay) reduced nutrient holding capacity by $14 \%$ and $4 \%$, respectively.

BGSs are soil amendments that increase organic matter in soil, microbial activity in soil, and macronutrient and micronutrient uptake into plant roots (SCDOT 2011a; Jardin 2015). BGSs can also increase plant growth during periods of water stress (Zhang and Schmidt 2000; Kauffman et al. 2007). BGSs contain many parts in order to enhance soil properties to allow for optimal plant growth. These parts include humic substances, protein hydrolysates, seaweed extract, inorganic compounds, and micronutrients such as fungi and bacteria (Jardin 2015).

Humic substances are composed of organic matter from plant, animal, and microbial residues derived from peat, compost, or volcanic soils that make up most of the organic matter in soil (Jardin 2015). Protein hydrolysates provide the main amino acids to plants (Jardin 2015). Amino acids play multiple roles as biostimulates of plant growth (Jardin 2012; Calvo et al. 2014; Halpern et al. 2015). The main roles the amino acids play in plant growth include modulation of nitrogen uptake, acting on the signaling pathway of nitrogen acquisition in roots, and increasing microbial biomass and activity (Jardin 2015).

Seaweed has been a source of organic matter and fertilizer for soil for a long time, but more recently, biostimulant effects have been recorded (Jardin 2015). When seaweed extract products are applied to soil, the polysaccharides contribute to increased water retention and soil 
aeration. The polyanionic compounds contribute to heavy metal fixation and increased cation exchange capacity (Khan et al. 2009; Jardin 2015). It has been shown that certain species of seaweed extract can increase plant resistance to biotic and abiotic stresses (Khan et al. 2009).

Hydraulic growth mediums (HGMs) are products used as a topsoil replacement. HGMs use a combination of organic matter materials and soil stabilizers along with a small amount of microbial compounds and bacteria (Erosion Control Blanket 2013; Verdyol Biotic Earth 2015). The organic matter and microbial compounds and bacteria all work towards establishing vegetation and increasing plant growth. The soil stabilizer bonds the HGM to the parent soil to increase soil structure and water infiltration (Verdyol Biotic Earth 2015).

\subsubsection{Mulch}

Mulch is a naturally degradable material that provides erosion control during the initial germination and growth of vegetation (Allen 1996). Mulch comes in many different types and each type has their unique situations for which they are best suited. Some of the most common mulching practices are straw, rolled erosion control products (RECPS), and hydraulic erosion control products (HECPs).

Loose straw is typically the least expensive mulching practice if applied correctly (Babcock and McLaughlin 2008). Straw mulch has a lifespan of approximately 3-6 months when it is anchored properly (NRCS 2012). Although straw mulch has a shorter lifespan than other mulching practices, it is typically enough time to establish vegetation (Babcock and McLaughlin 2008). Straw mulch is prone to wind erosion and must be anchored for prevention. The most common methods of anchoring are applying a chemical tackifier or crimping, but anchoring with a tackifier is the recommended method (Babcock and McLaughlin 2013).

Straw mulch can be applied to all slopes but performs best on a gentle slope (Babcock and McLaughlin 2013). A study by Benik et al. (2003) found that on a steep $\left(20^{\circ}, \sim 2.75 \mathrm{H}: 1 \mathrm{~V}\right)$ slope treated with $4,000 \mathrm{lb} / \mathrm{ac}(4,500 \mathrm{~kg} / \mathrm{ha})$ of straw mulch lost one-tenth the soil of the bare control plots. The study also found on the same slope that $7,000 \mathrm{lb} / \mathrm{ac}(7,850 \mathrm{~kg} / \mathrm{ha})$ of bonded fiber matrix (BFM) hydromulch lost one-tenth of the soil as compared to the straw mulch. A similar study by McLaughlin and Brown (2006) tested 1,960 lb/ac (2,200 kg/ha) of straw mulch and $3,000 \mathrm{lb} / \mathrm{ac}(3,360 \mathrm{~kg} / \mathrm{ha})$ of BFM hydromulch on a gentle slope $\left(2.3^{\circ}\right)$. The results showed that on average the straw mulch plots lost $714 \mathrm{lb} / \mathrm{ac}(800 \mathrm{~kg} / \mathrm{ha}$ ) while the BFM plots lost 536 $\mathrm{lb} / \mathrm{ac}(600 \mathrm{~kg} / \mathrm{ha})$ of soil. The data shows that straw mulch is not as effective as a HECP on a steep slope but is comparative on a gentle slope.

RECPs are an improved straw mulch. RECPs are made of a mat that contains straw mulch or similar products contained within a net to provide anchoring (Allen 1996). RECPs have a varying lifespan depending on the type of product applied. Single-net RECPs only have a lifespan of approximately 3-12 months while a continuous mat can have a lifespan of up to 36 months (MDEQ 2010). RECPs are superior to loose straw mulch when subject to high flow conditions such as within flow channels (Sutherland 1998). RECPs are a strong choice for 
erosion control during vegetation growth as they can be applied on almost any slope $(\leq 1 \mathrm{H}: 1 \mathrm{~V})$ (Babcock and McLaughlin 2008).

HECPs are a hydraulically applied mulch that contains naturally biodegradable fibers and one or more non-toxic additives such as soil tackifiers, soil flocculants, soil polymers, crosslinked hydro-colloidal polymers, or cross-linked tackifiers (SCDOT 2011b; Profile Products LLC 2017). HECPs are a type of mulch that can provide nutrients to the vegetation while providing erosion control. HECPs are useful for very large or steep slopes as it can be applied from a distance and requires less labor than loose straw or RECPs (Montoro et al. 2000). A unique property of HECPs is that soil amendments and seeds can be applied with the mulch (Babcock and McLaughlin 2008).

\subsubsection{Review of Current Specifications}

\subsubsection{WVDOH Section 642: Temporary Pollution Control}

WVDOH section 642 contains information for temporary pollution control on areas of a construction site that needs protection against water pollution and sediment laden water runoff. This section also contains information on how temporary seeding should be performed on areas that will not be disturbed for a period of more than 14 days. It is important to attempt to establish vegetation on all disturbed areas of soil as soon as possible to prevent sediment-laden runoff to clean water sources (WVDOH 2010).

The current specification allows for the seeding mixtures used for permanent seeding in WVDOH section 652 to be used for temporary seeding (WVDOH 2010). The current section 642 outlines its own specifications for applying lime, fertilizer, and mulch, which differ from the procedures in section 652 (WVDOH 2010).

According to WVDOH section 642, temporary seeding and mulching should be performed as often as possible on sites that have disturbed soil that is not up to grade as shown on final plans and will not be worked for the next 14 days. In addition to seeding areas every 14 days, fill slopes and waste sites shall be seeded every $10 \mathrm{ft}(3 \mathrm{~m})$ lift and cut slopes shall be seeded every $15 \mathrm{ft}$ (4.5 m) cut (WVDOH 2010). Temporary seeding should grow as quickly as possible to establish erosion control measures and thus vegetation defined as a nurse or cover crop shall be used. A nurse or cover crop is a plant that grows quickly and fosters development of other species of plants, such as common oats or cereal rye (Shepperd and Jones 1985).

\subsubsection{WVDOH Section 651: Furnishing and Placing Topsoil}

WVDOH section 651 contains information about the handling and placement of topsoil. Section 651 was analyzed because topsoil is a major component in achieving vegetative cover. The organic matter in topsoil provides nutrients such as nitrogen, phosphates, and sulfur into the soil along with having water-holding capabilities and soil stabilization properties, which increase erosion prevention (Funderburg 2001). The current specification provides a broad range of $1.5 \%-20 \%$ on acceptable organic matter with no description on how to remediate the organic matter content (WVDOH 2010). 
Topsoil is a very sensitive construction material in the way it needs to be handled and applied. The current specification provides little information on the stripping and storage of topsoil prior to cut/fill activities. Topsoil has a lower friction angle compared to other soils and is prone to slippage (GeoTechData 2013). Extra precaution is required when placing topsoil onto finished construction slopes to ensure topsoil adhering to the subsoil (Booze-Daniels et al. 2000), which is not specified in this specification.

\subsubsection{WVDOH Section 652: Seeding and Mulching}

WVDOH section 652 contains information about permanent seeding and maintenance of seeded areas. This section was the primary goal in this research to evaluate and revise as recommended. This section contains information pertaining to permanent seeding including planting dates, soil preparation, sowing seed, acceptable seed mixtures, applying mulch and fertilizer, and maintenance of seeded areas (WVDOH 2010).

The soil preparation section 652.4 contains information about how the soil to be planted in shall be remediated with soil additives such as lime and fertilizer according to soil tests, but it contains no information about how these soil tests should be conducted and how lime and fertilizer shall be applied after testing the soil. This section also contains information about scarifying the soil but no details on how and when it should be done (WVDOH 2010).

Section 652.6 contains information about applying mulch and fertilizer after seeding has occurred. Mulching procedures mentioned include straw mulch, hydraulically applied wood cellulose fiber, and wood chips. There are many more mulching procedures available that provide the same or better vegetation establishment and erosion control. The section talks about the kind of fertilizer used being of one type when many different sites and soil types should take different fertilizer types, depending on soil test data. The specification briefly mentions that agricultural granular limestone may be used to condition the soil after a pH test but makes no mention of fast-acting limestone (WVDOH 2010).

\subsubsection{WVDOH Section 715: Materials}

Section 715 contains specifications on the materials to be used to items such as limestone, fertilizers, mulch, and seed. This section was analyzed because it pertains directly to seeding and mulching. The section also contained no information about materials such as BGSs and HGMs.

\subsubsection{Other Sources of Information}

\subsubsection{Other States' Specifications and WVDEP}

Many states' specifications were analyzed during this research with some of the notable states being South Carolina, Virginia, Idaho, and Minnesota, along with the WVDEP (e.g., Table 1). State specifications were reviewed and compared to the WVDOH specifications to ensure completeness in updating the methods. Many states change their specifications every few years to keep up with new products and methods (e.g., Table 1). 
South Carolina Division of Transportation (SCDOT) was the most notable specification that was analyzed. SCDOT gave framework for HECPS, BGSs, and fast-acting limestone. SCDOT (2007) last updated their full specifications in 2007, but the sections of seeding and HECPs were last updated in 2011 (SCDOT 2011a, 2011b).

After the states were analyzed, comparison could be built to identify the most common BMPs. Table 2 shows a comparison of BMPs found in West Virginia and surrounding states. Although no current states use a HGM in their specifications, South Carolina recently completed a case study with the use of HGMs (Profile Products LLC 2011). Some states analyzed still use a system of set rates for soil amendments instead of determining amendment rates with a soil test. West Virginia is also one of the few states that do not use a RECP in their specifications as a mulching practice.

Table 2: Comparison of state BMPs

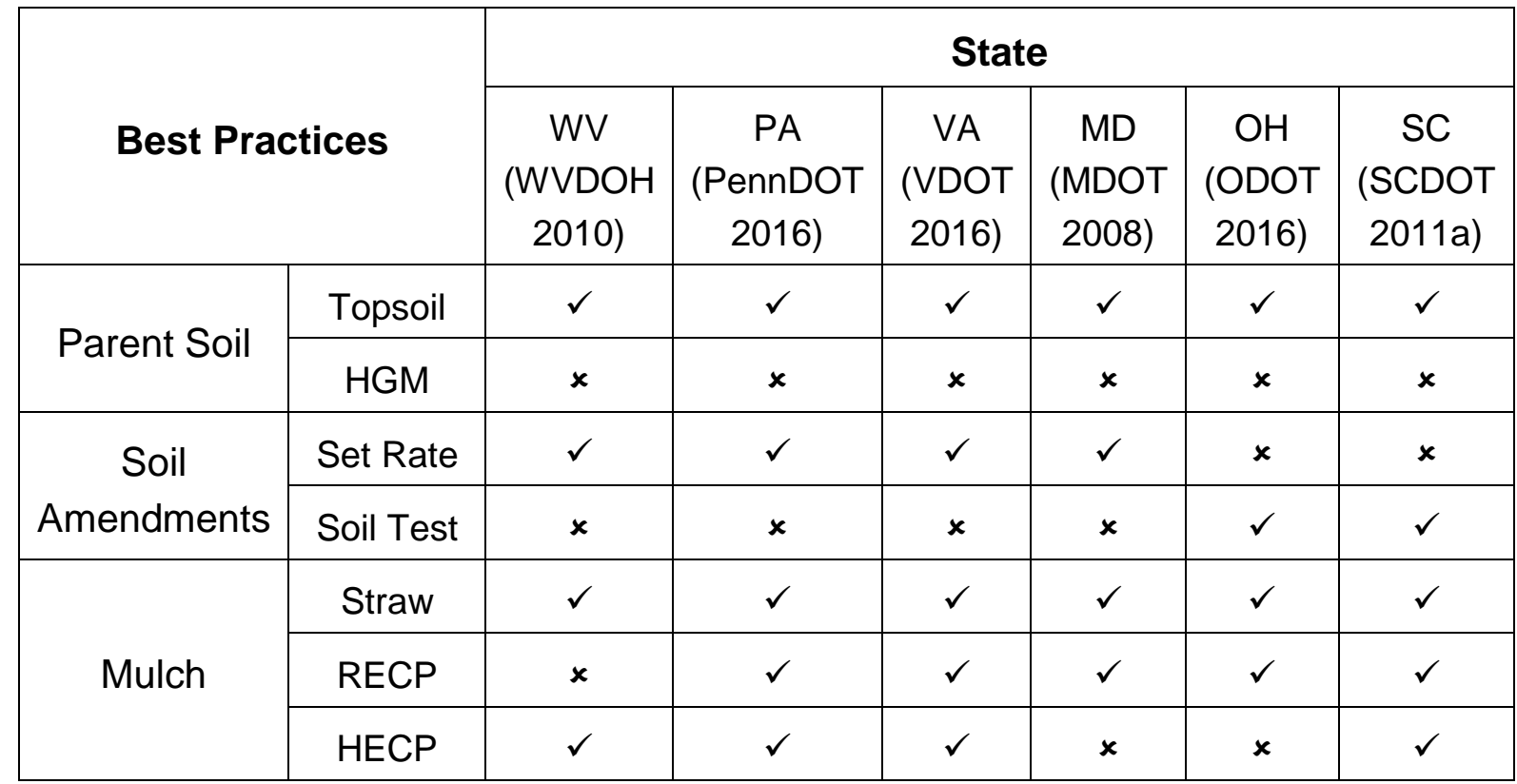

Note: $\checkmark=$ included in source specification, $x=$ not included in source specification

\subsection{Results}

After applying the above methods to the WVDOH specifications, revised specifications were created. The revised specifications can be found in Appendix A: Revised WVDOH Section 642, Appendix B: Revised WVDOH Section 651, Appendix C: Revised WVDOH Section 652, and Appendix D: Revised WVDOH Section 715. Section 715 is large section that contains specifications about many different materials used in highway construction. Only the sections modified by this research are included in Appendix D. The highlighted sections of each specification shows the changes that were made. 


\subsubsection{WVDOH Section 642: Temporary Pollution Control}

Section 642 was revised in order to create an understanding between the difference of permanent seeding and temporary seeding. The current specification used the same permanent seed mixtures as outlined in Section 652: Seeding and Mulching as temporary seeding mixtures. This created confusion between contractors and the WVDOH. This also increased cost of seeding on sites by using more expensive seeds recommended for permanent seeding as temporary seeds.

The specification was revised to consist of only temporary seed mixtures, common oats and cereal rye. These seed mixtures are currently used as the nurse crop for the permanent seed mixtures in Section 652. A nurse crop was chosen for the temporary seed mixture because of its ability to grow quickly (DeBoyle and Winokur 1985). The revised specification can be found in Appendix A.

\subsubsection{WVDOH Section 651: Furnishing and Placing Topsoil}

Minor revisions were suggested to Section 651. The topsoil section was a supplementary item in the review of Section 652: Seeding and Mulching. Some of the substantial restructure changes can be found in Table 3 and the changes discussed in the following paragraphs. The revised Section 651 specification can be found in the attached Appendix B.

Current WVDOH specifications allow minimum organic levels to be as low as $1.5 \%$ (WVDOH 2010). Organic matter typically exists in soil at levels between 1\% and 5\% (DeGomez et al. 2015). JT Talley (personal communication, July 7, 2016) suggested that organic matter of at least 3\% was optimal to achieve seed germination. Fenton et al. (2008) also recommends that organic matter be at least $3 \%$ of the soil by weight. Topsoil performs best with high levels of organic matter so a cap should not be included (DeGomez et al. 2015).

Vegetation that is not removed prior to topsoil stripping and stockpiling can degrade the quality of topsoil (Duralie Coal Pty Ltd 2003). In order to remove all vegetation biomass, Donald Williams (personal communication, July 7,2016 ) mentioned that removing the root mass when stripping vegetation should be included for clarity. It is important to strip all vegetation from topsoil before stockpiling to prevent the purity of the topsoil from degrading. Strohmayer (1999) suggests that stockpiling topsoil is the most effective option to store topsoil without degrading the quality. This can also aid in the placement of topsoil. When placing topsoil, material 2 inches $(50 \mathrm{~mm})$ or greater shall be removed in all areas and material 1 inch $(25 \mathrm{~mm})$ or greater shall be removed in areas that are to be planted with mowable areas mixture (WVDOH 2010).

Topsoil shall be placed at sufficient depths that provide for vegetative cover but shall not be placed at depths that permit erosion (Ferris 2006). Currently, no specifications were present for depths of topsoil applied (WVDOH 2010). A minimum depth of 6 inches (150 mm) was applied with a minimum compacted depth of 4 inches $(100 \mathrm{~mm})$ to ensure enough topsoil is placed to facilitate vegetation growth. 
Table 3: Section 651 specification change summary

\begin{tabular}{|l|l|l|}
\hline \multicolumn{1}{|c|}{$\begin{array}{c}\text { Current WVDOH } \\
\text { Specification }\end{array}$} & \multicolumn{1}{c|}{$\begin{array}{c}\text { Revised WVDOH } \\
\text { Specification }\end{array}$} & \multicolumn{1}{c|}{ Reference } \\
\hline $\begin{array}{l}\text { "topsoil shall contain organic } \\
\text { matter in the range of 1.5\% to } \\
20 \% . "\end{array}$ & $\begin{array}{l}\text { "topsoil shall contain at least } \\
\text { 3\% organic matter." }\end{array}$ & $\begin{array}{l}\text { (JT Talley, personal } \\
\text { communication, July 7, } \\
2016)\end{array}$ \\
\hline $\begin{array}{l}\text { "Contractor shall remove all } \\
\text { heavy grass, weeds, or other } \\
\text { vegetation in the areas before } \\
\text { stripping." }\end{array}$ & $\begin{array}{l}\text { "Contractor shall remove all } \\
\text { heavy grass, weeds, or other } \\
\text { vegetation, including root mass, } \\
\text { in the areas before stripping." }\end{array}$ & $\begin{array}{l}\text { (Donald Williams, } \\
\text { personal communitcation } \\
\text { July 2016) }\end{array}$ \\
\hline $\begin{array}{l}\text { "Topsoil shall not be spread to } \\
\text { a greater depth than that } \\
\text { required to make the work } \\
\text { conform to the natural terrain" }\end{array}$ & $\begin{array}{l}\text { "Topsoil shall be applied at a } \\
\text { minimum depth of 6 inches." }\end{array}$ & (ODOT 2016) \\
\hline
\end{tabular}

Additional revisions to section 651 include:

1. Topsoil containing less than $3 \%$ organic matter shall be conditioned with biological growth stimulants (JT Talley, personal communication, July 7, 2016).

2. Topsoil may not be applied to slopes steeper than $2 \mathrm{H}: 1 \mathrm{~V}$ (Horizontal:Vertical) (GeoTechData 2013).

3. All slopes less than or equal to $2 \mathrm{H}: 1 \mathrm{~V}$ that do not meet organic matter of at least $3 \%$ require the application of topsoil (WVDOH 2010).

4. An approved hydraulic growth medium may be used in replace of topsoil (SCDOT 2011a).

5. Prior to application, fertilizer, lime, and other soil amendments shall be added to the topsoil according to the soil analysis (SCDOT 2011a).

A previous section of this research performed by Hopkinson et al. (2016) found a positive correlation between percent cover and percent organic matter found in topsoil. Topsoil containing less than the recommended 3\% organic matter shall be conditioned with BGSs. BGSs contain humic acids and bacteria such as mycorrhizae. These substances greatly increases the organic matter and biological activity in soil to provide for more favorable conditions for plant growth (Sultan 2016). This was recommended as an alternative by JT Talley (personal communication, July 7,2016 ) instead of bringing in new topsoil that could meet the organic matter specification in order to reduce costs.

According to GeoTechData (2013) soil containing high amounts of organic matter have a lower friction angle than most other soils. This friction angle corresponds with a maximum slope of $2 \mathrm{H}: 1 \mathrm{~V}$. Thus, topsoil shall be placed at no greater than a $2 \mathrm{H}: 1 \mathrm{~V}$ slope and must be placed on all slopes 2H:1V or flatter. Salon and Miller (2012) and Booze-Daniels et al. (2000) agree in 
order to reduce erosion and sediment loses, topsoil should be placed at a maximum of $2 \mathrm{H}: 1 \mathrm{~V}$ slope. This was added to the specifications because there was no limit on what slope topsoil can be placed (WVDOH 2010). Specifications on HGMs also correspond to a maximum slope of 2H:1V (Erosion Control Blanket 2013). More information on HGMs can be found in 2.4.4 WVDOH Section 715: Materials.

\subsubsection{WVDOH Section 652: Seeding and Mulching}

Section 652, as expected, contained a large number of suggested revisions. Table 4 shows a summary of the major suggestions to the specification. Justification of each suggestion can be found in the following paragraphs. The revised section 652 can be found in the attached Appendix C.

Of all the processes for anchoring straw mulch to soil, using a non-toxic chemical tackifier has been shown to provide the best results (Kay 1980; Brooks 1993; Babcock and McLaughlin 2013). Asphalt was removed as an acceptable method for anchoring straw mulch. In a study by Dudeck et al. (1970) that evaluated different mulching techniques, it was found that asphalt anchored products performed the worst. In a similar study by Burroughs and King (1989) it was found that hydraulic mulch was not effective unless used with a chemical tackifier. The specifications were rewritten to include non-toxic chemical binders for anchoring straw mulch that completely photo-degrades or biodegrades.

The current specification only calls for agricultural limestone to be added following a soil $\mathrm{pH}$ test. Another important type of limestone is dry or liquid fast-acting limestone. Fast-acting limestone provides almost instantaneous $\mathrm{pH}$ remediation in soil (SCDOT 2011a). Fertilizer is called to be added during any seeding procedure but only qualifies one type of fertilizer. Many different types of soils require different liming procedures and types of fertilizer in order to effectively remediate the soil. In a study performed by Dong et al. (2012) that evaluated 4 different types of fertilizer on a certain soil, it was found that each type of fertilizer had a different impact on each result of $\mathrm{pH}$, soil organic carbon, total nitrogen, carbon/nitrogen ratio, and available nutrients.

The definition of a stand was unclear and thus was the definition of the closure of projects. This was revised to conform to WVDEP's Erosion and Sediment Control BMP Manual (2006). The BMP Manual defines an area failing to establish $70 \%$ of cover over the entire site as an incomplete project under WVDEP's NPDES permit (WVDEP 2006). In the state of West Virginia, a NPDES permit is required for all sites containing construction areas greater than 3 acres of disturbance. A similar permit, Notice of Intent (NOI), is required by the WVDEP for sites with areas of disturbance between 1-3 acres. Both the NPDES and NOI contain the $70 \%$ of coverage over the entire site before completion of the site requirement. No permit is required by the WVDEP for sites under 1 acre of disturbance (WVDEP 2006). 
Table 4: Section 652 specification change summary

\begin{tabular}{|l|l|l|}
\hline \multicolumn{1}{|c|}{$\begin{array}{c}\text { Current WVDOH } \\
\text { Specification }\end{array}$} & \multicolumn{1}{c|}{$\begin{array}{c}\text { Revised WVDOH } \\
\text { Specification }\end{array}$} & \multicolumn{1}{c|}{ References } \\
\hline $\begin{array}{l}\text { "Asphalt for anchoring mulch } \\
\text { shall be of commercial } \\
\text { grade." }\end{array}$ & $\begin{array}{l}\text { "Tackifier or chemical mulch } \\
\text { binders shall be of } \\
\text { commercial grade" }\end{array}$ & (SCDOT 2011a) \\
\hline $\begin{array}{l}\text { "The application rate for } \\
\text { determined by a pH test" }\end{array}$ & $\begin{array}{l}\text { "The application rate for } \\
\text { limestone, fertilizer, and other } \\
\text { soil amendments will be } \\
\text { determined by a soil test" }\end{array}$ & (SCDOT 2011a) \\
\hline $\begin{array}{l}\text { "Any area failing to establish } \\
\text { a stand due to weather } \\
\text { conditions or adverse soil } \\
\text { conditions" }\end{array}$ & $\begin{array}{l}\text { "Any area failing to establish } \\
\text { 70\% of cover by area over } \\
\text { 100\% of the site due to any } \\
\text { reason" }\end{array}$ & (WVDEP 2006) \\
\hline $\begin{array}{l}\text { "Straw mulch may be } \\
\text { anchored with 100 gallons of } \\
\text { asphalt" }\end{array}$ & $\begin{array}{l}\text { "Straw mulch must be } \\
\text { anchored with a non-toxic } \\
\text { tackifier or binder" }\end{array}$ & (PennDOT 2016) \\
\hline $\begin{array}{l}\text { "The kind and amount of } \\
\text { fertilizer per acre (ha) shall } \\
\text { ratio" }\end{array}$ & $\begin{array}{l}\text { "The kind and amount of } \\
\text { fertilizer per acre (ha) shall } \\
\text { be determined by the soil } \\
\text { analysis." }\end{array}$ & (SCODT 2011a) \\
\hline
\end{tabular}

Major additions to section 652 include:

1. Complete soil test for planting soil (Section 652.4.1).

2. Rolled erosion control products (RECPs) (Section 652.7.4).

3. Hydraulic erosion control products (HECPs) (Section 652.7.2).

4. Agricultural granular and fast-acting limestone (Section 652.7.6).

5. Re-Application and spot application (Section 652.8.2).

The requirements for a soil test have been changed to increase the quality of soil. The current specifications only required the $\mathrm{pH}$ of the soil to be tested. The soil test in the new specifications requires that the $\mathrm{pH}$, buffer $\mathrm{pH}$, fertilizer requirements, lime requirements, and other BGS requirements be reported by a soil test. These requirements recommend the right amount and type of limestone and fertilizer in order to balance the $\mathrm{pH}$ and nutrients in the soil.

The soil sampling procedure was modified from SCDOT's "Supplemental Technical Specification for Seeding" (2011a) and modified further by communication with industry professionals. The procedure creates a composite soil sample across a 1 to 5 acre distinguishable representative area. If a project contains more than 5 acres then multiple 
distinguishable representative areas will be established. Areas under 1 acre are not required to be tested but is recommended for optimal results on a site. The distinguishable representative area is defined by changes in soil such as texture, color, or consistency.

RECPs were implemented into the new specification to assist in erosion control during seed germination. RECPS are a close alternative to straw mulch and tackifier as the products are typically comprised of straw mulch woven in between a natural or polymer fiber net. The anchoring of RECPs allows for stronger erosion control than straw mulch and tackifier (Sutherland 1998). RECPs can be applied to steeper slopes than straw mulch and for longer continuous lengths (Babcock and McLaughlin 2008).

HECPs were a major addition to the new specifications. HECPs were adopted from SCDOT (2011b), ECTC (2014), and Profile Products LLC (2015) specifications. HECPs are a hydraulically applied mulch that protects the soil from eroding during seed germination (SCDOT 2011b; Profile Products LLC 2017). HECPs also provide stability by bonding with the soil after application (Babcock and McLaughlin 2013).

Three different types of HECPs were specified to be used according to the steepness of slope they are applied to, as shown in Table 5. HECP Type 1 is a stabilized mulch matrix (SMM) and contains a minimum of $70 \%$ wood fiber or natural fibers and a non-toxic tackifier or binder. HECP Type 2 is a bonded fiber matrix (BFM) that contains a minimum of $70 \%$ non-toxic defibrated organic fibers. HECP Type 3 is a fiber reinforced matrix (FRM) that consists of a minimum of $70 \%$ defibrated organic fibers and a minimum of $5 \%$ biodegradable interlocking fibers. HECP types 2 and 3 are required to contain at least one of the following additives:

1. Soil tackifiers.

2. Soil flocculants.

3. Soil polymers.

4. Cross-linked hydro-colloidal polymers.

5. Cross-linked tackifiers.

Table 5: Minimum mulch application rates (SCDOT 2011b)

\begin{tabular}{|l|l|l|}
\hline Mulch & Applicable Slopes & $\begin{array}{l}\text { Minimum Application Rate } \\
\text { (lb/acre - dry) (kg/ha) }\end{array}$ \\
\hline HECP Type 1 & $\leq 4 \mathrm{H}: 1 \mathrm{~V}$ & $2,500(2,800)$ \\
\hline HECP Type 2 & $4 \mathrm{H}: 1 \mathrm{~V}<\mathrm{S} \leq 2 \mathrm{H}: 1 \mathrm{~V}$ & $3,000(3,359)$ \\
\hline HECP Type 3 & $2 \mathrm{H}: 1 \mathrm{~V}<\mathrm{S} \leq 0.5 \mathrm{H}: 1 \mathrm{~V}$ & $4,000(4,479)$ \\
\hline
\end{tabular}

The rates in Table 5 are minimum rates as adopted from SCDOT (2011b). The new specification requires that HECPs be applied at the specified rate by the manufacturer while following the minimum standard listed above. Lime, fertilizer, seed, inoculant, and other soil amendments can be mixed with the HECP and applied during the same step to minimize the amount of work performed at the construction site (Babcock and McLaughlin 2008). 
There are two types of limestone that can be applied to soil for $\mathrm{pH}$ remediation. The current specification only uses agricultural granular limestone based on results from a pH test. Liquid or dry fast-acting limestone is used for immediate $\mathrm{pH}$ stabilization and is useful for very acidic or time sensitive sites (SCDOT 2011a). Agricultural granular limestone releases slowly into the soil providing a slower but longer $\mathrm{pH}$ remediation and is useful for keeping the $\mathrm{pH}$ in an acceptable range during plant growth. The results of the soil test will require the type of lime, or both, and the amount to be used.

\subsubsection{WVDOH Section 715: Materials}

The main reason for Section 715 is to define material properties for all construction materials used in a project. The main revisions to Section 715 were additions of new BMP properties. The revised Section 715 can be found in the attached Appendix D: Revised WVDOH Section 715. The main sections added include:

1. Fast-acting limestone (Section 715.25.2).

2. Hydraulic erosion control products (Section 715.27.1.2).

3. Biological growth stimulants (Section 715.30).

4. Hydraulic growth mediums (Section 715.31).

BGSs were added to the specification as an alternative to bringing in topsoil to a site that meets organic matter specification, as this can be very expensive. BGSs main purpose is to add organic matter to the soil along with other nutrients to assist in plant growth such as beneficial fungi and bacteria (Jardin 2015). This is to be used when existing topsoil on a construction site does not meet the requirement of at least $3 \%$ organic matter.

Topsoil replacement products, such as HGMs, are shown to provide more organic matter in the soil and maintain higher levels of organic matter for a longer period (Olsen and Jones 1988). HGMs are to be used on sites that are void of existing topsoil or the quantity of topsoil is less than the topsoil needed to seed the site. HGMs are similar to BGSs with the exception that HGMs contain a soil-stabilizing product to bond to the parent soil (Verdyol Biotic Earth 2015).

\subsection{Conclusions}

The purpose of revising WVDOH's specifications on seeding and mulching was to incorporate new BMPs in order to improve the quality of vegetation establishment following highway construction. Vegetation cover is the most practical way to reduce erosion on construction sites. Proper vegetation cover is difficult to establish and maintain without proper methods of applying seed. Specifications need to be in a dynamic state to conform to current BMPs in order to be most effective. Many states update their specifications often to accomplish this.

The specification for West Virginia was reviewed to determine the limitations in accordance with new BMPs. Additional specifications from states near West Virginia with similar 
climates were analyzed for their BMPs. The BMPs were researched and the best options were added to the specification to improve the quality of vegetation around West Virginia.

Topsoil, soil testing and amendments, and mulch, or the three main BMPs identified in this research, all contain many parts that contribute different properties to vegetation growth. Each BMP is essential for establishing proper vegetation growth. Topsoil provides a medium from which vegetation obtains nutrients and water. Soil testing provides the optimal amount of amendments to be added to the soil to provide for the optimal nutrients. Mulch protects the soil from eroding before vegetation is established and can also provide some extra nutrients to the seeds to assist in germination.

The BMPs were added to four different sections in the WVDOH specifications: Section 642: Temporary Pollution Control, Section 651: Furnishing and Placing Topsoil, Section 652: Seeding and Mulching, and Section 715: Materials. All of the sections were modified to reflect the changes to existing BMPs within the specifications or to show the new additions to the specification.

The revised specifications should improve the quality of highway vegetation around the state of West Virginia. The revised specifications can also be used as a template for other entities as they contain the most recent BMPs in the seeding and mulching industry. It is recommended that the specifications are updated every few years as new BMPs are produced or as old BMPs are updated. 


\section{Ch. 3 Materials Estimating Tool}

\subsection{Introduction}

The overall scope of objective 2 was to create a tool to assist in the cost calculation of materials in the revised WVDOH specifications. The tool is to be used on a construction site that is ready for the initial permanent seeding. The tool guides the user to a cost effective solution for a construction site while following the revised specifications.

The tool is developed to be utilized by engineers within the WVDOH. The tool can be used in both pre-bid and final cost calculation applications. The pre-bid application will assist in determining the most accurate price for a new construction project in respect to the seeding and mulching. After a project is underway and more knowledge about the site is known, such as a soil test that identifies the soil pH, nutrients, and composition of the soil, the tool can be used to find the final price of the seeding and mulching application.

This tool was tested by using data from existing sites to compare results and determine effectiveness. The three sites used for testing are from Hopkinson et al. (2016). The three sites are Route 47 Interchange, Route 279 Roadside, and Corridor $\mathrm{H}$. These areas all have two or more different areas that contain different slopes or types of soil. This allows the user to test the programs ability to calculate results from multiple areas within the same site and create a total cost analysis for a construction site.

The specific objectives of this work include the following:

1. create a tool to assist in the calculation of permanent seeding and mulching with the revised specifications,

2. use the tool to assist a user into choosing the optimal method of seeding and mulching in terms of usefulness and cost,

3. create an output that can be used to calculate pre-bid and final cost calculations, and

4. test the tool with data from field sites and compare to known results.

\section{2: Methods}

The tool was developed in Microsoft Excel so it can be compatible with many users. The tool utilizes multiple worksheets in Excel to:

1. instruct the user on how to use the program,

2. take inputs,

3. perform calculations, and

4. report information.

The tool was created with eight worksheets. Four of the worksheets are available to the user, and the other four worksheets are hidden. The hidden worksheets perform cost calculations that are then shown on the output worksheet. The worksheets include:

1. Instructions, 
2. Input Worksheet,

3. Output Worksheet,

4. Prices,

5. Cost-Calculation-Seed (hidden),

6. Cost-Calculation-Mulch (hidden),

7. Cost-Calculation-Soil Amendment (hidden), and

8. Cost-Calculation-Soil Test (hidden).

\subsection{1: Tool Calibration}

Material prices were needed to calculate the program. Some of the prices used in the development of this tool were found from the WVDOH Average Unit Bid Prices chart (WVDOH 2016). This chart shows the average price of materials in the current specifications that each district in the state paid each year. The prices chosen from this chart include straw mulch, 1020-10 fertilizer, agricultural limestone, and topsoil. These materials were adapted from the original specification into the revised specification.

Additional prices were found from various sources. The prices of other types of fertilizer in the program, as shown by Table 6, were obtained from Flynn (2014). The average of price of the fertilizers from the years 2010-2014 were used to calibrate the program. These prices were obtained from the averages in the states of Colorado, New Mexico, Montana, and Wyoming. These prices were used to calibrate the tool and ensure the tool ran correctly. When the tool is used for professional purposes, the user should research different vendors in the specific region that the construction site is located to find the optimal prices.

Table 6: Average Price of Common Fertilizers

\begin{tabular}{|l|c|c|}
\hline Common Name of Fertilizer & Formula (N-P-K) & Price/ton (Flynn 2014) \\
\hline Ammonium Nitrate & $33.5-0-0$ & $\$ 503$ \\
\hline Ammonium Phosphate & $10-34-0$ & $\$ 650$ \\
\hline Ammonium Sulfate & $21-0-0$ & $\$ 456$ \\
\hline Ammonium Phosphate Sulfate & $16-20-0$ & $\$ 527$ \\
\hline Anhydrous Ammonia & $82-0-0$ & $\$ 697$ \\
\hline Diammonium Phosphate & $18-46-0$ & $\$ 675$ \\
\hline Monoammonium Phosphate & $11-52-0$ & $\$ 652$ \\
\hline Muriate of Potash & $0-0-60$ & $\$ 630$ \\
\hline Triple Superphosphate & $0-46-0$ & $\$ 996$ \\
\hline Urea & $46-0-0$ & $\$ 567$ \\
\hline Urea Ammonium Nitrate & $32-0-0$ & $\$ 497$ \\
\hline
\end{tabular}

The prices of HECP mulch products were adapted from SCDOT (2017) bid tabulations. SCDOT (2017) bid tabulations are publically released documents that show how much a contractor bids on individual items on a design project. The bid tabulations were used because the HECP section was adapted from SCDOT (2011b). West Virginia currently does not use a 
similar product to the new HECP products in the revised specifications. The documents were analyzed and the prices for the three different types of HECP products were averaged. These numbers were then added to the tool for calibration. This information assists in calculating the average bid price of HECP products that could be used on a project. Cost information should be updated with the most accurate information, according to the current market value and availability for the region, with each application of the tool.

The prices of seeds were formed from the Ernst Conservation Seeds Wholesale Price List (Ernst Seeds 2017). The price list contains all of the seeds that are in the experimental seed mixtures. The experimental seed mixtures were created with reference to the Ernst Conservation Seed Catalog among other sources (Hilvers et al. 2017). The Ernst Seeds price list is an average price for the seeds, but the seed prices are subject to change depending on availability and demand (Ernst Seeds 2017). When using the tool for price estimation, the current updated prices of seeds should be used from the current catalog or elsewhere if seed is bought from a different source.

\subsubsection{Input}

The program takes many different inputs from the user to calculate the recommended rates for seeding and mulching and the associated cost estimate for a construction site. The inputs are created separately for each area in a construction site. This section goes over the different inputs that the program can take and how they should be used.

\subsubsection{1: Primary Inputs}

Major construction areas may have multiple areas with various requirements for seeding and mulching. The tool allows for multiple areas within a single construction site to be entered. To accomplish this, the user enters an integer number from 1 to 10 according to the number of planting areas that are on a construction site ready for permanent seeding (Figure 1). The planting areas are areas that contain different seed mixtures, different slopes, different intended mulches, or different soil test results. If a user tries to enter a number different from an integer between 1 and 10, the program shows an error that prompts the user to enter a correct value. For sites that have more than 10 different planting areas, multiple programs will be needed. This is to keep each iteration of the program concise for the user.

Once the user chooses a set number of planting areas, the program automatically populates the input sheet with input tables as shown in Figure 1, according to the number of chosen planting areas. The input information, as shown in Figure 1, is repeated when multiple planting areas are necessary. For example, if the user inputs 4 different planting areas, 4 different input tables will populate labeled Area 1, Area 2, Area 3, and Area 4, respectively. 


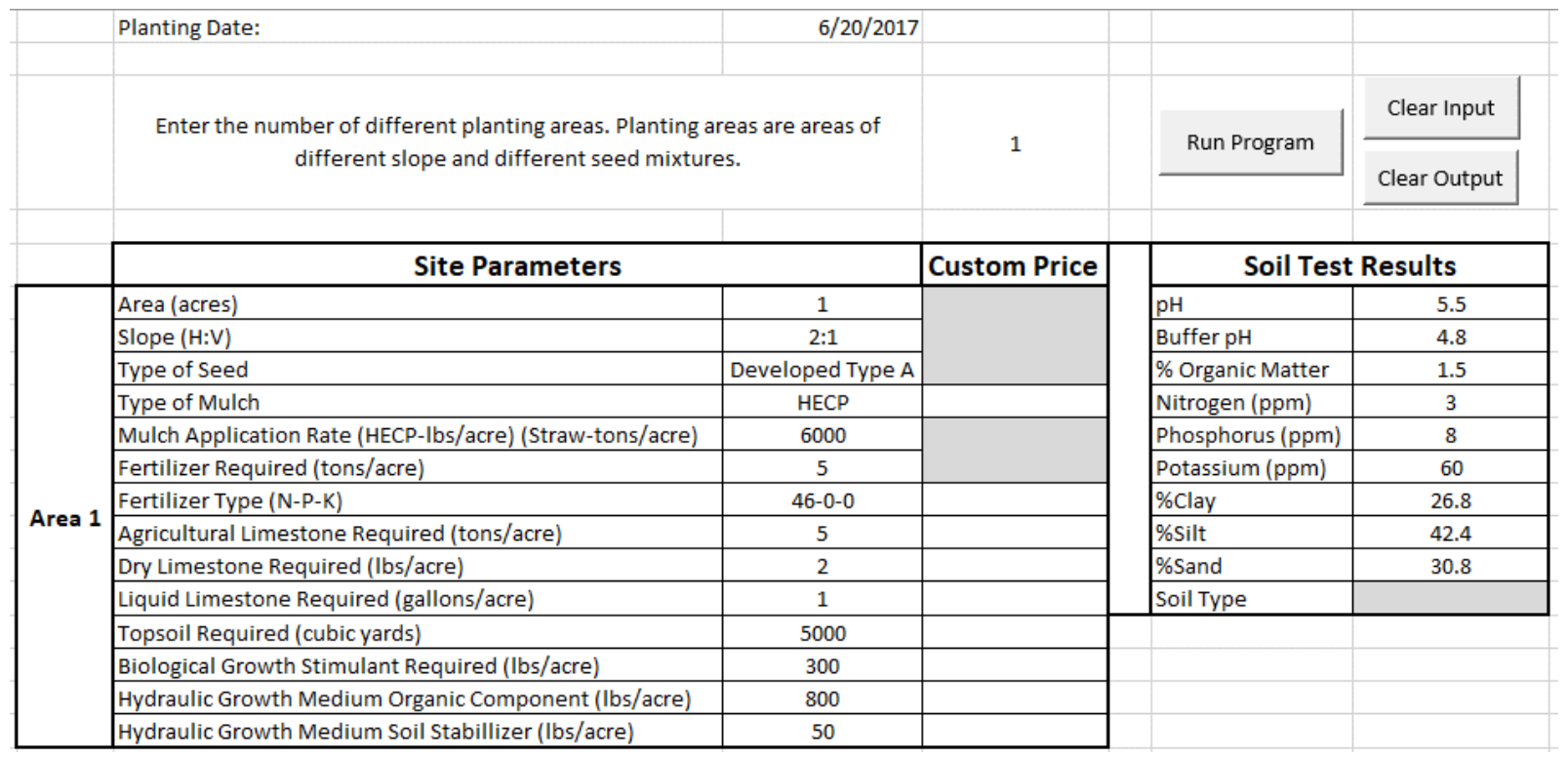

Figure 1: Input table for Area 1

The minimum information for the program to run correctly include the area, slope, type of seed, and type of mulch. The program utilizes data validation so it only accepts certain values in each input box to minimize error and increase ease of use. The slope input only accepts values as shown in Table 7 under the slope category. The user may select slope values in $0.5 \mathrm{H}: 1 \mathrm{~V}$ increments within a range of $0.5 \mathrm{H}: 1 \mathrm{~V}$ to $5 \mathrm{H}: 1 \mathrm{~V}$. Rounding to the next highest slope is necessary by the user. The user should round to the next highest slope value in order to be conservative and provide the construction site with the best possible results. Slope values past $5 \mathrm{H}: 1 \mathrm{~V}$ are considered flat and the "Flat" term should be used in the slope dropdown menu (Keller and Sherar 2003, Wilkins and Bennett 2017).

The type of seed and mulch inputs correspond with the revised specifications. The options for these inputs can be found in Table 7. These inputs are in the program as a dropdown list within each input cell. This allows the user to pick a type of seed or mulch for the site without question. The list eliminates error in the program by only taking specific input that the program can recognize. The program also has an input for the intended planting date of the construction site (Figure 1). This allows the program to compare the recommended planting dates of the seed type selected. If the seed type selected is outside the intended planting date entered then the program will alert the user. 
Table 7: Options for slope, type of seed, and type of mulch as drop down options in tool

\begin{tabular}{|c|c|c|}
\hline Slope & Type of Seed & Type of Mulch \\
\hline $0.5 \mathrm{H}: 1 \mathrm{~V}$ & Developed Type A & HECP \\
\hline $1 \mathrm{H}: 1 \mathrm{~V}$ & Developed Type B & RECP \\
\hline $1.5 \mathrm{H}: 1 \mathrm{~V}$ & Developed Type C & Straw \\
\hline $2 \mathrm{H}: 1 \mathrm{~V}$ & Developed Type E & \\
\hline $2.5 \mathrm{H}: 1 \mathrm{~V}$ & & \\
\hline $3 \mathrm{H}: 1 \mathrm{~V}$ & & \\
\hline $3.5 \mathrm{H}: 1 \mathrm{~V}$ & & \\
\hline $4 \mathrm{H}: 1 \mathrm{~V}$ & & \\
\hline $4.5 \mathrm{H}: 1 \mathrm{~V}$ & & \\
\hline $5 \mathrm{H}: 1 \mathrm{~V}$ & & \\
\hline Flat & & \\
\hline
\end{tabular}

Once the primary inputs of area, slope, type of seed, and type of mulch are entered into the program, additional information can be entered to assist in cost estimate calculations. For example, an option is implemented to override the mulch application rate for each individual area. This allows for a higher mulch application rate on some areas that may be specified by design plans. The override only allows for a higher mulch application rate. If a lower rate than the minimum specified by the specification is entered, the minimum rate in the revised specifications will be used.

The program also allows an override price to be entered in the mulch application section for each area. This is implemented if a known price for mulch application is for a certain area, such as if a higher application rate of mulch is specified that requires a special price for application.

The tool only requires a few primary inputs to run, but additional information regarding soil amendments can be added if the information is available. The following two sections will outline the secondary inputs of soil amendments and soil test results for the program.

\subsubsection{2: Soil Amendments}

The program takes inputs for each of the soil amendments in the revised specifications; fertilizer, agricultural granular limestone, dry limestone, liquid limestone, topsoil, biological growth stimulants (BGSs), and hydraulic growth mediums (HGMs). These inputs are used if a known application rate has been determined by recommendations from a soil test. Each of these options allows for a custom application rate and override price to be entered. 
Fertilizer is the unique soil amendment in the program as there are many different kinds of fertilizer. The input box for fertilizer only allows input of fertilizer in the form of nitrogenphosphorus-potassium (NN-PP-KK). If a value is entered into the input that is not in that format, the program requests a correct form of fertilizer to continue with calculations. The program has a predefined list of fertilizers that compares to the inputted fertilizer. If a match is found, the program can calculate the cost of applying that type of fertilizer to the area. If a match cannot be found, the program will look if an override price was entered and if not, an error is printed onto the output sheet and manual price calculations will need to be performed once the price of the fertilizer is discovered.

The program takes inputs for the application rates and override prices for each soil amendment that is populated in the input table and calculates the cost estimate of using the materials on each area. Although the program accepts inputs for all materials and will calculate a cost estimate, some materials should not be used on the same area. For example, topsoil and HGMs should not be applied to the same area on a site and the cheaper of the two materials should be used. Another example is the use of BGSs and HGMs should not be used on the same area. A HGM is composed of an organic matter component, which is very similar to a BGS.

\subsubsection{3: Soil Test Results}

The soil test results input box is designed to create application rates for an area depending on the soil conditions as reported by a soil test. This section is designed for soil test results that do not provide soil amendment recommendations or to double check soil test recommendations for soil amendments. The soil amendment application rates that can be calculated from the soil test input section are fertilizer, agricultural granular lime, and HGMs.

The soil $\mathrm{pH}$ and buffer $\mathrm{pH}$ inputs calculate the amount of lime that is required for the soil to achieve the optimal $\mathrm{pH}$ ranges for each seed mixture. Table 8 shows the optimal $\mathrm{pH}$ levels for each seed mixture. The program uses the soil $\mathrm{pH}$ and buffer $\mathrm{pH}$ with a chart from Maguire and Heckendorn (2017) to calculate the amount of lime that is required for the site. The chart ranges in buffer $\mathrm{pH}$ from 4.0 to 6.6 while the $\mathrm{pH}$ values are $5.2,5.8,6.2,6.5$, and 6.8. The program uses 6.5 as the optimal $\mathrm{pH}$ for seed mixtures $\mathrm{A}, \mathrm{B}$, and $\mathrm{C}$ while a value of 6.8 is used for seed mixture $\mathrm{E}$. If the inputted soil $\mathrm{pH}$ is below the optimal $\mathrm{pH}$ for the chosen seed mixture, then the program determines the lime rate from the buffer $\mathrm{pH}$. If the buffer $\mathrm{pH}$ is not in the range of 4.06.6 then the program prints an error onto the output sheet stating that the lime rate cannot be calculated. 
Table 8: Seed mixtures optimal pH range

\begin{tabular}{|c|c|}
\hline Seed Mixture & Optimal pH Range \\
\hline Developed Type A & $6.5 \pm 1.0$ \\
\hline Developed Type B & $6.5 \pm 0.5$ \\
\hline Developed Type C & $6.6 \pm 1.4$ \\
\hline Developed Type E & $6.8 \pm 0.5$ \\
\hline
\end{tabular}

The amount of fertilizer is calculated by the amount of nutrients that are calculated by a soil test for a given soil area. The main nutrients found in soil are nitrogen, phosphorus, and potassium. Depending on the crop, different optimal levels of nutrients are required for soils (McKenzie 1998, Buchholz et al. 2004, Maguire and Heckendorn 2017). According to Maguire and Heckendorn (2017), the optimal levels of nitrogen, phosphorus, and potassium in soil for an erosion control seed mixture are $50.0 \mathrm{lb} / \mathrm{acre}$ (56.0 kg/ha), $90.0 \mathrm{lb} / \mathrm{acre}(100.9 \mathrm{~kg} / \mathrm{ha})$, and 60.0 $\mathrm{lb} /$ acre $(67.3 \mathrm{~kg} / \mathrm{ha})$, respectively.

The program calculates a type of fertilizer from the current nutrient levels in the soil as determined by a soil test. Maguire and Heckendorn (2017) recommend a rate of $50.0 \mathrm{lbs} / \mathrm{acre}$ $(56.0 \mathrm{~kg} / \mathrm{ha})$ of nitrogen to be added to any area that is to be planted with a permanent erosion control mixture. This rate is recommended regardless of the current levels of nitrogen in the soil. The levels of nitrogen fluctuate in soil with moisture content, soil temperature, and other biological factors (Fulton 2010). This allows for the nitrogen levels in soil to fluctuate over the course of a single day, making it difficult to recommend certain rates for nitrogen application (Fulton 2010, Maguire and Heckendorn 2017).

The levels of phosphorus and potassium in the soil greatly influence the rates of phosphorus and potassium in fertilizer that should be applied to an area to achieve optimal nutrient levels. Maguire and Heckendorn (2017) developed a system that categorizes the amount of nutrients in the soil into low, medium, high, and very high levels. Depending on the level of the nutrient in the soil, different rates of nutrients should be added to the soil to achieve the optimal nutrient levels for vegetation growth.

The program calculates a type of fertilizer by combining the recommended rates of nitrogen, phosphorus, and potassium into the form of the fertilizer type (NN-PP-KK). The program searches for a known type of fertilizer by dividing each of the rates by a certain number. The recommended rate of nitrogen is always $50 \mathrm{lbs} /$ acre $(56 \mathrm{~kg} / \mathrm{ha})$ so this helps to find a number to divide by to find a known type of fertilizer. The common types of fertilizer used by the WVDOH are 10-20-10, 8-16-8, 12-24-12, 5-10-5, and 15-30-15 (WVDOH 2010). The program begins by dividing each rate by 5 to test for the 10-20-10 fertilizer type. If the adjusted rate of fertilizer is not within $10 \%$ of the $10-20-10$ rate then the program tests the remaining known types by adjusting the $50 \mathrm{lbs} /$ acre $(56 \mathrm{~kg} / \mathrm{ha}$ ) of nitrogen down to $8,12,5$, or 15 . If the 
program cannot find a match to one of the known types of fertilizer, then it creates a new type of fertilizer and suggests a recommended rate that the fertilizer should be applied to the soil. The program calculates a new type of fertilizer that does not have a defined price so manual calculations will need to be performed.

The program also calculates the rate of HGMs that should be added to the area if organic matter is not sufficient ( $<3 \%$ of soil weight as defined by the revised specifications). In order to calculate the rates of HGMs, slope, organic matter and soil composition need to be known. This is because HGMs contain two components, an organic matter component and a soil stabilizer. The organic matter is dependent on the slope or existing organic matter of the soil. The higher application rate for slope or organic matter percentage is chosen as the minimum application rate for the organic matter component. The soil stabilizer application rate is dependent on the slope and dominant type of soil the HGM would be added. The two dominant soil types the program uses are sand and clay, as the revised specifications require.

The program only calculates the minimum application rates of fertilizer, agricultural granular limestone, and HGMs as recommended by the revised specifications in the soil test input section of the program. If soil amendment application rates are provided by a laboratory soil test as outlined in the revised specifications, the results from that test should be used. Another special case is HGMs may not be required on a site that is lacking the organic matter content in the soil. In that case, a BGS should be used and manual calculations will need to be performed according to manufacturer specifications for that brand of BGS.

\subsubsection{4: Running the program}

The program is run by a simple click of a button implemented into the program that is shown in Figure 2. The program also contains a "clear" button for both the input and output sheets to erase data from previous iterations of the program. Clearing the data is an effective way to remove the data from the input or output worksheets for the next iteration of the program. The program also asks the user whether they want to clear existing data from the input sheet when updating the number of planting areas. This is so a user can start a clean version of the program or to keep data for the existing areas if it is found more areas need to be added to the sheet.

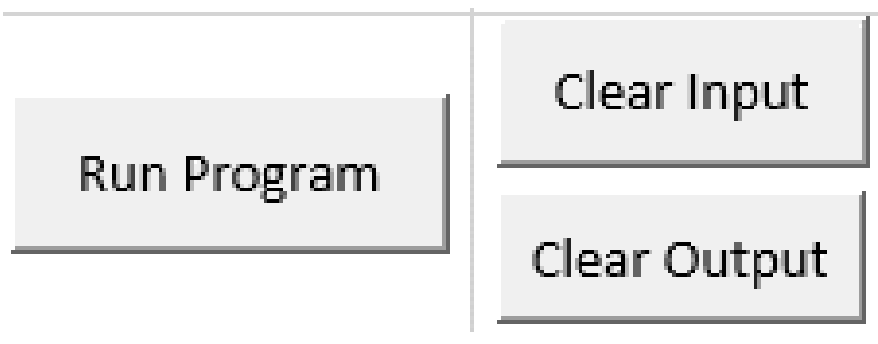

Figure 2: Program buttons 


\subsection{3: Output}

The output sheet of the program displays all the application rates, prices, and special notes associated with each material in each area. Figure 3 shows a blank example of the output for Area 1. The output sheet also shows the total price of each material from each area (Figure 4). The final item shown on the output sheet is the description of all the special notes than can be found on the output sheet (Figure 5).

The output sheets provides a summary of all the materials that have been selected for each area with their inputted or calculated application rates. This allows for the user to efficiently double check calculations, use certain prices for items, or to print the results of the program. In order for consistent printing of reports, a print button was added to the output sheet that prints the results to a PDF file for compatibility across multiple platforms. 


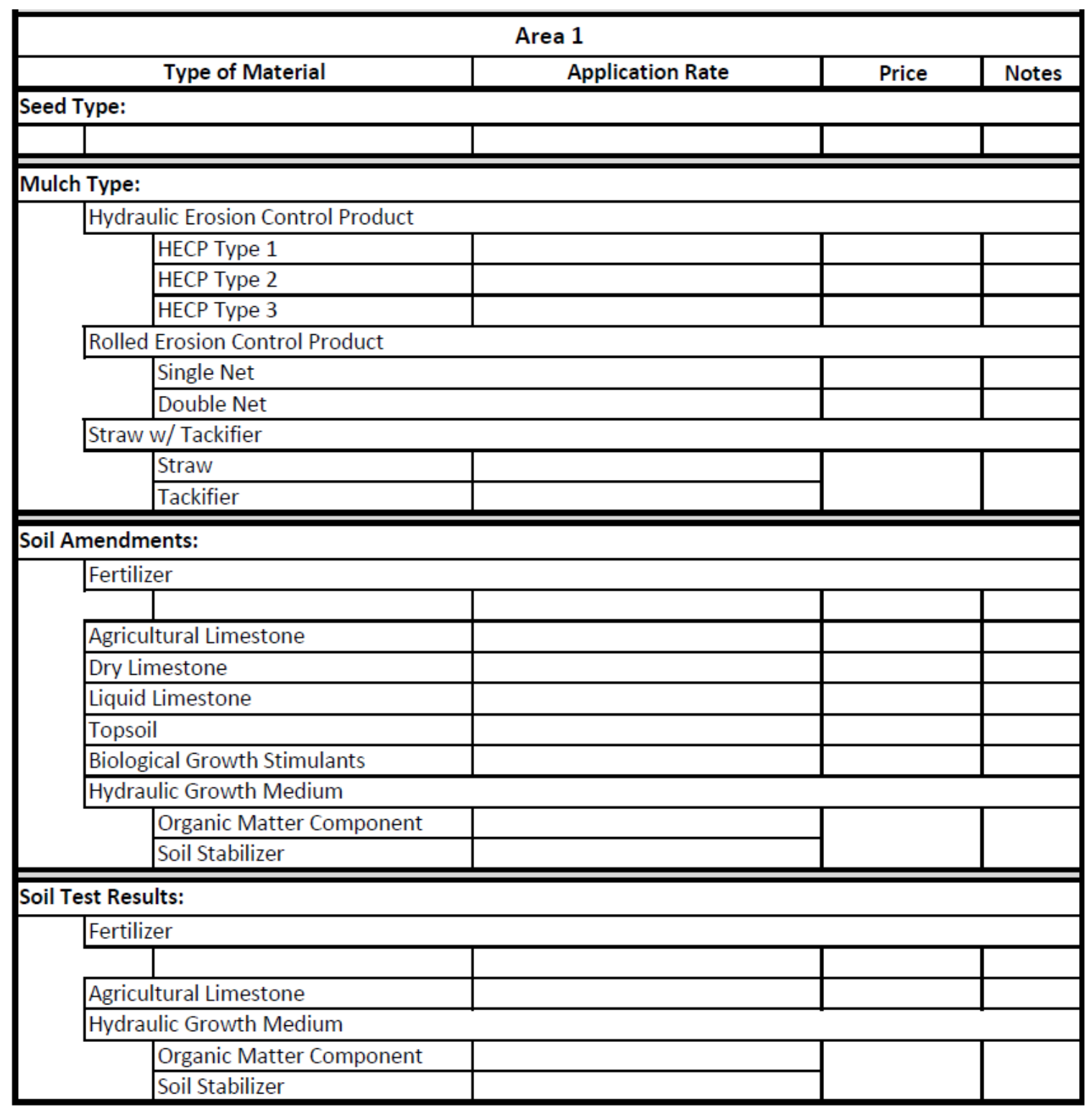

Figure 3: Example output for Area 1 


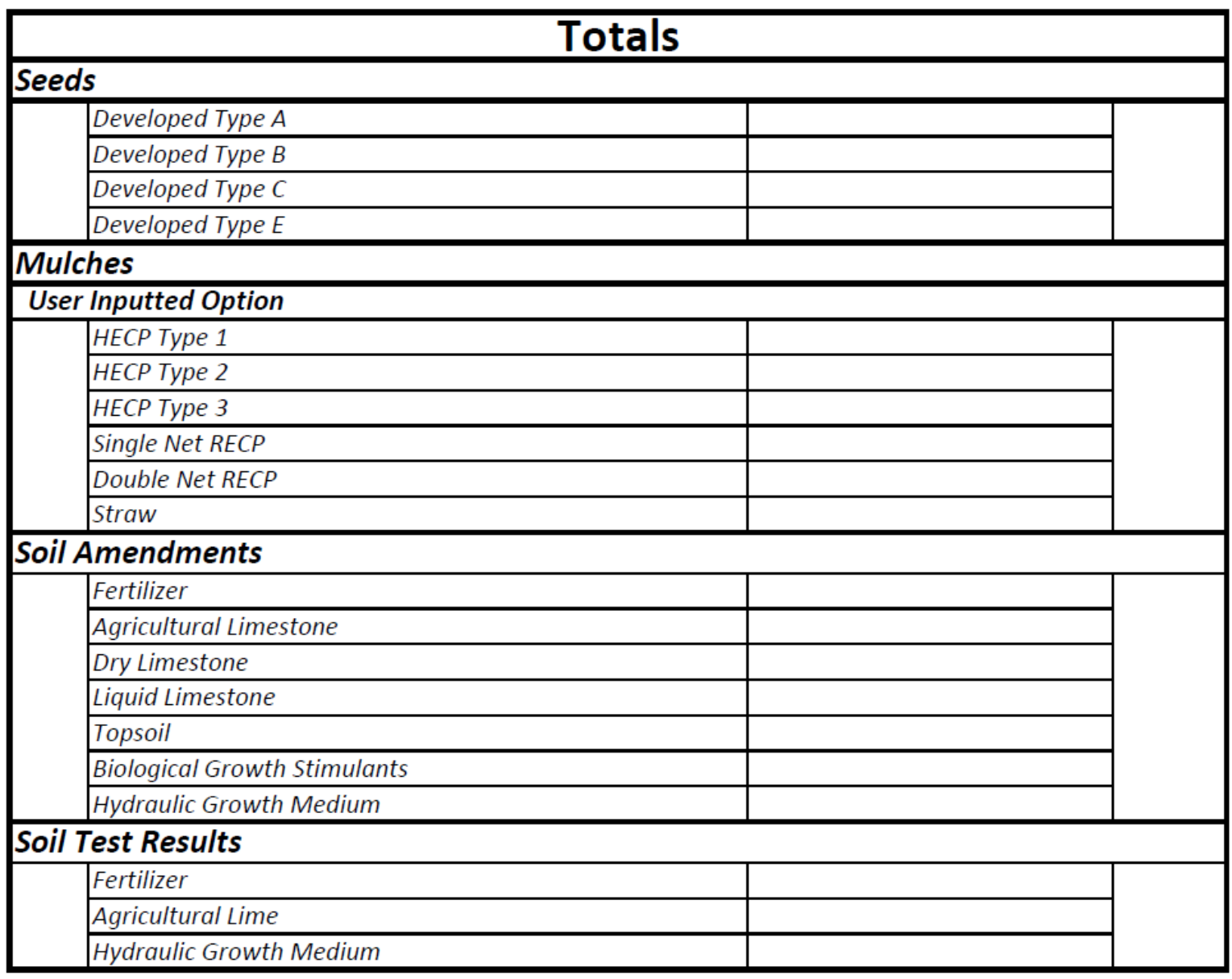

Figure 4: Output totals for each material 


\begin{tabular}{|l|l|}
\hline \multicolumn{2}{|l|}{ Notes } \\
\hline a) & The seed type selected is outside of the selected planting dates. \\
\hline b) & $\begin{array}{l}\text { The inputted mulch application rate is less than the minimum. The minimum rate was used for this } \\
\text { calculation. }\end{array}$ \\
\hline c) & Straw mulch cannot be applied to a slope greater than $2 \mathrm{H}: 1 \mathrm{~V}$. \\
\hline d) & Straw mulch cannot be applied to a slope greater than $4 \mathrm{H}: 1 \mathrm{~V}$ for more than an acre. \\
\hline e) & $\begin{array}{l}\text { Topsoil and hydraulic growth mediums should not be used on the same area. The cheaper option } \\
\text { should be chosen. }\end{array}$ \\
\hline f) & $\begin{array}{l}\text { Biological growth stimulants and hydraulic growth mediums should not be used on the same area. The } \\
\text { cheaper option should be chosen. }\end{array}$ \\
\hline g) & $\begin{array}{l}\text { Hydraulic growth mediums cannot be applied to a slope greater than } 2 \mathrm{H}: 1 \mathrm{~V} \text {. Biological growth } \\
\text { stimulants are recommended for this area. }\end{array}$ \\
\hline h) & $\begin{array}{l}\text { The inputted hydraulic growth medium rate is less than the minimum rate. The minimum rate was } \\
\text { used for this calculation. }\end{array}$ \\
\hline i) & Undefined fertilizer type. No price could be found. \\
\hline j) & The buffer pH is out of the range of the chart. \\
\hline 1) & User inputted mulch type. \\
\hline
\end{tabular}

Figure 5: Special output notes

\subsection{Case Studies}

\subsection{1: 47 Interchange}

\subsubsection{1: Field Site Description}

The 47 Interchange site was located on Route 50 at the West Virginia 47 / Staunton Avenue exit (N 39 $15^{\prime} 20.2^{\prime \prime}$, W 81 $31^{\prime}$ 45.1'). The area was approximately 10 acres (4.0 ha) in size that had two different slopes associated with it. One slope was a highway cut (Figure 6) and the other was a flat slope adjacent to a parking lot (Figure 7). The area had two different types of soils, each located on the different slopes. A red soil with a shale consistency was located on the highway cut and a yellow soil with a shale consistency was located on the flat slope (Hopkinson et al. 2016). These two areas are good examples of how a single area within a highway construction zone can contain different slopes and types of soils which require different methods of seeding and mulching. 


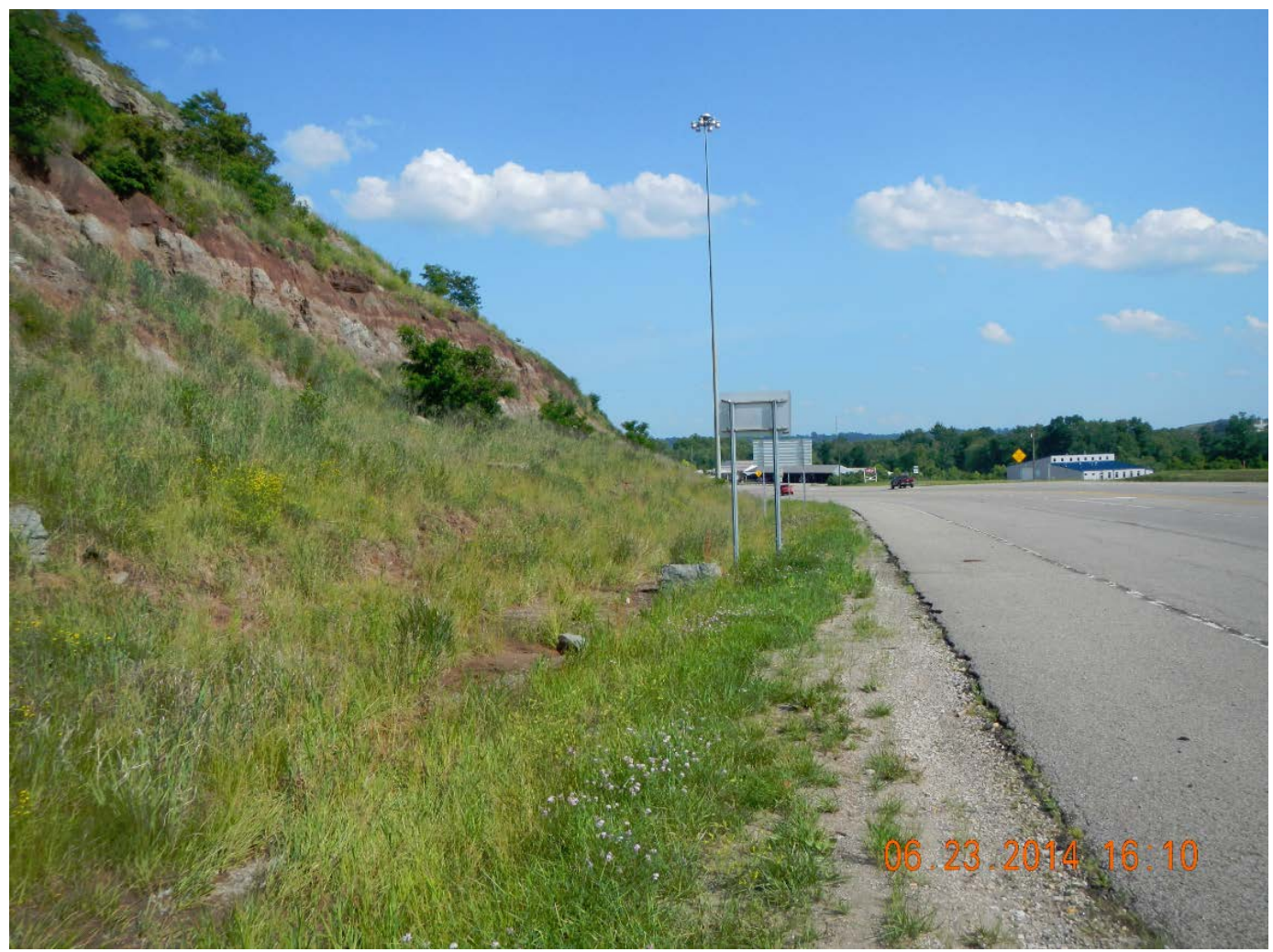

Figure 6: 47INTA site

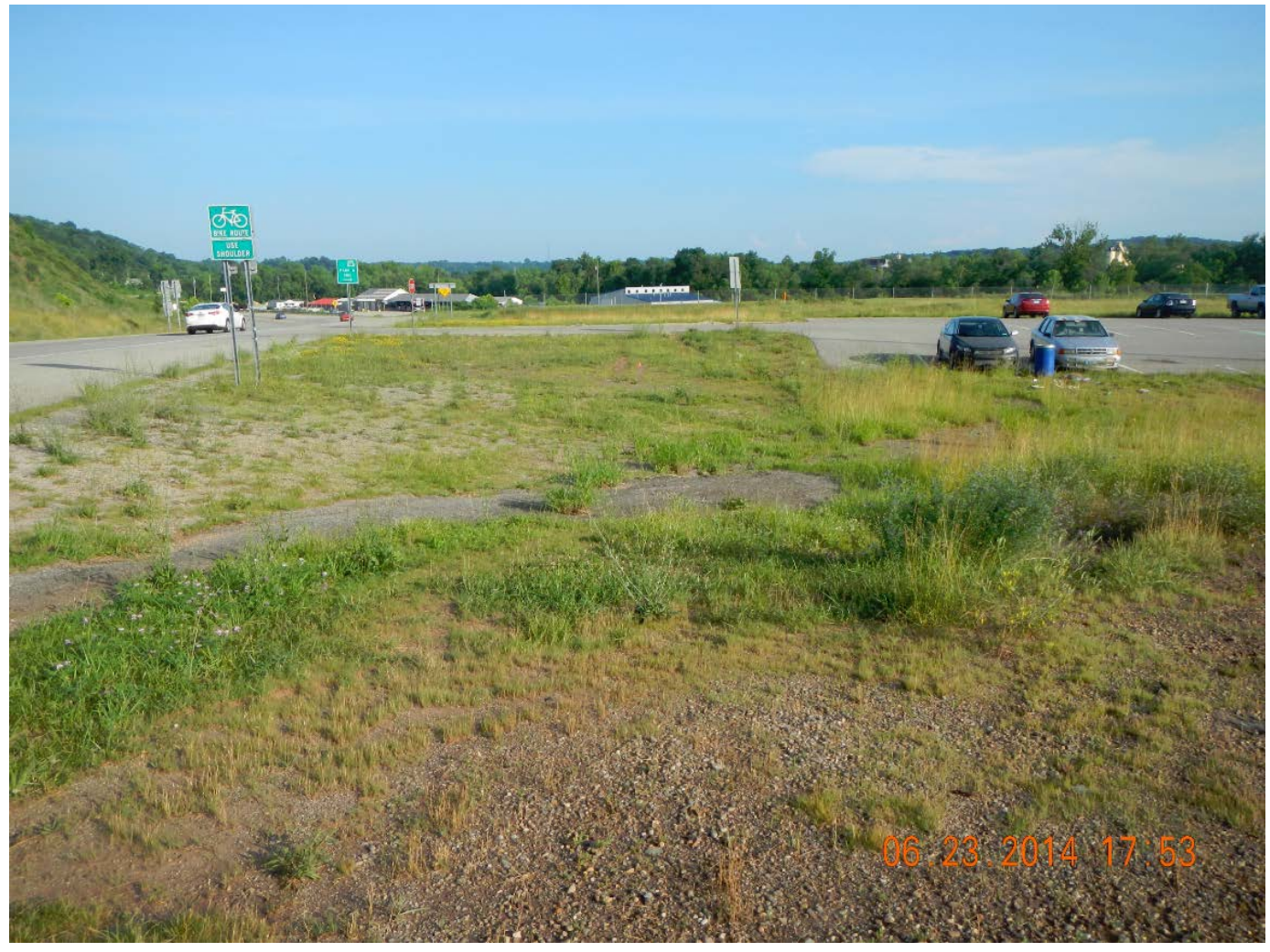

Figure 7: 47INTB site 
In order to perform a cost analysis on this site, information about the site was gathered. The site had a soil test performed by AgSource Laboratories located in Lincoln, NE. The results from the soil test can be found in Table 9. The site name for 47INTA corresponds to the highway cut (Figure 6) and 47INTB corresponds to the flat slope (Figure 7). The soils had similar results from the soil test despite the color differences. No soil amendment recommendations were requested for the sites as these sites already had established vegetation.

Table 9: 47 Interchange soil test results

\begin{tabular}{|c|c|c|c|c|c|c|c|c|c|c|}
\hline $\begin{array}{c}\text { Site } \\
\text { Name }\end{array}$ & $\begin{array}{c}\text { Soil } \\
\text { Type }\end{array}$ & $\begin{array}{c}\% \\
\text { Clay }\end{array}$ & $\begin{array}{c}\% \\
\text { Sand }\end{array}$ & $\%$ Silt & $\% \mathrm{OM}$ & $\mathrm{pH}$ & $\begin{array}{c}\text { Buffer } \\
\mathrm{pH}\end{array}$ & $\mathrm{N} \mathrm{ppm}$ & $\mathrm{P}$ ppm & $\mathrm{K}$ ppm \\
\hline 47INTA & Loam & 16.4 & 37.6 & 46 & 1 & 9.6 & 7.5 & 1 & 5 & 153 \\
\hline 47INTB & Loam & 18.4 & 47.6 & 34 & 1 & 9.3 & 7.5 & 2 & 2 & 160 \\
\hline
\end{tabular}

Slope was measured at the site with a Suunto PM-5 Clinometer (Hopksinson et al. 2016). The mean slopes at each area in the site can be found in Table 10. The slope for 47INTA is rounded to $5 \mathrm{H}: 1 \mathrm{~V}$ for the program input. The slope for 47INTB is changed to the "Flat" slope category for the program input.

Table 10: Slope results for 47 Interchange

\begin{tabular}{|c|c|c|}
\hline Site Name & Slope $(\%)$ & Slope $(\mathrm{H}: \mathrm{V})$ \\
\hline 47INTA & 19.0 & $5.2 \mathrm{H}: 1 \mathrm{~V}$ \\
\hline 47INTB & 5.8 & $17.2 \mathrm{H}: 1 \mathrm{~V}$ \\
\hline
\end{tabular}

\subsubsection{2: Program Input}

The data collected was entered into the input sheet of the program to determine a cost analysis of seeding and mulching the two areas located on the 47 Interchange site (Figure 8). Area 1 corresponds to 47INTA and area 2 corresponds to 47INTB. The total of 10 acres (4.0 ha) for the site was split evenly among the two areas. The type of seed for 47INTA was chosen to be developed type $B$ because the area is classified as a highway cut. The type of seed for 47INTB was chosen to be developed type $A$ because the area is classified as a mowable area adjacent to a parking lot. The type of mulch for 47INTA was chosen to be HECP and the type of mulch for 47INTB was chosen to be straw mulch. 


\begin{tabular}{|c|c|c|c|c|c|}
\hline & \multicolumn{2}{|l|}{ Site Parameters } & Custom Price & \multicolumn{2}{|c|}{ Soil Test Results } \\
\hline \multirow{14}{*}{ Area 1} & Area (acres) & 5 & & $\mathrm{pH}$ & 9.6 \\
\hline & Slope (H:V) & $5: 1$ & & Buffer $\mathrm{pH}$ & 7.5 \\
\hline & Type of Seed & Developed Type B & & $\%$ Organic Matter & 1 \\
\hline & Type of Mulch & HECP & & Nitrogen (ppm) & 1 \\
\hline & Mulch Application Rate (HECP-Ibs/acre) (Straw-tons/acre) & & & Phosphorus (ppm) & 5 \\
\hline & Fertilizer Required (tons/acre) & & & Potassium (ppm) & 153 \\
\hline & Fertilizer Type (N-P-K) & & & $\%$ Clay & 16.4 \\
\hline & Agricultural Limestone Required (tons/acre) & & & $\%$ Silt & 37.6 \\
\hline & \begin{tabular}{|l|} 
Dry Limestone Required (lbs/acre) \\
\end{tabular} & & & \%Sand & 46 \\
\hline & Liquid Limestone Required (gallons/acre) & & & Soil Type & \\
\hline & Topsoil Required (cubic yards) & & & & \\
\hline & Biological Growth Stimulant Required (Ibs/acre) & & & & \\
\hline & Hydraulic Growth Medium Organic Component (Ibs/acre) & & & & \\
\hline & Hydraulic Growth Medium Soil Stabillizer (Ibs/acre) & & & & \\
\hline \multirow{14}{*}{ Area 2} & Area (acres) & 5 & & $\mathrm{pH}$ & 9.3 \\
\hline & Slope (H:V) & Flat & & Buffer $\mathrm{pH}$ & 7.5 \\
\hline & Type of Seed & Developed Type A & & $\%$ Organic Matter & 1 \\
\hline & Type of Mulch & Straw & & Nitrogen (ppm) & 2 \\
\hline & Mulch Application Rate (HECP-Ibs/acre) (Straw-tons/acre) & & & Phosphorus (ppm) & 2 \\
\hline & Fertilizer Required (tons/acre) & & & Potassium (ppm) & 160 \\
\hline & Fertilizer Type (N-P-K) & & & $\%$ Clay & 18.4 \\
\hline & Agricultural Limestone Required (tons/acre) & & & $\%$ Silt & 47.6 \\
\hline & Dry Limestone Required (Ibs/acre) & & & $\%$ Sand & 34 \\
\hline & Liquid Limestone Required (gallons/acre) & & & Soil Type & \\
\hline & Topsoil Required (cubic yards) & & & & \\
\hline & Biological Growth Stimulant Required (Ibs/acre) & & & & \\
\hline & Hydraulic Growth Medium Organic Component (Ibs/acre) & & & & \\
\hline & Hydraulic Growth Medium Soil Stabilizer (Ibs/acre) & & & & \\
\hline
\end{tabular}

Figure 8: 47 Interchange input

\subsubsection{3: Program Output}

After the program was run, the output sheet was printed. Area 1, or 47INTA, can be found in Figure 9 and Area 2, or 47INTB, can be found in Figure 10. These outputs show the cost of using the specified materials in the program input as shown in the previous section.

The seed type chosen for 47INTA was developed type B. This seed mixture has planting dates between March $1^{\text {st }}$ and June $20^{\text {th }}$ and again from October $1^{\text {st }}$ to October $31^{\text {st }}$. The planting date that was chosen was September $1^{\text {st }}, 2017$ as shown in Figure 9. The planting date was out of the range of the planting dates for developed type $B$ seed mixture so the program printed a note for the user. The seed type chosen for 47INTB was developed type A. This seed mixture has planting dates of February $15^{\text {th }}$ to June $20^{\text {th }}$ and August $1^{\text {st }}$ to October $31^{\text {st }}$. The planting date was in these date ranges so no special note "a" was included for 47INTB.

The program calculates the price of the three mulching practices: HECP, RECP, and Straw. This allows the user to identify which option could be the most cost effective. The program will always print a " 1 " in the notes column for the mulch that was chosen on the input sheet for the area. This mulch is also the mulch that is used for the price totals calculation on the totals output. For 47INTA the chosen mulch, HECP, was the cheapest option while 47INTB's chosen mulch, straw mulch, is slightly cheaper than the HECP option.

The program did not have any soil amendment recommendations in the input boxes so this section does not contain any output information. The soil amendments that are recommended to be added to this site were calculated using the soil test results. The program 
calculated that 47INTA should be remediated with a 10-18-6 fertilizer at an application rate of 0.25 tons/acre (560 kg/ha), and 47INTB should be remediated with a 10-20-0 fertilizer at a rate of 0.25 tons/acre $(560 \mathrm{~kg} / \mathrm{ha})$. The program did not calculate prices for the fertilizer because those types of fertilizer are not known by the program. The user is recommended to find the types of fertilizers and perform a new cost analysis for the fertilizer by hand. If the types of fertilizers cannot be found, a similar type of fertilizer should be chosen and the application rate recalculated along with the associated price.

The program did not calculate a rate of agricultural limestone because the $\mathrm{pH}$ of 47INTA was 9.6 and 47INTB was 9.3. This is above the recommended $\mathrm{pH}$ of 6.5 for both of the developed type $A$ and $B$ seed mixtures. If the areas had a pH below 6.5 then the program would have calculated a rate of agricultural limestone according to the $\mathrm{pH}$ and the buffer $\mathrm{pH}$.

The program calculated that a HGM should be added to both of the areas, because the organic matter of the areas was low (1\%). This is below the recommended organic matter of 3\% in the revised specifications. The program calculated the rates of the organic matter component and soil stabilizer according to the revised specifications.

The program totals can be found in Figure 11. The totals sheet sums up all of the price estimates for each material in each area. The only exception to this is that the mulch section only totals up the user inputted option from each area. This allows for the user to have a total of each material or chose a few totals for different materials. 


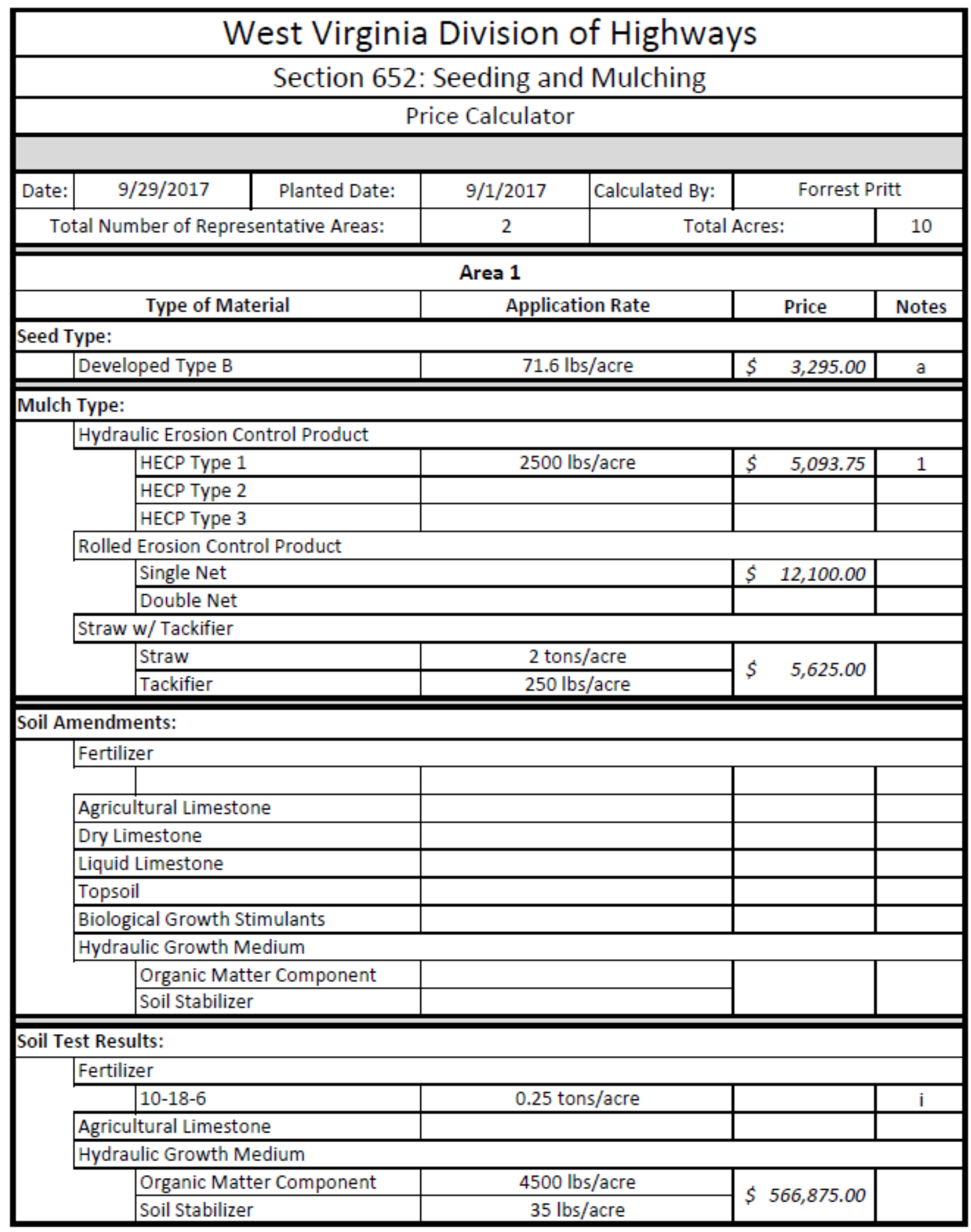

Figure 9: 47INTA cost analysis output 


\begin{tabular}{|c|c|c|c|}
\hline \multicolumn{4}{|c|}{ Area 2} \\
\hline Type of Material & Application Rate & Price & Notes \\
\hline \multicolumn{4}{|l|}{ Seed Type: } \\
\hline Developed Type A & $163.56 \mathrm{lbs} / \mathrm{acre}$ & $2,392.64$ & \\
\hline \multicolumn{4}{|l|}{ Mulch Type: } \\
\hline \multicolumn{4}{|l|}{ Hydraulic Erosion Control Product } \\
\hline \begin{tabular}{|l|l|} 
HECP Type 1 \\
\cline { 2 - 2 }
\end{tabular} & $2500 \mathrm{lbs} / \mathrm{acre}$ & $5,093.75$ & \\
\hline HЕСР Туре 2 & & & \\
\hline $\begin{array}{ll}\text { HECP Type } 3 \\
\end{array}$ & & & \\
\hline \multicolumn{4}{|l|}{ Rolled Erosion Control Product } \\
\hline \begin{tabular}{l|l} 
Single Net \\
\cline { 2 - 2 }
\end{tabular} & & $\$ 12,100.00$ & \\
\hline \multicolumn{4}{|l|}{ Double Net } \\
\hline \multicolumn{4}{|l|}{ Straw w/ Tackifier } \\
\hline \begin{tabular}{l|l|} 
Straw \\
\end{tabular} & 2 tons/acre & \multirow{2}{*}{$\$ \quad 5,625.00$} & \multirow{2}{*}{1} \\
\hline Tackifier & $250 \mathrm{lbs} / \mathrm{acre}$ & & \\
\hline \multicolumn{4}{|l|}{ Soil Amendments: } \\
\hline \multicolumn{4}{|l|}{ Fertilizer } \\
\hline & & & \\
\hline \multicolumn{4}{|l|}{ Agricultural Limestone } \\
\hline \multicolumn{4}{|l|}{ Dry Limestone } \\
\hline \multicolumn{4}{|l|}{ Liquid Limestone } \\
\hline \multicolumn{4}{|l|}{ Topsoil } \\
\hline \multicolumn{4}{|l|}{ Biological Growth Stimulants } \\
\hline \multicolumn{4}{|l|}{ Hydraulic Growth Medium } \\
\hline \multicolumn{4}{|l|}{\begin{tabular}{|l|l|} 
& Organic Matter Component \\
\cline { 2 - 3 }
\end{tabular}} \\
\hline \multicolumn{4}{|l|}{ Soil Stabilizer } \\
\hline \multicolumn{4}{|l|}{ Soil Test Results: } \\
\hline \multicolumn{4}{|l|}{\begin{tabular}{|l|l|} 
Fertilizer \\
\end{tabular}} \\
\hline \begin{tabular}{|l|l|} 
& $10-20-0$ \\
\end{tabular} & 0.25 tons/acre & & $\mathrm{i}$ \\
\hline \multicolumn{4}{|l|}{ Agricultural Limestone } \\
\hline \multicolumn{4}{|l|}{ Hydraulic Growth Medium } \\
\hline \begin{tabular}{l|l} 
Organic Matter Component \\
\end{tabular} & $4500 \mathrm{lbs} /$ acre & $\leqslant 56687500$ & \\
\hline Soil Stabilizer & $35 \mathrm{lbs} /$ acre & $3500,815.00$ & \\
\hline
\end{tabular}

Figure 10: 47INTB cost analysis output 


\begin{tabular}{|c|c|c|}
\hline \multicolumn{3}{|c|}{ Totals } \\
\hline \multicolumn{3}{|l|}{ Seeds } \\
\hline \begin{tabular}{l|l} 
Developed Type A \\
\end{tabular} & $\$$ & $2,393.00$ \\
\hline Developed Type B & $\$$ & $3,295.00$ \\
\hline Developed Type C & $\$$ & - \\
\hline Developed Type E & $\$$ & - \\
\hline \multicolumn{3}{|l|}{ Mulches } \\
\hline \multicolumn{3}{|l|}{ User Inputted Option } \\
\hline \begin{tabular}{l|l} 
HECP Type 1 \\
\end{tabular} & $\$$ & $5,094.00$ \\
\hline HECP Type 2 & $\$$ & - \\
\hline HECP Type 3 & $\$$ & - \\
\hline Single Net RECP & $\$$ & - \\
\hline Double Net RECP & $\$$ & - \\
\hline Straw & S & $5,625.00$ \\
\hline \multicolumn{3}{|l|}{ Soil Amendments } \\
\hline \begin{tabular}{l|l} 
Fertilizer \\
\end{tabular} & $\$$ & - \\
\hline Agricultural Limestone & $\$$ & - \\
\hline Dry Limestone & $\$$ & - \\
\hline Liquid Limestone & $\$$ & - \\
\hline Topsoil & $\$$ & - \\
\hline Biological Growth Stimulants & $\$$ & - \\
\hline Hydraulic Growth Medium & $\$$ & - \\
\hline \multicolumn{3}{|l|}{ Soil Test Results } \\
\hline \begin{tabular}{l|l} 
Fertilizer \\
\end{tabular} & $\$$ & - \\
\hline Agricultural Lime & $\$$ & - \\
\hline Hydraulic Growth Medium & $\$$ & $1,133,750.00$ \\
\hline
\end{tabular}

Figure 11: 47 Interchange cost analysis totals

\subsection{2: Route 279 Roadside}

\subsubsection{1: Field Site Description}

The Route 279 site was located near the Benedum Drive exit (N 39 18' 43.7', W 80 13' 7.4"). Site 1 was located on the east side of the exit (Figure 12) and site 2 was located on the west side of the exit (Figure 13). Both areas contained steep highway cut slopes. Site 1 had two different soils located on the cut. Site 2 only contained 1 type of soil (Hopkinson et al. 2016). These two areas contain three different types of soils within a small construction zone, which would require three soil tests as required by the revised specifications. 


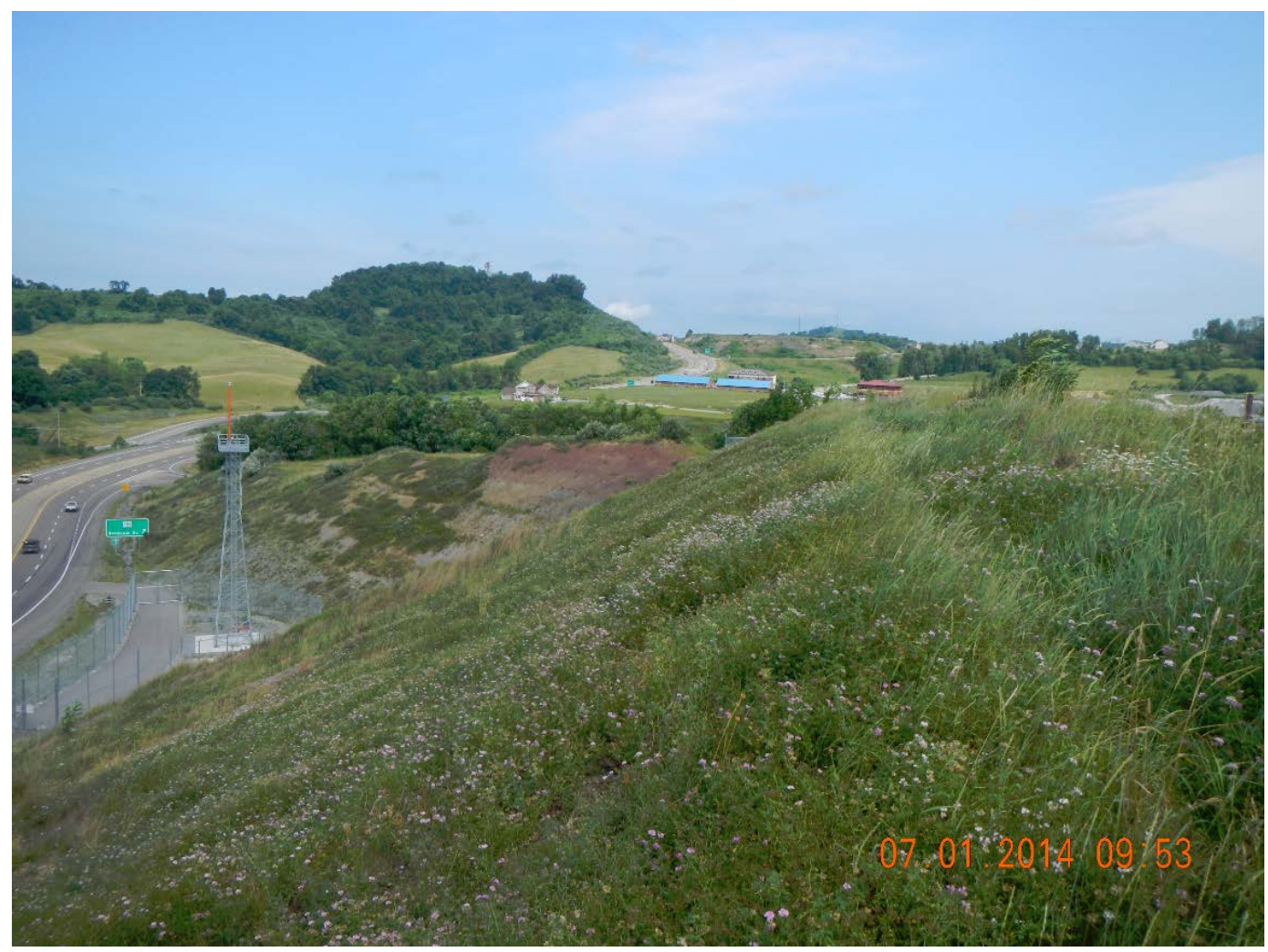

Figure 12: 279S1 site

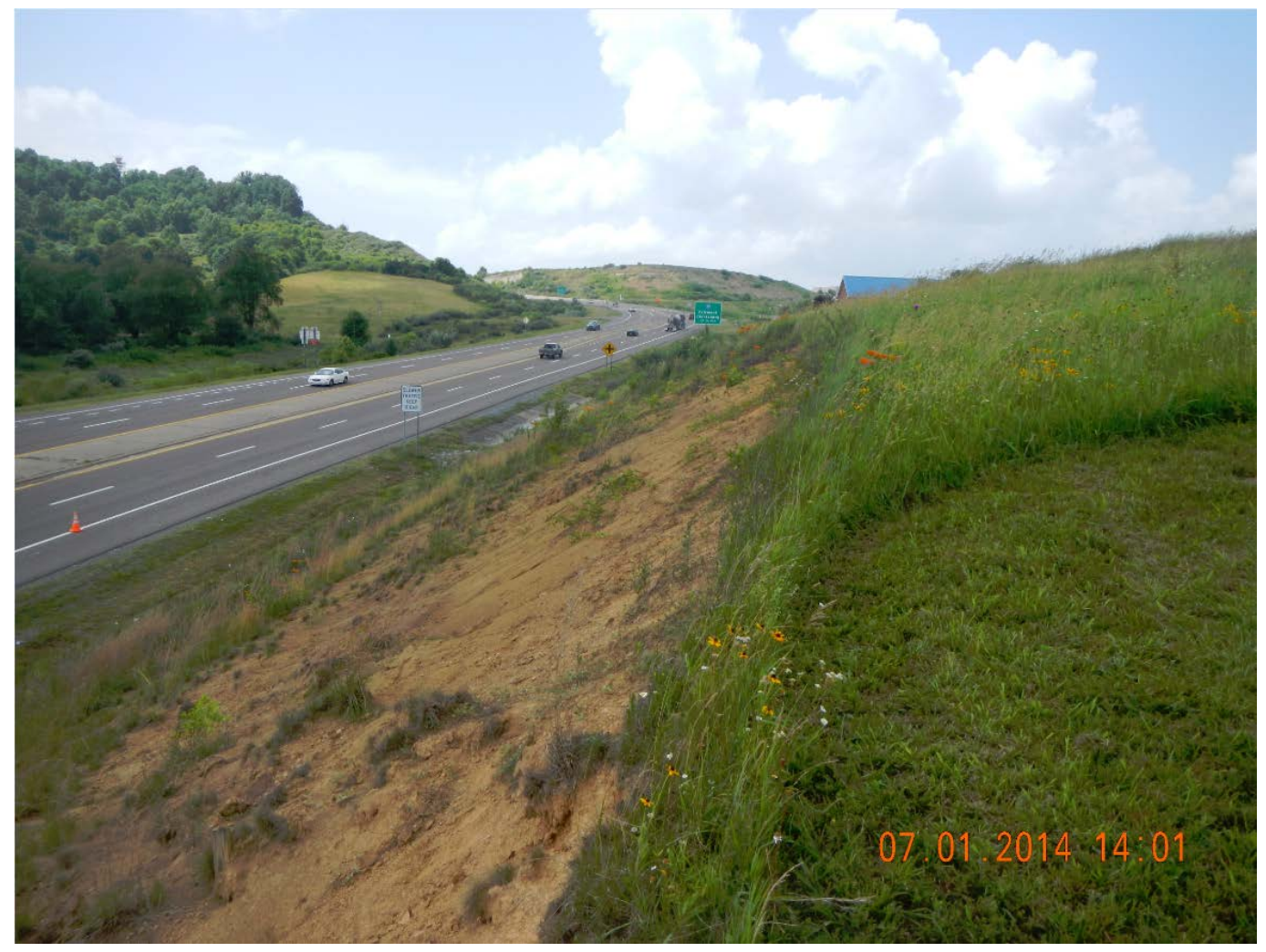

Figure 13: 279S2 site 
The site had a soil test performed by AgSource Laboratories located in Lincoln, NE. The results from the soil test can be found in Table 11. The site name for 2791A corresponds to soil 1 from site 1 and 2791B corresponds to soil 2 from site 1 on the east side of the exit (Figure 12). The site name 279S2 corresponds to the soil found on site 2 on the west side of the exit (Figure 13). The two soils on site 1 showed similar properties and were different from site 2 soil. No soil amendment recommendations were requested for the sites as these sites already had established vegetation.

Table 11: Route 279 soil test results

\begin{tabular}{|c|c|c|c|c|c|c|c|c|c|c|}
\hline $\begin{array}{c}\text { Site } \\
\text { Name }\end{array}$ & $\begin{array}{c}\text { Soil } \\
\text { Type }\end{array}$ & \% Clay & \% Sand & \% Silt & $\% O M$ & $\mathrm{pH}$ & $\begin{array}{c}\text { Buffer } \\
\mathrm{pH}\end{array}$ & $\mathrm{N} \mathrm{ppm}$ & $\mathrm{P}$ ppm & $\mathrm{K}$ ppm \\
\hline $2791 \mathrm{~A}$ & $\begin{array}{c}\text { Sandy } \\
\text { Loam }\end{array}$ & 12.4 & 71.6 & 16 & 1.6 & 8 & 7.5 & 3 & 3 & 179 \\
\hline $2791 \mathrm{~B}$ & $\begin{array}{c}\text { Sandy } \\
\text { Loam }\end{array}$ & 10.4 & 71.6 & 18 & 1.6 & 8 & 7.5 & 6 & 2 & 222 \\
\hline $279 S 2$ & Loam & 22.4 & 49.6 & 28 & 1.8 & 5.7 & 6.7 & 1 & 4 & 125 \\
\hline
\end{tabular}

Slope was measured at the site with a Suunto PM-5 Clinometer (Hopkinson et al. 2016). The mean slopes at each area in the sites can be found in Table 12. The slope for all three areas were rounded to $2 \mathrm{H}: 1 \mathrm{~V}$ for the program input.

Table 12: Slope results for Route 279

\begin{tabular}{|c|c|c|}
\hline Site Name & Slope $(\%)$ & Slope $(\mathrm{H}: \mathrm{V})$ \\
\hline $2791 \mathrm{~A}$ & 45.3 & $2.2 \mathrm{H}: 1 \mathrm{~V}$ \\
\hline $2791 \mathrm{~B}$ & 47.2 & $2.1 \mathrm{H}: 1 \mathrm{~V}$ \\
\hline $279 \mathrm{~S} 2$ & 49.1 & $2.0 \mathrm{H}: 1 \mathrm{~V}$ \\
\hline
\end{tabular}

\subsubsection{2: Program Input}

The data were entered into the input sheet of the program to determine a cost analysis of seeding and mulching the three areas located on the Route 279 sites. The information used in the program can be found in Figure 14. Area 1 corresponds to 2791A, area 2 corresponds to 2791B, and area 2 corresponds to 279S2. Area 2791A was given 3 acres (1.2 ha), 2791B was given 2 acres ( $0.8 \mathrm{ha}$ ), and 279S2 was given 1 acre (0.4 ha). These numbers are arbitrary and are used to show different results from the program. The type of seed for site 1 was chosen to be developed type $\mathrm{B}$ because the area is classified as a highway cut. The type of seed for site 2 was chosen to be developed type $C$ because the area is also classified as a highway cut. The type of mulch for 2791A was chosen to be HECP, the type for 2791B was chosen to be RECP, and the type for 27952 was chosen to be straw mulch. 


\begin{tabular}{|c|c|c|c|c|c|}
\hline & \multicolumn{2}{|l|}{ Site Parameters } & Custom Price & \multicolumn{2}{|c|}{ Soil Test Results } \\
\hline \multirow{14}{*}{ Area 1} & Area (acres) & 3 & & $\mathrm{pH}$ & 8 \\
\hline & Slope $(\mathrm{H}: \mathrm{V})$ & $2: 1$ & & Buffer $\mathrm{pH}$ & 7.5 \\
\hline & Type of Seed & Developed Type B & & $\%$ Organic Matter & 1.6 \\
\hline & Type of Mulch & HECP & & Nitrogen $(\mathrm{ppm})$ & 3 \\
\hline & Mulch Application Rate (HECP-Ibs/acre) (Straw-tons/acre) & & & Phosphorus (ppm) & 3 \\
\hline & Fertilizer Required (tons/acre) & & & Potassium (ppm) & 179 \\
\hline & Fertilizer Type (N-P-K) & & & $\%$ Clay & 12.4 \\
\hline & Agricultural Limestone Required (tons/acre) & & & \%Silt & 71.6 \\
\hline & Dry Limestone Required (Ibs/acre) & & & \%Sand & 16 \\
\hline & Liquid Limestone Required (gallons/acre) & & & Soil Type & \\
\hline & Topsoil Required (cubic yards) & & & & \\
\hline & Biological Growth Stimulant Required (Ibs/acre) & & & & \\
\hline & Hydraulic Growth Medium Organic Component (Ibs/acre) & & & & \\
\hline & Hydraulic Growth Medium Soil Stabillizer (Ibs/acre) & & & & \\
\hline \multirow{14}{*}{ Area 2} & Area (acres) & 2 & & $\mathrm{pH}$ & 8 \\
\hline & Slope $(\mathrm{H}: \mathrm{V})$ & $2: 1$ & & Buffer $\mathrm{pH}$ & 7.5 \\
\hline & Type of Seed & Developed Type B & & $\%$ Organic Matter & 1.6 \\
\hline & Type of Mulch & RECP & & Nitrogen (ppm) & 6 \\
\hline & Mulch Application Rate (HECP-Ibs/acre) (Straw-tons/acre) & & & Phosphorus (ppm) & 2 \\
\hline & Fertilizer Required (tons/acre) & & & Potassium (ppm) & 222 \\
\hline & Fertilizer Type (N-P-K) & & & $\% \mathrm{Clay}$ & 10.4 \\
\hline & Agricultural Limestone Required (tons/acre) & & & $\%$ Silt & 71.6 \\
\hline & Dry Limestone Required (Ibs/acre) & & & $\%$ Sand & 18 \\
\hline & Liquid Limestone Required (gallons/acre) & & & Soil Type & \\
\hline & Topsoil Required (cubic yards) & & & & \\
\hline & Biological Growth Stimulant Required (Ibs/acre) & & & & \\
\hline & Hydraulic Growth Medium Organic Component (Ibs/acre) & & & & \\
\hline & Hydraulic Growth Medium Soil Stabilizer (Ibs/acre) & & & & \\
\hline \multirow{14}{*}{ Area 3} & Area (acres) & 1 & & $\mathrm{pH}$ & 5.7 \\
\hline & Slope $(\mathrm{H}: \mathrm{V})$ & $2: 1$ & & Buffer $\mathrm{pH}$ & 6.7 \\
\hline & Type of Seed & Developed Type C & & $\%$ Organic Matter & 1.8 \\
\hline & Type of Mulch & Straw & & Nitrogen (ppm) & 1 \\
\hline & Mulch Application Rate (HECP-Ibs/acre) (Straw-tons/acre) & & & Phosphorus (ppm) & 4 \\
\hline & Fertilizer Required (tons/acre) & & & Potassium (ppm) & 125 \\
\hline & Fertilizer Type (N-P-K) & & & \%Clay & 22.4 \\
\hline & Agricultural Limestone Required (tons/acre) & & & $\%$ Silt & 49.6 \\
\hline & Dry Limestone Required (Ibs/acre) & & & $\%$ Sand & 28 \\
\hline & Liquid Limestone Required (gallons/acre) & & & Soil Type & \\
\hline & Topsoil Required (cubic yards) & & & & \\
\hline & Biological Growth Stimulant Required (Ibs/acre) & & & & \\
\hline & Hydraulic Growth Medium Organic Component (Ibs/acre) & & & & \\
\hline & Hydraulic Growth Medium Soil Stabilizer (Ibs/acre) & & & & \\
\hline
\end{tabular}

Figure 14: Route 279 input

\subsubsection{3: Program Output}

After the program was run, the output sheet was printed. Area 1, or 2791A, can be found in Figure 15, Area 2, or 2791B, can be found in Figure 16, and Area 3, or 279S2, can be found in Figure 17. These outputs show the cost of using the specified materials in the program input as shown in the previous section.

The seed type chosen for $2791 \mathrm{~A}$ and $2791 \mathrm{~B}$ was developed type $\mathrm{B}$. This seed mixture has planting dates between March $1^{\text {st }}$ and June $20^{\text {th }}$ and again from October $1^{\text {st }}$ to October $31^{\text {st }}$. The planting date that was chosen was September $1^{\text {st }}, 2017$ as shown in Figure 15. The planting date was out of the range of the planting dates for developed type B seed mixture so the program printed a note for the user. The seed type chosen for 279S2 was developed type A. 
This seed mixture has planting dates of February $15^{\text {th }}$ to June $20^{\text {th }}$ and August $1^{\text {st }}$ to October $31^{\text {st }}$. The planting date was in these date ranges so no special note "a" was included for 27952 .

The mulch types calculated in both of the areas in site 1 were HECP and RECP. Straw mulch calculation was not included because straw mulch cannot be applied to an area with a slope steeper than $4 \mathrm{H}: 1 \mathrm{~V}$ for more than 1 acre (0.4 ha) at a time. For area 2791A, the cheaper option for mulch was the RECP although the HECP was the inputted mulch type. For area 2791B, RECP was the inputted mulch type and it was the cheaper option for the area. For area 279S2, straw mulch was the inputted mulch type and was also the cheapest. Although the slope was $2 \mathrm{H}: 1 \mathrm{~V}$ for $279 \mathrm{~S} 2$, the area was only 1 acre $(0.4 \mathrm{ha})$ in size which allowed for the straw mulch calculation.

The program did not have any soil amendment recommendations in the input boxes so this section does not contain any data. The soil amendments that are recommended to be added to this site were calculated using the soil test results. The program calculated that $2791 \mathrm{~A}$ should be remediated with a 10-20-0 fertilizer at an application rate of 0.25 tons/acre (560 $\mathrm{kg} / \mathrm{ha}$ ), 2791B should also be remediated with a 10-20-0 fertilizer at a rate of 0.25 tons/acre (560 kg/ha), and $279 S 2$ should be remediated with a 10-18-6 fertilizer at a rate of 0.25 tons/acre $(560 \mathrm{~kg} / \mathrm{ha})$. The program did not calculate prices for the fertilizer because those types of fertilizer are not known by the program.

The program did not calculate a rate of agricultural limestone for both of the areas in site 1 because their $\mathrm{pH}$ was greater than 6.5. Agricultural limestone was also not calculated for area $279 \mathrm{~S} 2$ even though the $\mathrm{pH}$ of the site was 5.7, which is lower than the recommended $\mathrm{pH}$ of 6.6. The rate of agricultural limestone was not calculated because the buffer $\mathrm{pH}$ was out of the range of the chart the program uses to calculate rates of limestone application, and the $\mathrm{pH}$ of 5.7 is still within the recommended range for developed type $C$ of $6.6 \pm 1.4$.

The program calculated that a HGM should be added to all three of the areas. This is because the organic matter of the areas was 1.6\%, 1.6\%, and 1.8\% for areas 2791A, 2791B, and 279S2, respectively. This is below the recommended organic matter of $3 \%$. The program calculated the rates of the organic matter component and soil stabilizer according to the revised specifications.

The program totals can be found in Figure 18. The totals sheet sums up all of the price estimates for each material in each area. The only exception to this is the mulch section only totals up the user inputted option from each area. This allows for the user to have a total of each material or chose a few totals for different materials. 


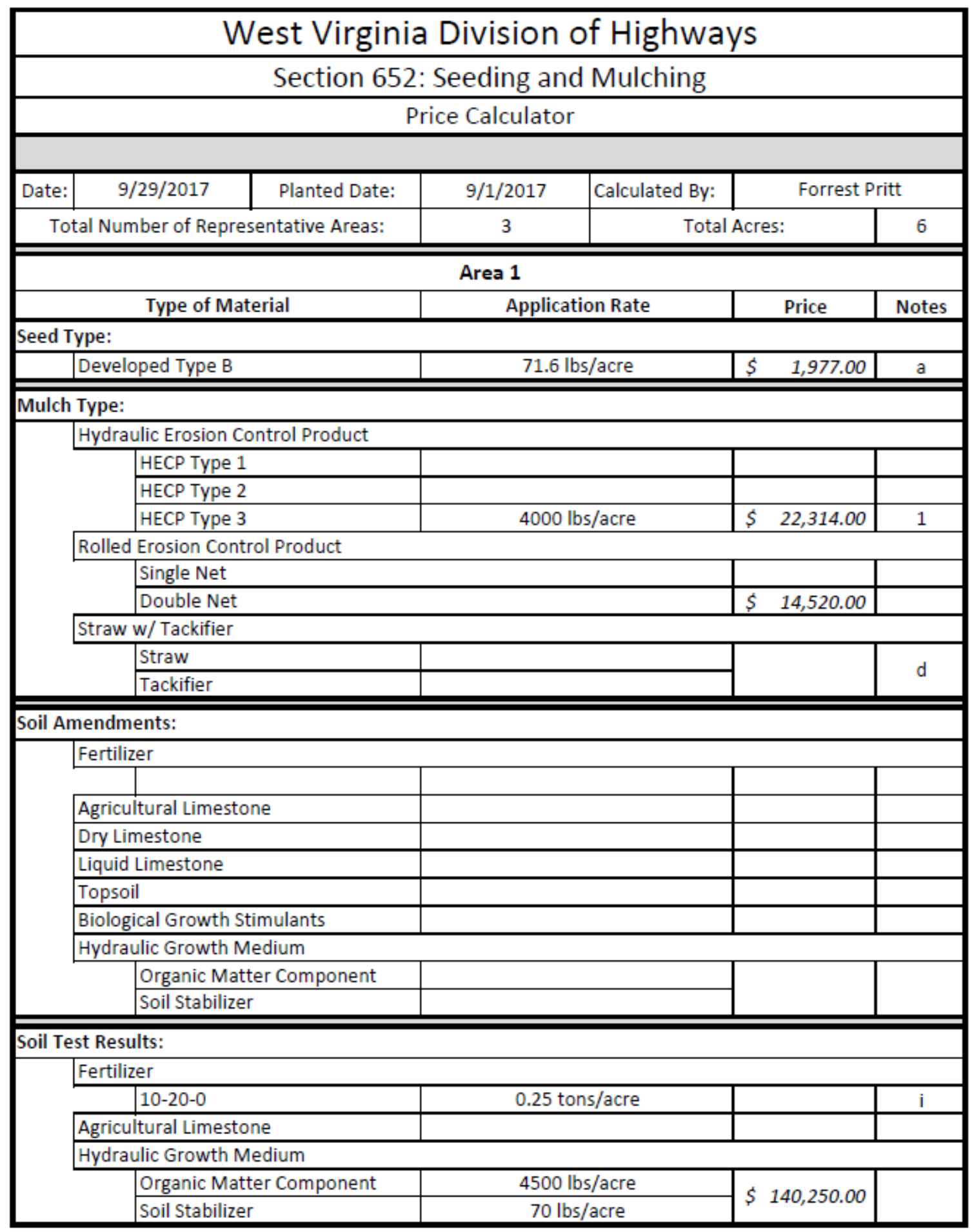

Figure 15: 2791A cost analysis output 


\begin{tabular}{|c|c|c|c|}
\hline \multicolumn{4}{|c|}{ Area 2} \\
\hline Type of Material & Application Rate & Price & Notes \\
\hline \multicolumn{4}{|l|}{ Seed Type: } \\
\hline \begin{tabular}{l|l} 
& Developed Type B \\
\end{tabular} & $71.6 \mathrm{lbs} / \mathrm{acre}$ & $1,318.00$ & a \\
\hline \multicolumn{4}{|l|}{ Mulch Type: } \\
\hline \multicolumn{4}{|l|}{ Hydraulic Erosion Control Product } \\
\hline \begin{tabular}{|l|l|} 
& HECP Type 1 \\
\end{tabular} & & & \\
\hline HECP Type 2 & & & \\
\hline HECP Type 3 & $4000 \mathrm{lbs} / \mathrm{acre}$ & $\$ 14,876.00$ & \\
\hline \multicolumn{4}{|l|}{ Rolled Erosion Control Product } \\
\hline \multicolumn{4}{|l|}{ Single Net } \\
\hline Double Net & & $9,680.00$ & 1 \\
\hline \multicolumn{4}{|l|}{ Straw w/ Tackifier } \\
\hline \begin{tabular}{|l|l} 
Straw \\
\end{tabular} & & & \multirow{2}{*}{ d } \\
\hline Tackifier & & & \\
\hline \multicolumn{4}{|l|}{ Soil Amendments: } \\
\hline \multicolumn{4}{|l|}{ Fertilizer } \\
\hline \multicolumn{4}{|l|}{ Agricultural Limestone } \\
\hline \multicolumn{4}{|l|}{ Dry Limestone } \\
\hline \multicolumn{4}{|l|}{ Liquid Limestone } \\
\hline \multicolumn{4}{|l|}{ Topsoil } \\
\hline \multicolumn{4}{|l|}{ Biological Growth Stimulants } \\
\hline \multicolumn{2}{|l|}{ Hydraulic Growth Medium } & & \\
\hline Organic Matter Component & & & \\
\hline Soil Stabilizer & & & \\
\hline \multicolumn{4}{|l|}{ Soil Test Results: } \\
\hline \multicolumn{4}{|l|}{ Fertilizer } \\
\hline $10-20-0$ & 0.25 tons/acre & & $\mathrm{i}$ \\
\hline \multicolumn{4}{|l|}{ Agricultural Limestone } \\
\hline \multicolumn{4}{|l|}{ Hydraulic Growth Medium } \\
\hline Organic Matter Component & $4500 \mathrm{lbs} / \mathrm{acre}$ & \multirow{2}{*}{$\$ 93,500.00$} & \\
\hline Soil Stabilizer & $70 \mathrm{lbs} / \mathrm{acre}$ & & \\
\hline
\end{tabular}

Figure 16: 2791B cost analysis output 


\begin{tabular}{|c|c|c|c|c|}
\hline \multicolumn{5}{|c|}{ Area 3} \\
\hline Type of Material & Application Rate & & Price & Notes \\
\hline \multicolumn{5}{|l|}{ Seed Type: } \\
\hline Developed Type C & $85 \mathrm{lbs} / \mathrm{acre}$ & $\$$ & 194.80 & \\
\hline \multicolumn{5}{|l|}{ Mulch Type: } \\
\hline \multicolumn{5}{|l|}{ Hydraulic Erosion Control Product } \\
\hline \multicolumn{5}{|l|}{ HECP Type 1} \\
\hline \multicolumn{5}{|l|}{ HЕСР Tyре 2} \\
\hline HECP Type 3 & $4000 \mathrm{lbs} / \mathrm{acre}$ & $\$$ & $7,438.00$ & \\
\hline \multicolumn{5}{|l|}{ Rolled Erosion Control Product } \\
\hline \multicolumn{5}{|l|}{ Single Net } \\
\hline \multicolumn{5}{|l|}{\begin{tabular}{l|l} 
Double Net \\
\end{tabular}} \\
\hline \multicolumn{5}{|l|}{ Straw w/ Tackifier } \\
\hline \begin{tabular}{|l|l|} 
Straw \\
\end{tabular} & 2 tons/acre & \multirow{2}{*}{$\$$} & \multirow{2}{*}{$1,125.00$} & \multirow{2}{*}{1} \\
\hline Tackifier & $250 \mathrm{lbs} / \mathrm{acre}$ & & & \\
\hline \multicolumn{5}{|l|}{ Soil Amendments: } \\
\hline \multicolumn{5}{|l|}{ Fertilizer } \\
\hline \multicolumn{5}{|l|}{ Agricultural Limestone } \\
\hline \multicolumn{5}{|l|}{ Dry Limestone } \\
\hline \multicolumn{5}{|l|}{ Liquid Limestone } \\
\hline \multicolumn{5}{|l|}{ Topsoil } \\
\hline \multicolumn{5}{|l|}{ Biological Growth Stimulants } \\
\hline \multicolumn{5}{|l|}{ Hydraulic Growth Medium } \\
\hline \multicolumn{5}{|l|}{ Organic Matter Component } \\
\hline \multicolumn{5}{|l|}{ Soil Stabilizer } \\
\hline \multicolumn{5}{|l|}{ Soil Test Results: } \\
\hline \multicolumn{5}{|l|}{ Fertilizer } \\
\hline \begin{tabular}{l|l} 
& $10-18-6$ \\
\end{tabular} & 0.25 tons/acre & & & $\mathrm{i}$ \\
\hline Agricultural Limestone & & & & j \\
\hline \multicolumn{5}{|l|}{ Hydraulic Growth Medium } \\
\hline Organic Matter Component & $4500 \mathrm{lbs} / \mathrm{acre}$ & $\varepsilon$ & 1675000 & \\
\hline Soil Stabilizer & $70 \mathrm{lbs} / \mathrm{acre}$ & & $40,150.00$ & \\
\hline
\end{tabular}

Figure 17: 279S2 cost analysis output 


\begin{tabular}{|c|c|c|}
\hline \multicolumn{3}{|c|}{ Totals } \\
\hline \multicolumn{3}{|l|}{ Seeds } \\
\hline \begin{tabular}{|l|l|} 
& Developed Type A \\
\end{tabular} & $\$$ & - \\
\hline Developed Type B & $\$$ & $3,295.00$ \\
\hline Developed Type C & $\$$ & 195.00 \\
\hline Developed Type E & $\$$ & - \\
\hline \multicolumn{3}{|l|}{ Mulches } \\
\hline \multicolumn{3}{|l|}{ User Inputted Option } \\
\hline HECP Type 1 & $\$$ & - \\
\hline HECP Type 2 & $\$$ & - \\
\hline HECP Type 3 & $\$$ & $22,314.00$ \\
\hline Single Net RECP & $\$$ & - \\
\hline Double Net RECP & $\$$ & $9,680.00$ \\
\hline Straw & $\$$ & $1,125.00$ \\
\hline \multicolumn{3}{|l|}{ Soil Amendments } \\
\hline \begin{tabular}{|l|l|} 
Fertilizer \\
\end{tabular} & $\$$ & - \\
\hline Agricultural Limestone & $\$$ & - \\
\hline Dry Limestone & $\$$ & - \\
\hline Liquid Limestone & $\$$ & - \\
\hline Topsoil & $\$$ & - \\
\hline Biological Growth Stimulants & $\$$ & - \\
\hline $\begin{array}{ll}\text { Hydraulic Growth Medium } \\
\end{array}$ & $\$$ & - \\
\hline \multicolumn{3}{|l|}{ Soil Test Results } \\
\hline \begin{tabular}{|l|l|} 
Fertilizer \\
\end{tabular} & $\$$ & - \\
\hline Agricultural Lime & $\$$ & - \\
\hline Hydraulic Growth Medium & $\$$ & $280,500.00$ \\
\hline
\end{tabular}

Figure 18: Route 279 cost analysis totals

\subsection{3: Corridor H Sites}

\subsubsection{1: Field Site Description}

The Corridor $\mathrm{H}$ sites were located at various locations along Corridor $\mathrm{H}$. The first site was located on U.S. Route 48 approximately 1 mile $(1.6 \mathrm{~km})$ from the intersection of WV Route 92 and U.S. Route 48 (N 38 57' 24.3", W 79 51' 8.9"), which shall be called CHS1 (Figure 19). The second site had three different areas associated with it. It was located approximately 2,500 $\mathrm{ft}(762 \mathrm{~m}$ ) from the current end of Corridor H near Kerens, WV (N 3900' 15.2", W 79 48' 47.7"). Two of the areas were located on either side of the highway in the cuts/fills areas, and the third was located in the median of the highway. The sites were named CHS2A (Figure 20), CHS2B (Figure 21), and CHMD (Figure 22), respectively. The third site was located along Corridor $\mathrm{H}$ on the section that currently runs from Davis, WV to Wardensville, WV (N $38^{\circ} 59^{\prime}$ 22.9", W $\left.79^{\circ} 50^{\prime} 15.2^{\prime \prime}\right)$. The third site contained two different areas. The first area was located on a cut on the side of the highway and is named CHS3 (Figure 23). The second area was located in the median and is named CHMD2 (Figure 24) (Hopkinson et al. 2016). These three sites along Corridor $\mathrm{H}$ are examples of how much soil can change along the alignment of a new highway construction. 


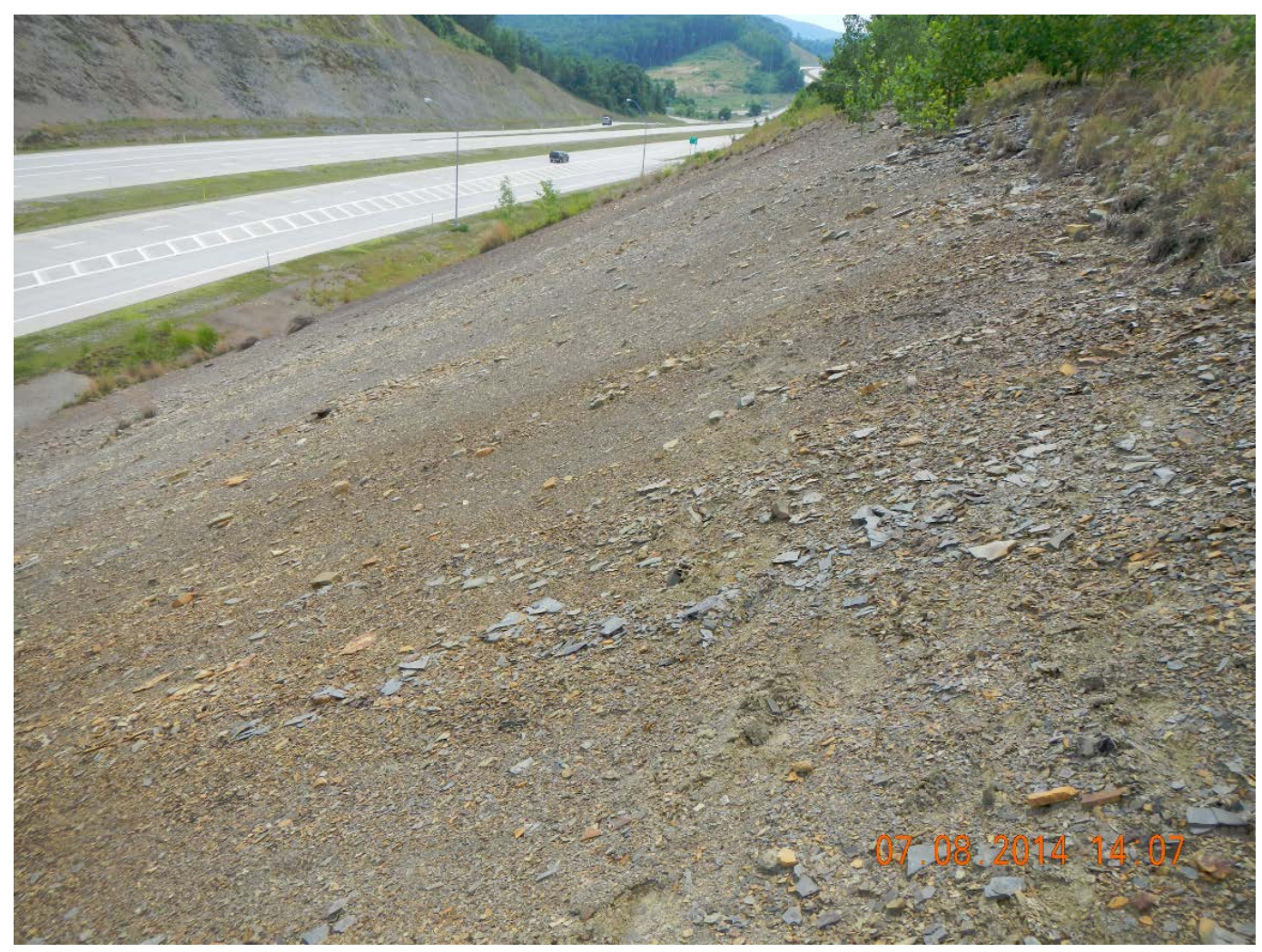

Figure 19: CHS1 site

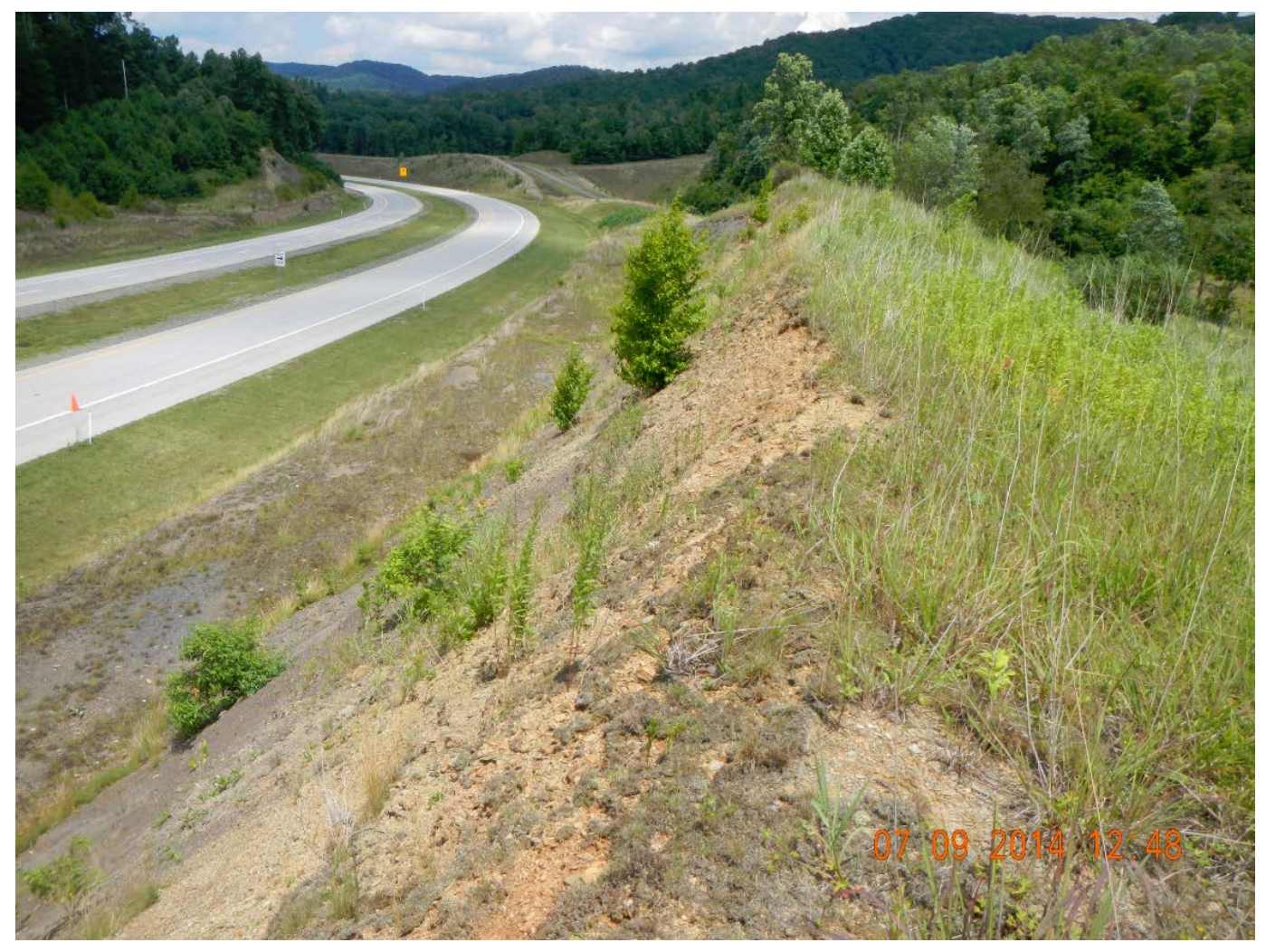

Figure 20: CHS2A site 


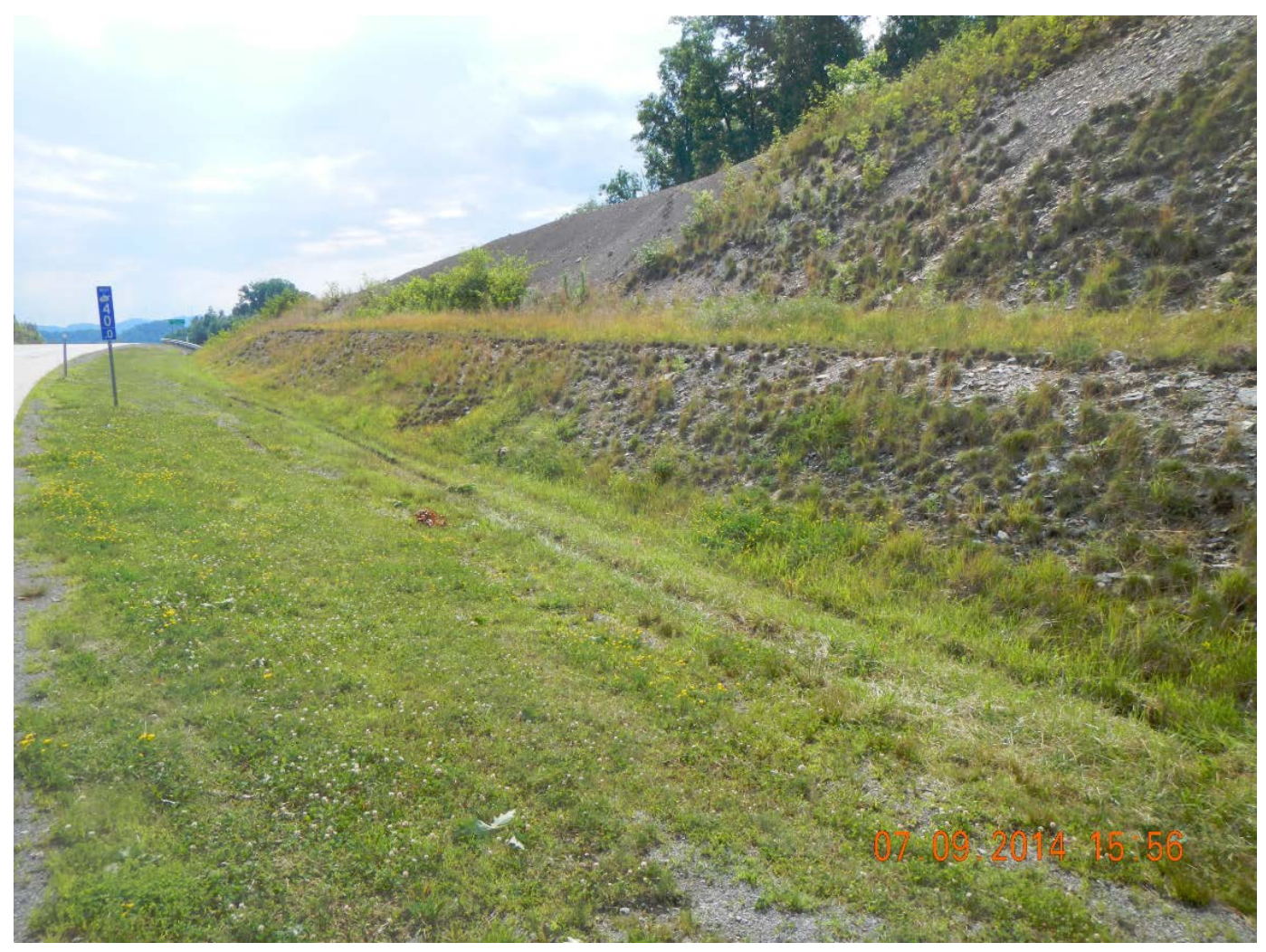

Figure 21: CHS2B site

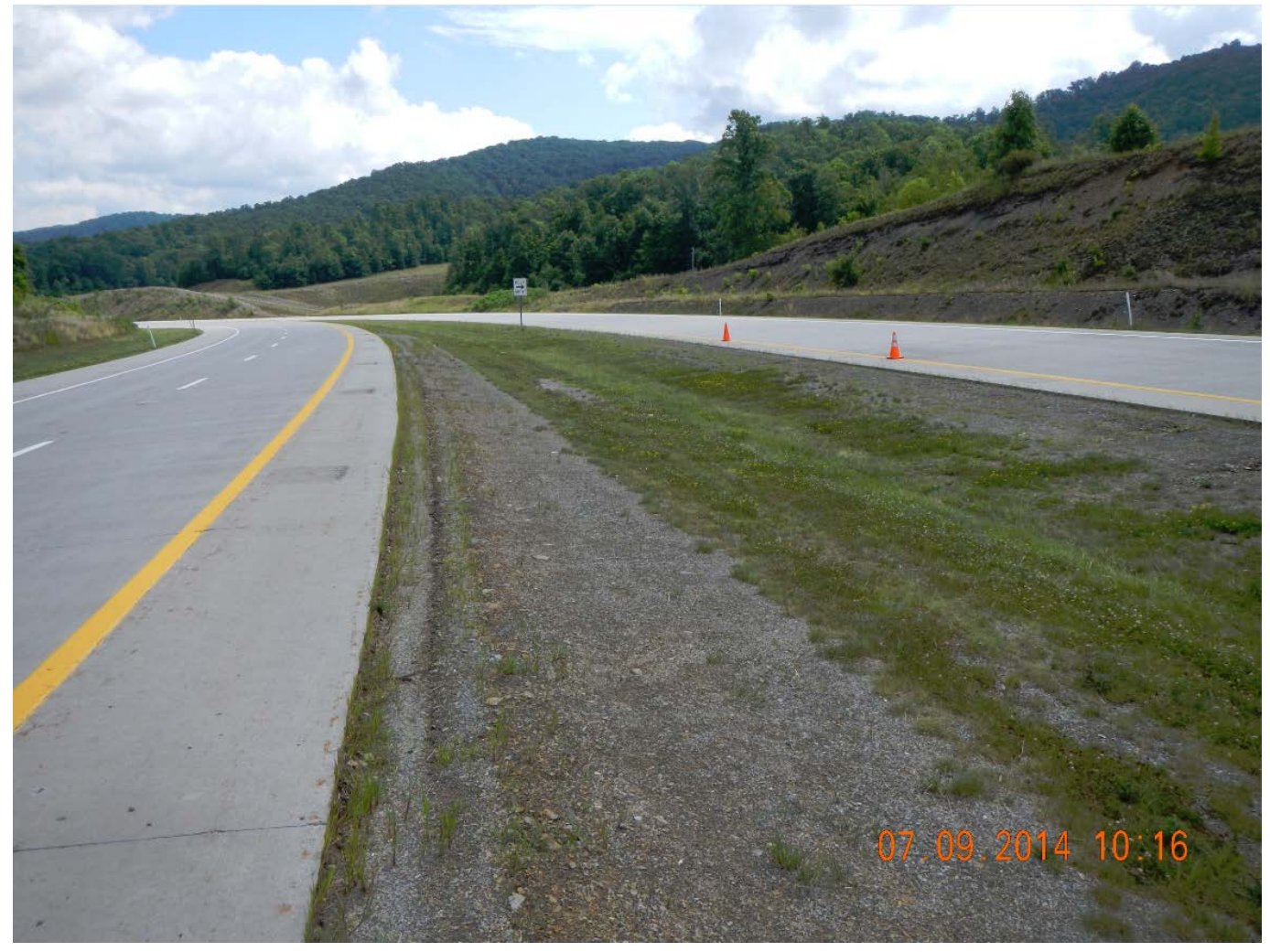

Figure 22: CHMD site 


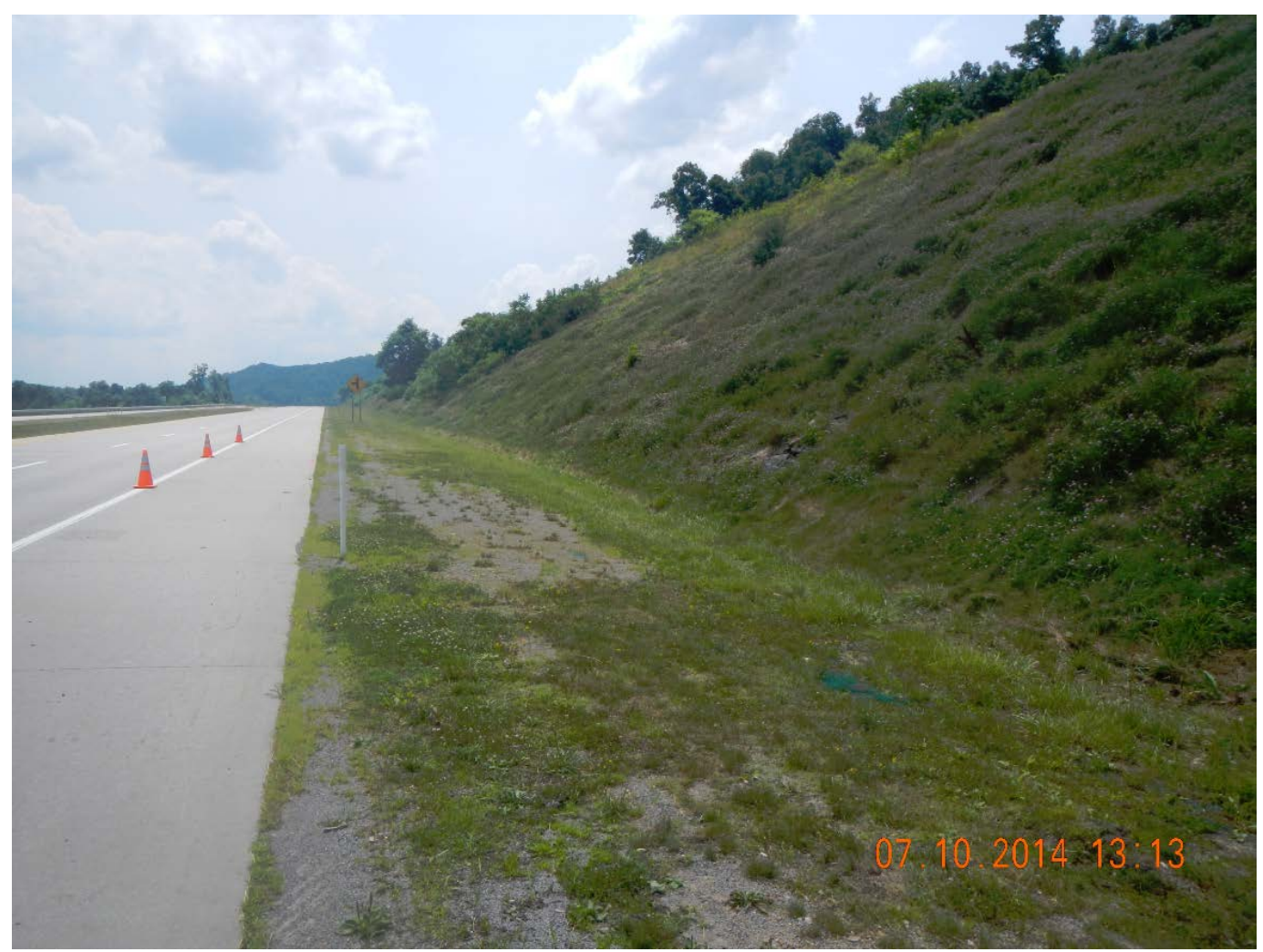

Figure 23: CHS3 site

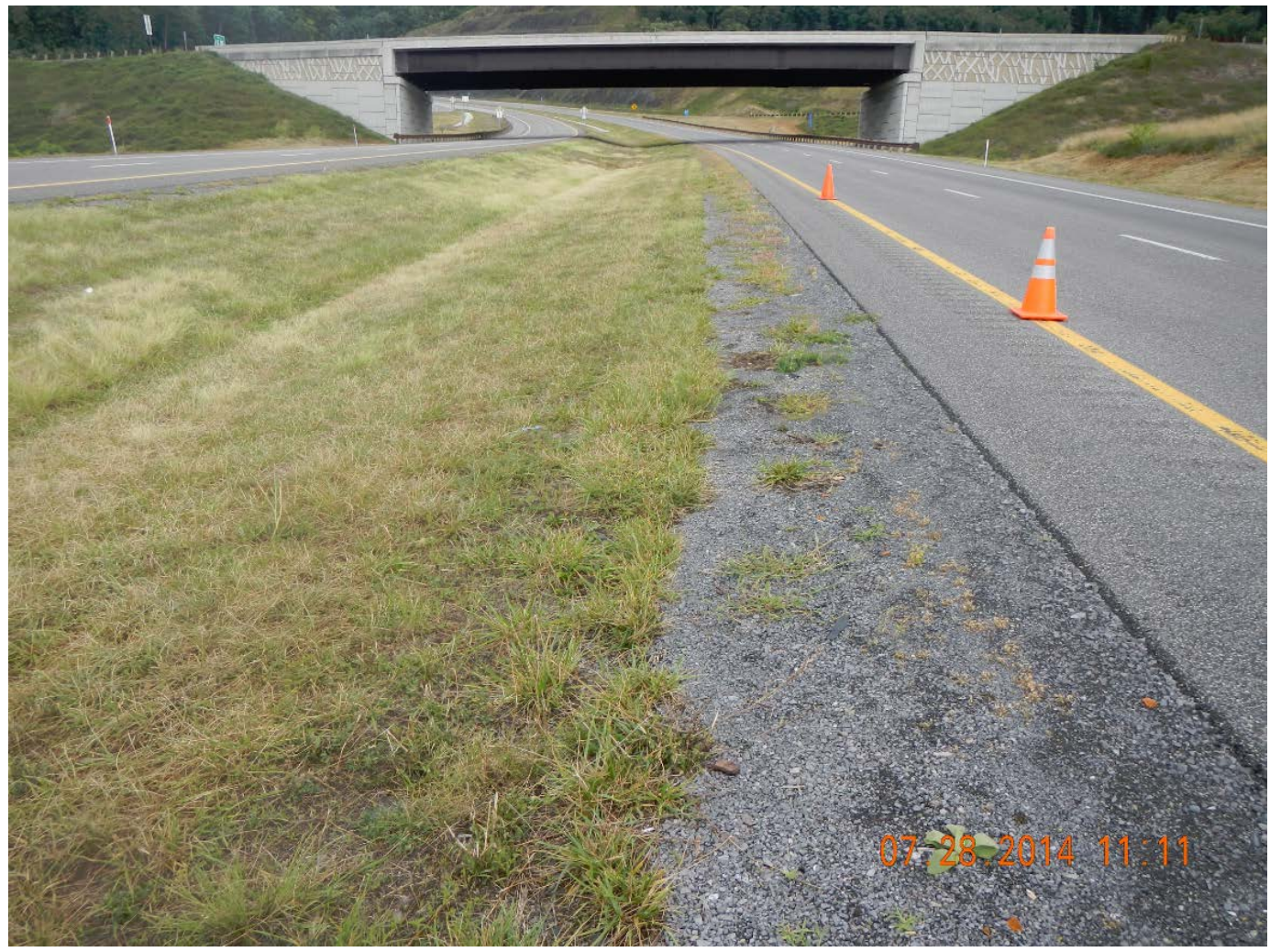

Figure 24: CHMD2 site 
The site had a soil test performed by AgSource Laboratories located in Lincoln, NE. The results from the soil test can be found in Table 13. No soil amendment recommendations were requested for the sites as these sites already had established vegetation.

Table 13: Corridor $\mathrm{H}$ soil test results

\begin{tabular}{|c|c|c|c|c|c|c|c|c|c|c|}
\hline $\begin{array}{c}\text { Site } \\
\text { Name }\end{array}$ & $\begin{array}{c}\text { Soil } \\
\text { Type }\end{array}$ & $\%$ Clay & \% Sand & \% Silt & $\% \mathrm{OM}$ & $\mathrm{pH}$ & $\begin{array}{c}\text { Buffer } \\
\mathrm{pH}\end{array}$ & $\mathrm{N} \mathrm{ppm}$ & $\mathrm{P}$ ppm & $\mathrm{K}$ ppm \\
\hline CHS1 & $\begin{array}{c}\text { Sandy } \\
\text { Loam }\end{array}$ & 4.4 & 59.6 & 36 & 1.6 & 4 & 5.5 & 2 & 3 & 92 \\
\hline CHS2A & $\begin{array}{l}\text { Sandy } \\
\text { Loam }\end{array}$ & 14.4 & 55.6 & 30 & 1.7 & 4.8 & 6.3 & 2 & 5 & 116 \\
\hline CHS2B & Loam & 10.4 & 47.6 & 42 & 1.6 & 5.7 & 6.9 & 1 & 13 & 92 \\
\hline CHMD & $\begin{array}{l}\text { Sandy } \\
\text { Loam }\end{array}$ & 14.4 & 57.6 & 28 & 1.7 & 7.6 & 7.5 & 4 & 6 & 75 \\
\hline CHS3 & $\begin{array}{l}\text { Sandy } \\
\text { Loam }\end{array}$ & 12.4 & 59.6 & 28 & 4.3 & 6.8 & 7.5 & 17 & 6 & 197 \\
\hline CHMD2 & Loam & 24.4 & 43.6 & 32 & 2 & 7 & 7.5 & 3 & 44 & 126 \\
\hline
\end{tabular}

Slope was measured at the site with a Suunto PM-5 Clinometer (Hopkinson et al. 2016). The mean slopes at each area in the site can be found in Table 14. The slopes for CHS1 and CHS2B were rounded to $2 \mathrm{H}: 1 \mathrm{~V}$. The slopes for $\mathrm{CHS} 2 \mathrm{~A}$ and $\mathrm{CHS} 3$ were rounded to $1.5 \mathrm{H}: 1 \mathrm{~V}$. The slope for CHMD was classified into the "Flat" category for the program.

Table 14: Slope results for Corridor H

\begin{tabular}{|c|c|c|}
\hline Site Name & Slope (\%) & Slope $(\mathrm{H}: \mathrm{V})$ \\
\hline CHS1 & 43.7 & $2.3 \mathrm{H}: 1 \mathrm{~V}$ \\
\hline CHS2A & 62.8 & $1.6 \mathrm{H}: 1 \mathrm{~V}$ \\
\hline CHS2B & 46.6 & $2.1 \mathrm{H}: 1 \mathrm{~V}$ \\
\hline CHMD & 9.3 & $10.8 \mathrm{H}: 1 \mathrm{~V}$ \\
\hline CHS3 & 52.2 & $1.9 \mathrm{H}: 1 \mathrm{~V}$ \\
\hline CHMD2 & 24.8 & $4 \mathrm{H}: 1 \mathrm{~V}$ \\
\hline
\end{tabular}

\subsubsection{2: Program Input}

The data collected was entered into the input sheet of the program to determine a cost analysis of seeding and mulching the six areas located on the Corridor $\mathrm{H}$ sites. The information used in the program can be found in Figure 25 and Figure 26. Area 1 corresponds to CHS1, Area 2 to CHS2A, Area 3 to CHS2B, Area 4 to CHMD, Area 5 to CHS3, and Area 6 to CHMD2. Each area was given an area of 1 acre (0.4 ha). The type of seed for the highway cuts/fills, CHS1, CHS2A, CHS2B, and CHS3, were chosen to be developed type B. The type of seed for the median areas, CHMD and CHMD2, were chosen to be developed type A. HECP mulch was 
chosen for CHS1 and CHS2A. RECP was chosen for CHS2B and CHS3. Straw mulch was chosen for CHMD and CHMD2.

\begin{tabular}{|c|c|c|c|c|c|}
\hline & \multicolumn{2}{|l|}{ Site Parameters } & Custom Price & \multicolumn{2}{|c|}{ Soil Test Results } \\
\hline \multirow{14}{*}{ Area 1} & Area (acres) & 1 & & $\mathrm{pH}$ & 4 \\
\hline & Slope (H:V) & $2: 1$ & & Buffer $\mathrm{pH}$ & 5.5 \\
\hline & Type of Seed & Developed Type B & & $\%$ Organic Matter & 1.6 \\
\hline & Type of Mulch & HECP & & Nitrogen $(\mathrm{ppm})$ & 2 \\
\hline & Mulch Application Rate (HECP-Ibs/acre) (Straw-tons/acre) & & & Phosphorus (ppm) & 3 \\
\hline & Fertilizer Required (tons/acre) & & & Potassium (ppm) & 92 \\
\hline & Fertilizer Type (N-P-K) & & & \%Clay & 4.4 \\
\hline & Agricultural Limestone Required (tons/acre) & & & $\%$ Silt & 59.6 \\
\hline & Dry Limestone Required (Ibs/acre) & & & \%Sand & 36 \\
\hline & Liquid Limestone Required (gallons/acre) & & & Soil Type & \\
\hline & Topsoil Required (cubic yards) & & & & \\
\hline & Biological Growth Stimulant Required (Ibs/acre) & & & & \\
\hline & Hydraulic Growth Medium Organic Component (Ibs/acre) & & & & \\
\hline & Hydraulic Growth Medium Soil Stabillizer (Ibs/acre) & & & & \\
\hline \multirow{14}{*}{ Area 2} & Area (acres) & 1 & & $\mathrm{pH}$ & 4.8 \\
\hline & Slope $(\mathrm{H}: \mathrm{V})$ & $1.5: 1$ & & Buffer pH & 6.3 \\
\hline & Type of Seed & Developed Type B & & $\%$ Organic Matter & 1.7 \\
\hline & Type of Mulch & HECP & & Nitrogen $(\mathrm{ppm})$ & 2 \\
\hline & Mulch Application Rate (HECP-Ibs/acre) (Straw-tons/acre) & & & Phosphorus (ppm) & 5 \\
\hline & Fertilizer Required (tons/acre) & & & Potassium (ppm) & 116 \\
\hline & Fertilizer Type (N-P-K) & & & \%Clay & 14.4 \\
\hline & Agricultural Limestone Required (tons/acre) & & & \%Silt & 55.6 \\
\hline & Dry Limestone Required (Ibs/acre) & & & \%Sand & 30 \\
\hline & Liquid Limestone Required (gallons/acre) & & & Soil Type & \\
\hline & Topsoil Required (cubic yards) & & & & \\
\hline & Biological Growth Stimulant Required (Ibs/acre) & & & & \\
\hline & Hydraulic Growth Medium Organic Component (Ibs/acre) & & & & \\
\hline & Hydraulic Growth Medium Soil Stabilizer (Ibs/acre) & & & & \\
\hline \multirow{14}{*}{ Area 3} & Area (acres) & 1 & & $\mathrm{pH}$ & 5.7 \\
\hline & Slope $(\mathrm{H}: \mathrm{V})$ & $2: 1$ & & Buffer $\mathrm{pH}$ & 6.9 \\
\hline & Type of Seed & Developed Type B & & $\%$ Organic Matter & 1.6 \\
\hline & Type of Mulch & RECP & & Nitrogen (ppm) & 1 \\
\hline & Mulch Application Rate (HECP-Ibs/acre) (Straw-tons/acre) & & & Phosphorus (ppm) & 13 \\
\hline & Fertilizer Required (tons/acre) & & & \begin{tabular}{|l|} 
Potassium (ppm) \\
\end{tabular} & 92 \\
\hline & Fertilizer Type (N-P-K) & & & \%Clay & 10.4 \\
\hline & Agricultural Limestone Required (tons/acre) & & & \%Silt & 47.6 \\
\hline & Dry Limestone Required (Ibs/acre) & & & \%Sand & 42 \\
\hline & Liquid Limestone Required (gallons/acre) & & & Soil Type & \\
\hline & Topsoil Required (cubic yards) & & & & \\
\hline & Biological Growth Stimulant Required (Ibs/acre) & & & & \\
\hline & Hydraulic Growth Medium Organic Component (Ibs/acre) & & & & \\
\hline & Hydraulic Growth Medium Soil Stabilizer (Ibs/acre) & & & & \\
\hline
\end{tabular}

Figure 25: Corridor $\mathrm{H}$ areas 1-3 input 


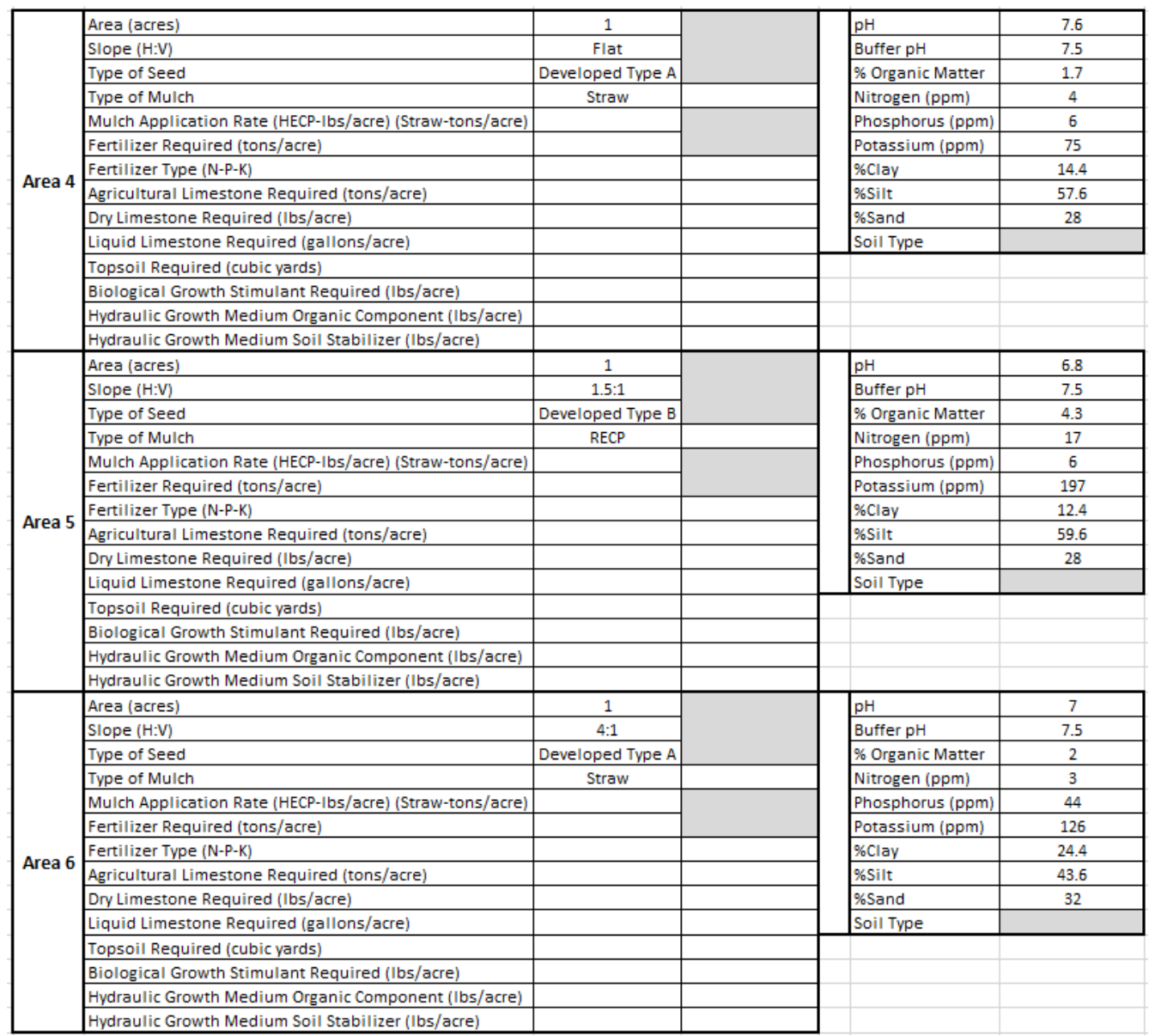

Figure 26: Corridor $\mathrm{H}$ areas 4-6 input

\subsubsection{3: Program Output}

After the program was run, the output sheet was printed. Area 1, or CHS1, can be found in Figure 27, Area 2, or CHS2A, can be found in Figure 28, Area 3, or CHS2B, can be found in Figure 29, Area 4, or CHMD, can be found in Figure 30, Area 5, or CHS3, can be found in Figure 31, and Area 6, or CHMD2, can be found in Figure 32. These outputs show the cost of using the specified materials in the program input as shown in the previous section.

The seed type chosen for CHS1, CHS2A, CHS2B, and CHS3 was developed type B. This seed mixture has planting dates between March $1^{\text {st }}$ and June $20^{\text {th }}$ and again from October $1^{\text {st }}$ to October $31^{\text {st }}$. The planting date that was chosen was September $1^{\text {st }}, 2017$ as shown in Figure 27. The planting date was out of the range of the planting dates for developed type $B$ seed mixture so the program printed a note for the user. The seed type chosen for CHMD and CHMD2 was developed type A. This seed mixture has planting dates of February $15^{\text {th }}$ to June $20^{\text {th }}$ and August $1^{\text {st }}$ to October $31^{\text {st }}$. The planting date was in these date ranges so no special note "a" was included for these areas.

The mulch type calculated in areas CHS1 and CHS2A was HECP. RECP mulch was used for areas CHS2B and CHS3. Straw mulch was used for the two median areas, CHMD and 
CHMD2. For areas CHS1 and CHS2A the cheapest option for mulch was straw mulch. It should be taken into consideration by the user that although straw mulch may be the cheapest option for the area, it may be more feasible to use HECP or RECP mulch because the area is at a $2 \mathrm{H}: 1 \mathrm{~V}$ slope. For areas CHS2A and CHS2B, RECP was the cheapest option and straw mulch was not calculated because straw mulch cannot be applied to a slope greater than $2 \mathrm{H}: 1 \mathrm{~V}$. For area CHMD, the cheapest option is to use the RECP although the difference between straw mulch and HECP is very small (\$106.25), either could be used at the discretion of the user. For area CHMD2, the cheapest option would be straw mulch. The price of HECP for this area is more than double the price of straw mulch because the slope $(4 \mathrm{H}: 1 \mathrm{~V})$ requires a higher type of HECP.

The program did not have any soil amendment recommendations in the input boxes so this section does not contain any data. The soil amendments that are recommended to be added to this site were calculated using the soil test results. The program calculated that area CHS1 should have a 10-20-6 fertilizer, areas CHS2A and CHMD should have a 10-18-6 fertilizer, area CHS2B should have a 10-15-6 fertilizer, area CHS3 should have a 10-18-0 fertilizer, and area CHMD2 should have a 10-6-6 fertilizer applied to it. The program calculated that all of these fertilizers should be applied at a rate of 0.25 tons/acre (560 kg/acre). The program did not calculate prices for the fertilizer because those types of fertilizer are not known by the program.

The program calculated that areas $\mathrm{CHS1}$ and $\mathrm{CHS} 2 \mathrm{~A}$ required agricultural limestone because of the low pH values (4 and 4.8, respectively). Both of these values are below the recommended $\mathrm{pH}$ value for developed type $\mathrm{B}$ seed mixture of 6.5. Although area $\mathrm{CHS} 2 \mathrm{~B}$ had a $\mathrm{pH}$ of 5.7, the program did not calculate a rate of agricultural limestone because the buffer $\mathrm{pH}$ was out of the range of the chart the program uses to calculate rates of limestone application. The other 3 areas in the program had a pH higher than 6.5 so limestone is not needed.

The program calculated that all of the areas except for CHS2A and $\mathrm{CHS} 3$ required the addition of a HGM. Area CHS2A cannot have a HGM applied because the slope is $1.5 \mathrm{H}: 1 \mathrm{~V}$ and a HGM cannot be applied to areas with a slope greater than $2 \mathrm{H}: 1 \mathrm{~V}$, as noted by note "g". Area CHS3 did not require the application of a HGM because the organic matter is $4.3 \%$ and greater than the minimum of $3 \%$ required by the revised specifications. The other areas, CHS1, CHS2B, CHMD, and CHMD2, all have organic matter below 3\%, requiring a HGM application. The program calculated the rates of the organic matter component and soil stabilizer according to the revised specifications.

The program totals can be found in Figure 33. The totals sheet sums up all of the price estimates for each material in each area. The only exception to this is the mulch section only totals up the user inputted option from each area. This allows for the user to have a total of each material or choose a few totals for different materials. 


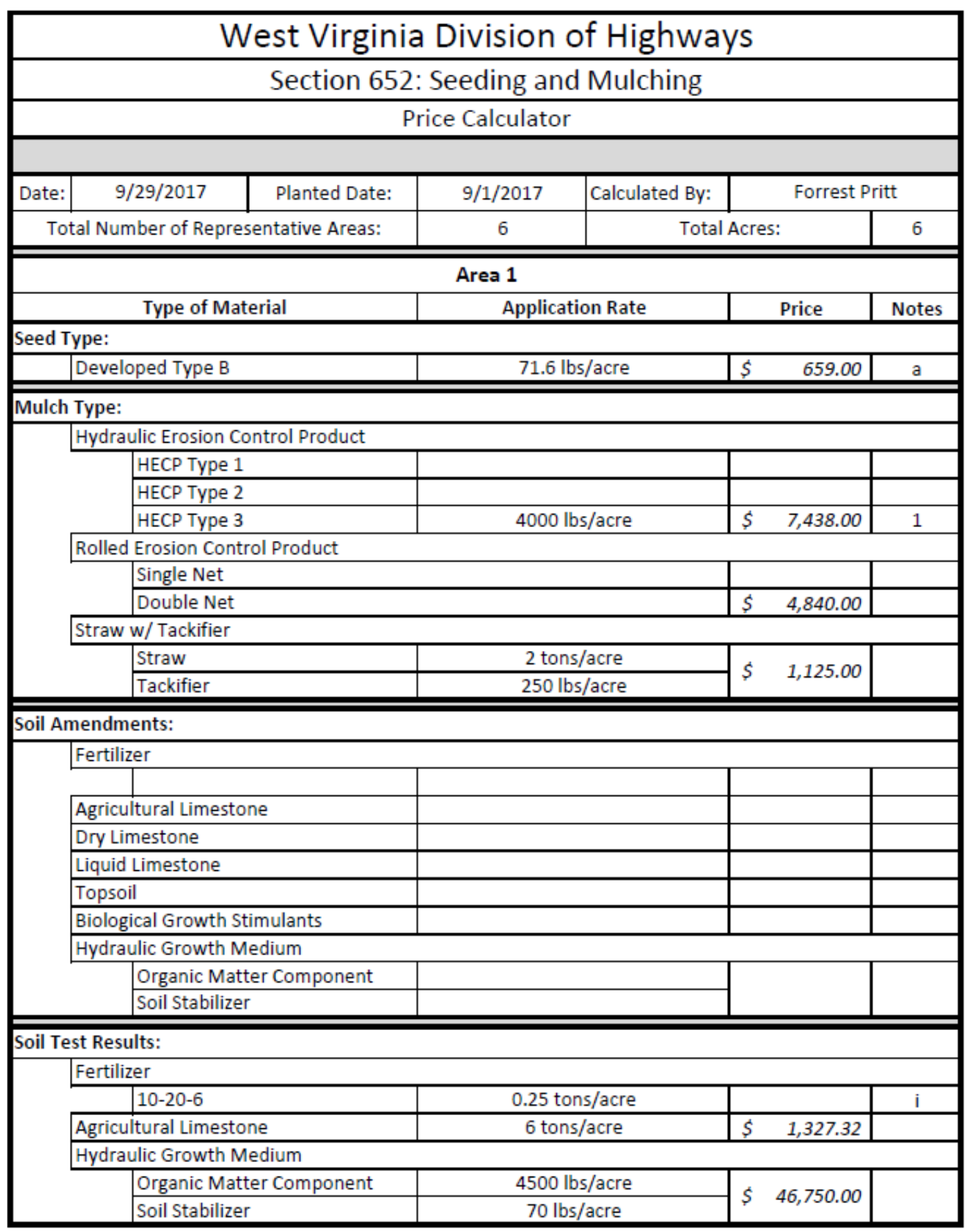

Figure 27: CHS1 cost analysis output 


\begin{tabular}{|c|c|c|c|}
\hline \multicolumn{4}{|c|}{ Area 2} \\
\hline Type of Material & Application Rate & Price & Notes \\
\hline \multicolumn{4}{|l|}{ Seed Type: } \\
\hline \begin{tabular}{|l|l|} 
& Developed Type B \\
\end{tabular} & $71.6 \mathrm{lbs} / \mathrm{acre}$ & 659.00 & a \\
\hline \multicolumn{4}{|l|}{ Mulch Type: } \\
\hline \multicolumn{4}{|l|}{\begin{tabular}{|l|l|} 
Hydraulic Erosion Control Product \\
\end{tabular}} \\
\hline \begin{tabular}{|l|l|} 
HECP Type 1 \\
\end{tabular} & & & \\
\hline HECP Type 2 & & & \\
\hline HECP Type 3 & $4000 \mathrm{lbs} / \mathrm{acre}$ & $7,438.00$ & 1 \\
\hline \multicolumn{4}{|l|}{ Rolled Erosion Control Product } \\
\hline \multicolumn{3}{|l|}{ Single Net } & \\
\hline & & $\$ \quad 4,840.00$ & \\
\hline \multicolumn{4}{|l|}{\begin{tabular}{|l}
\multicolumn{1}{c|}{ Double Net } \\
Straw w/ Tackifier
\end{tabular}} \\
\hline \begin{tabular}{l|l} 
Straw \\
\end{tabular} & & & \multirow{2}{*}{ c } \\
\hline Tackifier & & & \\
\hline \multicolumn{4}{|l|}{ Soil Amendments: } \\
\hline \multicolumn{4}{|l|}{\begin{tabular}{|l|l|} 
Fertilizer \\
\end{tabular}} \\
\hline & & & \\
\hline \multicolumn{4}{|l|}{ Agricultural Limestone } \\
\hline \multicolumn{4}{|l|}{ Dry Limestone } \\
\hline \multicolumn{4}{|l|}{ Liquid Limestone } \\
\hline \multicolumn{4}{|l|}{ Topsoil } \\
\hline \multicolumn{4}{|l|}{ Biological Growth Stimulants } \\
\hline \multicolumn{4}{|l|}{ Hydraulic Growth Medium } \\
\hline \begin{tabular}{l|l|} 
Organic Matter Component \\
\end{tabular} & & & \multirow{2}{*}{$\mathrm{g}$} \\
\hline Soil Stabilizer & & & \\
\hline \multicolumn{4}{|l|}{ Soil Test Results: } \\
\hline \multicolumn{4}{|l|}{\begin{tabular}{|l|l|} 
& Fertilizer \\
\end{tabular}} \\
\hline \begin{tabular}{l|l|} 
& $10-18-6$ \\
\end{tabular} & 0.25 tons/acre & & $\bar{i}$ \\
\hline \begin{tabular}{|l} 
Agricultural Limestone \\
\end{tabular} & 1 tons/acre & 221.22 & \\
\hline \multicolumn{4}{|l|}{ Hydraulic Growth Medium } \\
\hline \begin{tabular}{l|l|} 
Organic Matter Component \\
\cline { 2 - 2 }
\end{tabular} & & & \multirow{2}{*}{$\mathrm{g}$} \\
\hline Soil Stabilizer & & & \\
\hline
\end{tabular}

Figure 28: CHS2A cost analysis output 


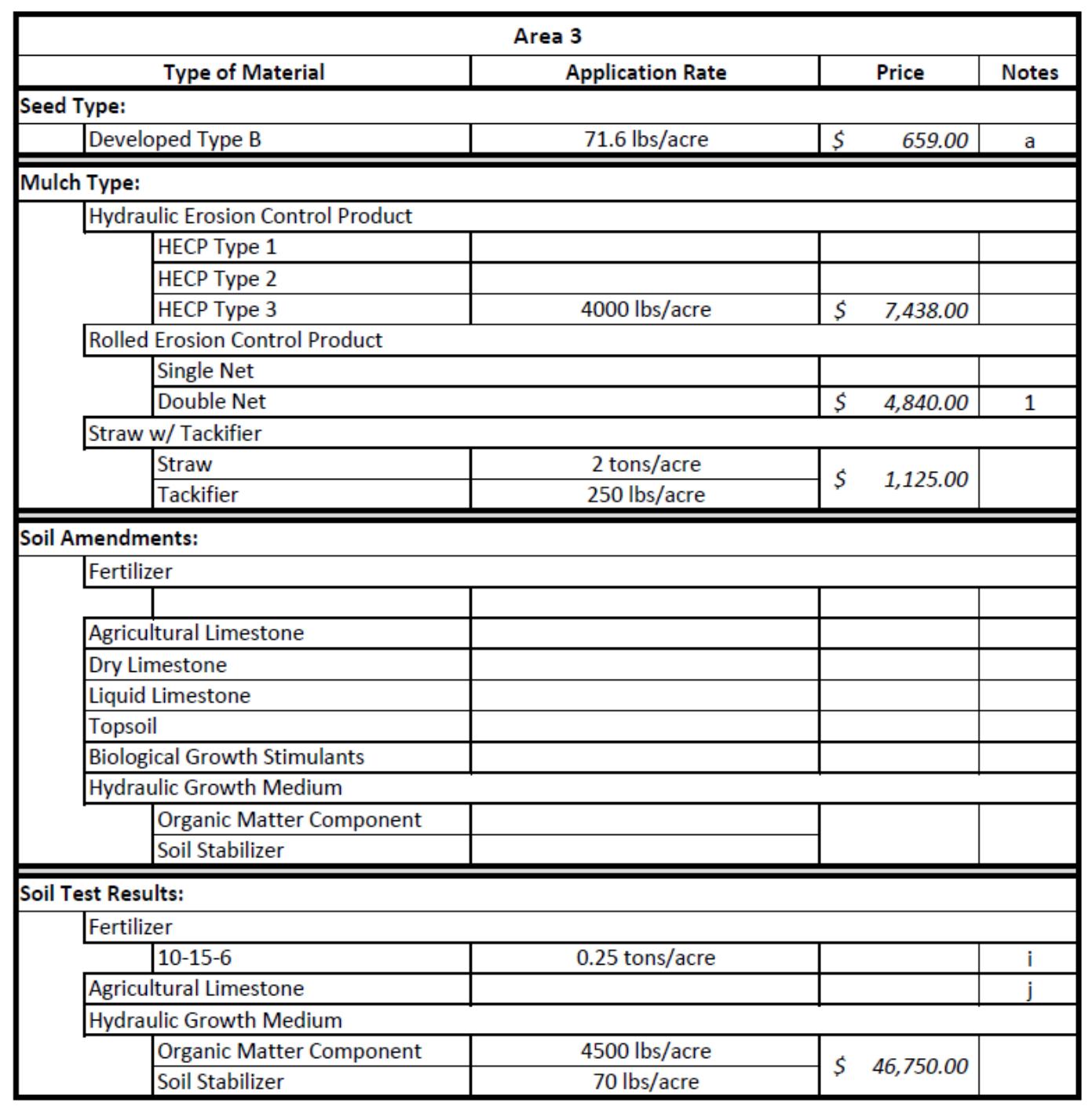

Figure 29: CHS2B cost analysis output 


\begin{tabular}{|c|c|c|c|}
\hline \multicolumn{4}{|c|}{ Area 4} \\
\hline Type of Material & Application Rate & Price & Notes \\
\hline \multicolumn{4}{|l|}{ Seed Type: } \\
\hline \begin{tabular}{|l|l|} 
& Developed Type A \\
\end{tabular} & $163.56 \mathrm{lbs} / \mathrm{acre}$ & 478.53 & \\
\hline \multicolumn{4}{|l|}{ Mulch Type: } \\
\hline \multicolumn{4}{|l|}{\begin{tabular}{|l|l|} 
Hydraulic Erosion Control Product \\
\end{tabular}} \\
\hline \begin{tabular}{|l|l|} 
HECP Type 1 \\
\end{tabular} & $2500 \mathrm{lbs} / \mathrm{acre}$ & $\$ \quad 1,018.75$ & \\
\hline HECP Type 2 & & & \\
\hline HECP Type 3 & & & \\
\hline \multicolumn{4}{|l|}{ Rolled Erosion Control Product } \\
\hline \multicolumn{4}{|l|}{\begin{tabular}{l|l|} 
Single Net \\
\end{tabular}} \\
\hline \multicolumn{4}{|l|}{ Double Net } \\
\hline \multicolumn{4}{|l|}{ Straw w/ Tackifier } \\
\hline \begin{tabular}{l|l|} 
Straw \\
\end{tabular} & 2 tons/acre & \multirow{2}{*}{$1,125.00$} & \multirow{2}{*}{1} \\
\hline Tackifier & $250 \mathrm{lbs} / \mathrm{acre}$ & & \\
\hline \multicolumn{4}{|l|}{ Soil Amendments: } \\
\hline \multicolumn{4}{|l|}{\begin{tabular}{|l|} 
Fertilizer \\
\end{tabular}} \\
\hline & & & \\
\hline \multicolumn{4}{|l|}{ Agricultural Limestone } \\
\hline \multicolumn{4}{|l|}{\begin{tabular}{|l} 
Dry Limestone \\
\end{tabular}} \\
\hline \multicolumn{4}{|l|}{ Liquid Limestone } \\
\hline \multicolumn{4}{|l|}{ Topsoil } \\
\hline \multicolumn{4}{|l|}{ Biological Growth Stimulants } \\
\hline \multicolumn{4}{|l|}{ Hydraulic Growth Medium } \\
\hline \begin{tabular}{|l|l|} 
& Organic Matter Component \\
\cline { 2 - 2 }
\end{tabular} & & & \\
\hline Soil Stabilizer & & & \\
\hline \multicolumn{4}{|l|}{ Soil Test Results: } \\
\hline \multicolumn{4}{|l|}{\begin{tabular}{|l|l|} 
Fertilizer \\
\end{tabular}} \\
\hline \begin{tabular}{l|l|} 
& $10-18-6$ \\
\end{tabular} & 0.25 tons/acre & & $\mathrm{i}$ \\
\hline \multicolumn{4}{|l|}{ Agricultural Limestone } \\
\hline \multicolumn{4}{|l|}{ Hydraulic Growth Medium } \\
\hline \begin{tabular}{|l|l|} 
Organic Matter Component \\
\cline { 2 - 2 }
\end{tabular} & $4000 \mathrm{lbs} / \mathrm{acre}$ & & \\
\hline Soil Stabilizer & $35 \mathrm{lbs} / \mathrm{acre}$ & $40,8 / 5.00$ & \\
\hline
\end{tabular}

Figure 30: CHMD cost analysis output 


\begin{tabular}{|c|c|c|c|}
\hline \multicolumn{4}{|c|}{ Area 5} \\
\hline Type of Material & Application Rate & Price & Notes \\
\hline \multicolumn{4}{|l|}{ Seed Type: } \\
\hline Developed Type B & $71.6 \mathrm{lbs} / \mathrm{acre}$ & 659.00 & a \\
\hline \multicolumn{4}{|l|}{ Mulch Type: } \\
\hline \multicolumn{4}{|l|}{ Hydraulic Erosion Control Product } \\
\hline \begin{tabular}{|l|l|} 
HECP Type 1 \\
\cline { 2 - 2 }
\end{tabular} & & & \\
\hline HECP Type 2 & & & \\
\hline HECP Type 3 & $4000 \mathrm{lbs} / \mathrm{acre}$ & $7,438.00$ & \\
\hline \multicolumn{4}{|l|}{ Rolled Erosion Control Product } \\
\hline \multicolumn{4}{|l|}{ Single Net } \\
\hline Double Net & & $\$ \quad 4,840.00$ & 1 \\
\hline \multicolumn{4}{|l|}{ Straw w/ Tackifier } \\
\hline \begin{tabular}{|l|l|} 
Straw \\
\end{tabular} & & & \multirow{2}{*}{ c } \\
\hline Tackifier & & & \\
\hline \multicolumn{4}{|l|}{ Soil Amendments: } \\
\hline \multicolumn{4}{|l|}{ Fertilizer } \\
\hline & & & \\
\hline \multicolumn{4}{|l|}{ Agricultural Limestone } \\
\hline \multicolumn{4}{|l|}{\begin{tabular}{|l} 
Dry Limestone \\
\end{tabular}} \\
\hline \multicolumn{4}{|l|}{ Liquid Limestone } \\
\hline \multicolumn{4}{|l|}{\begin{tabular}{|l|} 
Topsoil \\
\end{tabular}} \\
\hline \multicolumn{4}{|l|}{ Biological Growth Stimulants } \\
\hline \multicolumn{4}{|l|}{ Hydraulic Growth Medium } \\
\hline Organic Matter Component & & & \multirow{2}{*}{$\mathrm{g}$} \\
\hline Soil Stabilizer & & & \\
\hline \multicolumn{4}{|l|}{ Soil Test Results: } \\
\hline \multicolumn{4}{|l|}{\begin{tabular}{|l|l|} 
Fertilizer \\
\end{tabular}} \\
\hline \begin{tabular}{l|l} 
& $10-18-0$ \\
\end{tabular} & 0.25 tons/acre & & $\mathrm{i}$ \\
\hline \multicolumn{4}{|l|}{ Agricultural Limestone } \\
\hline \multicolumn{4}{|l|}{ Hydraulic Growth Medium } \\
\hline \begin{tabular}{|l|l|} 
& Organic Matter Component \\
\end{tabular} & & & \multirow{2}{*}{$\mathrm{g}$} \\
\hline Soil Stabilizer & & & \\
\hline
\end{tabular}

Figure 31: CHS3 cost analysis output 


\begin{tabular}{|c|c|c|c|c|}
\hline \multicolumn{5}{|c|}{ Area 6} \\
\hline Type of Material & Application Rate & & Price & Notes \\
\hline \multicolumn{5}{|l|}{ Seed Type: } \\
\hline \begin{tabular}{|l|l|} 
& Developed Type A \\
\end{tabular} & $163.56 \mathrm{lbs} / \mathrm{acre}$ & $\$$ & 478.53 & \\
\hline \multicolumn{5}{|l|}{ Mulch Type: } \\
\hline \multicolumn{5}{|l|}{\begin{tabular}{|l|l} 
Hydraulic Erosion Control Product \\
\cline { 2 - 3 }
\end{tabular}} \\
\hline \begin{tabular}{|l|l} 
HECP Type 1 \\
\cline { 2 - 2 }
\end{tabular} & & & & \\
\hline HECP Type 2 & $3000 \mathrm{lbs} / \mathrm{acre}$ & $\$$ & $3,000.00$ & \\
\hline HЕCР Type 3 & & & & \\
\hline \multicolumn{5}{|l|}{ Rolled Erosion Control Product } \\
\hline \multicolumn{5}{|l|}{ Single Net } \\
\hline \multicolumn{5}{|l|}{\begin{tabular}{|l} 
Double Net \\
\end{tabular}} \\
\hline \multicolumn{5}{|l|}{ Straw w/ Tackifier } \\
\hline \begin{tabular}{|l|l|} 
Straw \\
\end{tabular} & 2 tons/acre & \multirow{2}{*}{$\$$} & \multirow{2}{*}{$1,125.00$} & \multirow{2}{*}{1} \\
\hline Tackifier & $250 \mathrm{lbs} / \mathrm{acre}$ & & & \\
\hline \multicolumn{5}{|l|}{ Soil Amendments: } \\
\hline \multicolumn{5}{|l|}{ Fertilizer } \\
\hline & & & & \\
\hline \multicolumn{5}{|l|}{ Agricultural Limestone } \\
\hline \multicolumn{5}{|l|}{\begin{tabular}{|l} 
Dry Limestone \\
\end{tabular}} \\
\hline \multicolumn{5}{|l|}{ Liquid Limestone } \\
\hline \multicolumn{5}{|l|}{ Topsoil } \\
\hline \multicolumn{5}{|l|}{ Biological Growth Stimulants } \\
\hline \multicolumn{5}{|l|}{ Hydraulic Growth Medium } \\
\hline \multicolumn{5}{|l|}{\begin{tabular}{l|l|} 
& Organic Matter Component \\
\end{tabular}} \\
\hline \multicolumn{5}{|l|}{ Soil Stabilizer } \\
\hline \multicolumn{5}{|l|}{ Soil Test Results: } \\
\hline \multicolumn{5}{|l|}{ Fertilizer } \\
\hline \begin{tabular}{l|l|} 
& $10-6-6$ \\
\end{tabular} & 0.25 tons/acre & & & $\bar{i}$ \\
\hline \multicolumn{5}{|l|}{ Agricultural Limestone } \\
\hline \multicolumn{5}{|l|}{ Hydraulic Growth Medium } \\
\hline \begin{tabular}{|l|l|} 
Organic Matter Component \\
\end{tabular} & $4000 \mathrm{lbs} / \mathrm{acre}$ & $s$ & 1087500 & \\
\hline Soil Stabilizer & $35 \mathrm{lbs} / \mathrm{acre}$ & & $40,815.00$ & \\
\hline
\end{tabular}

Figure 32: CHMD2 cost analysis output 


\begin{tabular}{|c|c|c|}
\hline & & \\
\hline Seeds & & \\
\hline \begin{tabular}{l|l} 
Developed Type A \\
\end{tabular} & $\$$ & 958.00 \\
\hline Developed Tyре B & $\bar{S}$ & $2,636.00$ \\
\hline Developed Type C & $\$$ & - \\
\hline Developed Type E & $\$$ & - \\
\hline Mulches & & \\
\hline User Inputted Option & & \\
\hline \begin{tabular}{l|l} 
HECP Type 1 \\
\end{tabular} & $\$$ & - \\
\hline HECP Type 2 & $\$$ & - \\
\hline HECP Type 3 & $\$$ & $14,876.00$ \\
\hline Single Net RECP & $\$$ & - \\
\hline Double Net RECP & $\$$ & $9,680.00$ \\
\hline Straw & $\$$ & $2,250.00$ \\
\hline Soil Amendments & & \\
\hline \begin{tabular}{l|l} 
Fertilizer \\
\cline { 2 - 2 }
\end{tabular} & $\$$ & - \\
\hline Agricultural Limestone & $\$$ & - \\
\hline Dry Limestone & $\$$ & - \\
\hline Liquid Limestone & $\$$ & - \\
\hline Topsoil & $\$$ & - \\
\hline Biological Growth Stimulants & $\$$ & - \\
\hline Hydraulic Growth Medium & $\$$ & - \\
\hline Soil Test Results & & \\
\hline \begin{tabular}{|l|l|} 
& Fertilizer \\
\cline { 2 - 2 }
\end{tabular} & $\$$ & - \\
\hline Agricultural Lime & $\$$ & $1,548.00$ \\
\hline Hydraulic Growth Medium & $\$$ & $175,250.00$ \\
\hline
\end{tabular}

Figure 33: Corridor H cost analysis totals

\subsection{Conclusions}

This research developed the Materials Estimate tool for the revised specifications recommended for the WVDOH. The tool calculates the cost of materials in the revised specifications and provides recommendations for application of different materials on a construction site. The tool allows for a user to create a custom cost estimate for pre-bid or final cost calculations on a construction site.

The tool takes primary and secondary information about a construction site. The primary inputs include: number of planting areas, size of each area, slope, type of seed, and type of mulch. The secondary inputs include information about soil amendments and soil test results. The primary inputs are the minimum information needed to create a cost estimate for seed and mulching while the secondary inputs help fine tune the cost estimate according to the preexisting soil conditions in an area.

The tool was tested with three different case studies of existing sites along highways in West Virginia. The tool calculated the cost of applying the revised specifications of seeding and mulching to the sites according to their primary information and soil test results. The tool 
demonstrated the ability to handle information from multiple areas in a construction site and provide the recommendations to the user in a concise manner.

The tool should be used by anyone wanting to use the revised specifications for permanent seeding and mulching. It is constructed to be able to be used by anyone that is familiar with the revised specifications. The tool is made to be modified as new BMPs become available and can also accept new seed mixtures or mulching practices. 


\section{Ch. 4: Conclusions and Discussion}

\section{1: Conclusions}

Vegetation cover is an important aspect for maintaining erosion control on construction sites. Vegetation cover is controlled by the application of proper seeding and mulching BMPs. These BMPs are constantly updating as new products are developed in the seeding and mulching industry. Specifications controlled by governing entities should be updated as these new BMPs are introduced to provide for proper vegetation cover on construction sites.

The main BMPs found in this research were topsoil, soil testing and amendments, and mulch. These BMPs all have significant contribution to the establishment and maintenance of vegetation cover. The BMPs were compared with many other state DOT specifications to ensure the proper methods of seeding and mulching were incorporated into the revised WVDOH specifications.

In order to ensure the proper application of these BMPs, a tool was created to calculate the application rates and costs of the new materials in the revised specifications. The tool was developed to take information about a construction site to provide the user with a concise output. The output allowed the user to efficiently compare and contrast the application rates and cost of using the materials from the BMPs on certain construction sites.

The tool was tested with three case studies of sites around the state of West Virginia. The sites were all located along existing highway alignments and thus would fall into the jurisdiction of the WVDOH specifications on seeding and mulching. The sites all contained multiple areas that contained different slopes and types of soils. This allowed for the tool to be tested on processing multiple areas and providing output information to the user in an efficient manner. The user can then use the output information to determine a materials and price estimation for permanent vegetation cover on the site.

\section{2: Recommended Future Research}

The proper test of the revised specifications is to apply the BMPs to a large construction site and monitor the performance. A field test of the specifications would further refine the limitations in the BMPs and allow for a near flawless copy of specifications to be created. Multiple areas across the site could contain different variations of the BMPs within the revised specification. The vegetation cover, variation of species, and biomass data over a long term could determine the recommended BMPs in the revised specifications.

As new BMPs come into the industry, specifications should be updated to contain the most current practices. As such, as the specifications are updated, the tool created with this research should be updated as well. The tool was made to be able to have the addition of new types of seed mixtures, new soil amendments, and new mulching methods. The tool can also be adapted to be used by other entities, such as other state DOTs. As the tool is used, the most effective methods of calculating the cost of BMPs can be implemented. 


\section{Ch. 5 References}

Allen, S. R. (1996). "Evaluation and standardization of rolled erosion control products." Geotextiles and Geomembranes, 14(3-4), 207-221.

Babcock, D., McLaughlin, R. A. (2008). "Mulch Options for Erosion Control on Construction Sites." North Carolina State University, College of Agriculture and Life Sciences Extension. <https://content.ces.ncsu.edu/mulch-options-for-erosion-control-onconstruction-sites> (January 4, 2017).

Babcock, D., McLaughlin, R. A. (2013). "Erosion control effectiveness of straw, hydromulch, and polyacrylamide in a rainfall simulator." Journal of Soil and Water Conservation, 68(3), 221-227.

Benik, S.R., Wilson, B. N., Biesboer, D. D., Hansen, B., Stenlund D. (2003). "Performance of erosion control products on a highway embankment." Transactions of the American Society of Agricultural Engineers, 46(4), 1113-1119.

Booze-Daniels, J. N., Daniels, W. L., Schmidt, R. E., Krouse, J. M., Wright, D. L. (2000). "Establishment of low maintenance vegetation in highway corridors." Reclamation of drastically disturbed lands. Barnhisel et al. Agronomy 41. American Society of Agronomy, Madison, WI.

Brooks, M. A. (1993). "Evaluation of roadside revegetation in central Arizona," dissertation, presented to The University of Arizona at Ann Arbor, MI, in partial fulfillment of the requirements for the degree of Doctor of Philosophy.

Buchholz, D. D. (1983). "Soil Test Interpretations and Recommendations Handbook." <http://aes.missouri.edu/pfcs/soiltest.pdf> (February 27, 2017).

Buchholz, D. D. (1993). "Missouri Limestone Quality: What is ENM?" University of Missouri Extension, Department of Agronomy. <http://extension.missouri.edu/p/G9107> (March 1, 2017).

Buchholz, D. D., Brown, J. R., Crocker, D. K., Garrett, J. D., Hanson, R. G., Lory, J. A., Nathan, M. V., Scharf, P.C., Wheaton, H. N. (2004). "Soil Test Interpretations and Recommendations Handbook." University of Missouri, College of Agriculture, Division of Plant Sciences. <http://aes.missouri.edu/pfcs/soiltest.pdf> (August 23, 2017).

Burroughs, E.R. Jr., King, J. G. (1989). "Reduction of Soil Erosion on Forest Roads." INT-264. USDA Forest Service, Intermountain Research Station: Ogden, UT. <https://www.fs.fed.us/rm/pubs_int/int_gtr264.pdf> (May 22, 2017).

Calvo, P., Nelson, L., Kloepper, J. W. (2014). "Agricultural uses of plant bistimulants." Plant Soil, $383,3-41$.

Commonwealth of Pennsylvania Department of Transportation (PennDOT). (2011). "Specifications." 
<https://www.dot.state.pa.us/public/PubsForms/Publications/Pub_408/408_2011/408_20 11_2/408_2011_2.pdf> (December 6, 2016).

Commonwealth of Pennsylvania Department of Transportation (PennDOT). (2016).

"Specifications."

<https://www.dot.state.pa.us/public/PubsForms/Publications/Pub_408/408_2016/408_20 16_IE/408_2016_IE.pdf> (December 6, 2016).

Davis, J. G., Whiting, D. (2013). "Choosing a Soil Amendment." Colorado State University, Extension. <http://extension.colostate.edu/docs/pubs/garden/07235.pdf> (January 3, 2017).

DeBoyle, N. V., Winokur, R. P. (1985). "Aspen: Ecology and management in the western United States." USDA Forest Service. General Technical Report, RM-119, 1-283.

DeGomez, T., Kolb, P., Kleinman, S. (2015). "Basic Soil Components." Climate, Forests and Woodlands, 54401.

Dong, W., Zhang, X., Wang, H., Dai, X., Sun. X., Qiu, W., Yang, F. (2012). "Effect of Different Fertilizer Application on the Soil Fertility of Paddy Soils in Red Soil Region of Southern China." PLOS ONE, 7(9).

Dudeck, A. E., Swanson, N. P., Mielke, L. N., Dedrick, A. R. (1970). "Mulches for Grass Establishment on Fill Slopes." Agronomy Journal, 60(6), 810-812.

Duiker, S. W. (2004). "Effects of Soil Compaction." PennState College of Agricultural Sciences, Agricultural Research and Cooperative Extension. $<$ http://extension.psu.edu/plants/crops/soil-management/soil-compaction/effects-of-soilcompaction/extension_publication_file> (January 4, 2017).

Duralie Coal Pty Ltd. (2003). "Duralie Coal Mine - Topsoil Stripping Management Plan." <http://www.gloucestercoal.com.au/documents/Enviro_EMP_DCM_Topsoil_March2003. pdf> (February 13, 2017).

Ernst Conservation Seeds, LLC (Ernst Seeds). (2017). "Ernst Seeds Wholesale Price ListSpring 2017." <http://www.ernstseed.com/wp-content/uploads/2017/05/2017-WholesalePricelist.04MAY17.pdf?7a6e54> (August 17, 2017).

Erosion Control Blanket. (2013). "Specification for Hydraulic Growth Mediums (HGMs) \& Organic Soil Amending Materials." <http://www.erosioncontrolblanket.com/wpcontent/uploads/2015/05/DOT_Hydraulic_Growth_Medium_with_revisions_April2013.pdf $>$ (September 20, 2016).

Erosion Control Technology Council (ECTC). (2014). "Standard Specification for Hydraulic Erosion Control Products (HECPs)." <http://www.ectc.org/assets/docs/ectc_apr2014_hecp\%20spec\%20april2014\%20approv ed\%20final.pdf> (October 20, 2016). 
Fenton, M., Albers, C., Ketterings, Q. (2008). "Soil Organic Matter." Agronomy Fact Sheet Series, Fact Sheet 41. Cornell University Cooperative Extension, College of Agriculture and Life Sciences, Department of Crop and Soil Sciences.

<http://franklin.cce.cornell.edu/resources/soil-organic-matter-fact-sheet> (March 1, 2017).

Ferris, F. K. (2006). "Section 4: Topsoil, Subsection C: Topsoil Replacement." Handbook of Western Reclamation Techniques. Vickland, L. E.

<http://www.uwyo.edu/wrrc/_files/docs/handbook_to_western_reclamation_techniques/t opsoil.pdf> (February 13, 2017).

Flynn, R. (2014). "Calculating Fertilizer Costs." New Mexico State, College of Agricultural, Consumer and Environmental Services.

<http://aces.nmsu.edu/pubs/_a/A133/welcome.html> (August 16, 2017).

Fulton, A. (2010). "Primary Plant Nutrients: Nitrogen, Phosphorus, and Potassium." University of California Cooperative Extension, Tehama County. $<$ http://cetehama.ucanr.edu/newsletters/Soil_Testing_Articles-

by_Allan_Fulton39345.pdf> (August 24, 2017).

Funderburg, E. (2001). "What Does Organic Matter Do In Soil?"

<http://www.noble.org/ag/soils/organicmatter/> (October 6, 2016).

GeoTechData. (2013). "Soil friction angle". <http://www.geotechdata.info/parameter/angle-offriction.html> (October 6, 2016).

Halpern, M., Bar-Tal, A., Ofek, M., Minz, D., Muller, T., Yermiyahu, U. (2015). "The use of biostimulants for enhancing nutrient uptake." Advances in Agronomy, 129, 141-174.

Hilvers, G., Hopkinson, L., Davis, E. (2017). "Evaluation of revegetation techniques for roadside construction sites." Journal of Environmental Engineering and Landscape Management, 25(3), 305-315.

Hölzel, N., Otte, A. (2003). "Restoration of a species-rich flood meadow by topsoil removal and diaspore transfer with plant material." Applied Vegetation Science, 6, 131-140.

Hopkinson, L. C., Davis, E., Hilvers, G. (2016). "Vegetation cover at right of way locations." Transportation Research Part D: Transport and Environment, 43, 28-39.

Indiana Department of Transportation (INDOT). (2014). "Standard Specifications." <http://www.in.gov/dot/div/contracts/standards/book/sep13/2014Master.pdf> (December 6, 2016).

Indiana Department of Transportation (INDOT). (2016). "Standard Specifications." <http://www.in.gov/dot/div/contracts/standards/book/sep15/2016Master.pdf> (December 6, 2016). 
Jardin, P. (2012). "The Science of Plant Biostimulants - A bibliographic analsys." <https://link.springer.com/article/10.1007/s11104-014-2131-8> (May 30, 2017).

Jardin, P. (2015). "Plant biostimulants: Definition, concept, main categories and regulation." Scientia Horticulturae, 196, 3-14.

Kauffman, G. L., Kneivel, D. P., Watschke, T. L. (2007). "Effects of a Biostimulant on the Heat Tolerance Associated with Photosynthetic Capacity, Membrane Thermostability, and Polyphenol Production of Perennial Ryegrass." Crop Science, 47, 261-267.

Kay, B. L. (1980). "Mulch choices for erosion control and plant establishment." Weeds, Trees \& Turf, 16-24.

Keller, G., Sherar, J. (2003). "Slope Stabilization and Stability of Cuts and Fills." Low-Volume Roads Engineering Best Management Practices Field Guide. US Agency for International Development (USAID). <https://ntl.bts.gov/lib/24000/24600/24650/Chapters/M_Ch11_Slope_Stabilization.pdf> (August 21, 2017).

Kentucky Transportation Cabinet (KYTC). (2007). "Standard Specifications for Road and Bridge Construction Edition of 2008." <http://transportation.ky.gov/Construction/Standard\%20amd\%20Supplemental\%20Speci fications/Complete\%20KYTC\%20Standard\%20Specifications\%20-\%202008.pdf> (December 6, 2016).

Kentucky Transportation Cabinet (KYTC). (2012). "Standard Specifications for Road and Bridge Construction Edition of 2012."

$<$ http://transportation.ky.gov/Construction/Standard\%20amd\%20Supplemental\%20Speci fications/Complete\%20KYTC\%20Standard\%20Specifications-2012.pdf> (December 6, 2016).

Khan, W., Rayirath, U. P., Subramanian, S., Jithesh, M. N., Rayorath, P., Hodges, D. M., Critchley, A. T., Craigie, J. S., Norrie, J., Prithiviraj, B. (2009). "Seaweed Extracts as Biostimulants of Plant Growth and Development." Journal of Plant Growth Regulation, 28, 386-399.

Koenig, R., Isaman, V. (2010). "Topsoil Quality Guidelines for Landscaping." Utah State University, Cooperative Extension. $<$ https://extension.usu.edu/files/publications/publication/AG-SO-02.pdf > (December 21, 2016).

Kozicki, C. (2014). "Pelletized Lime vs. Ag Lime (and Other Imposters)." $<$ http://feeco.com/pelletized-lime-vs-ag-lime-imposters/> (January 3, 2017). 
Lewandowski, A. (2002). "Organic matter management." University of Minnesota Extension, Department of Agriculture. <http://www.extension.umn.edu/agriculture/soils/soilproperties/soil-management-series/organic-matter-management/> (March 13, 2017).

Maguire, R. O., Heckendorn, S. E. (2017). "Soil Test Recommendations for Virginia." Virginia Tech, Virginia Cooperative Extension.

$<$ http://www.soiltest.vt.edu/content/dam/soiltest_vt_edu/PDF/recommendationguidebook.pdf> (August 23, 2017).

Maryland Department of Transportation State Highway Administration (MDOT). (2008).

"Standard Specifications for Construction and Materials."

<http://www.sha.maryland.gov/ohd/frontpage.pdf> (December 6, 2016).

Masabni, J., Dainello, F., Cotner, S. (2009). "Chapter III: Soils and Fertilizers." Texas Vegetable Growers Handbook. Haby, V.A., Baker, M.L., Feagley, S. Texas A\&M University, College Station, Texas. <http://aggie-horticulture.tamu.edu/vegetable/guides/texasvegetable-growers-handbook/> (October 4, 2017).

McKenzie, R. (1998). "Crop Nutrition and Fertilizer Requirements." Alberta Agriculture and Forestry. <http://www1.agric.gov.ab.ca/\$department/deptdocs.nsf/all/agdex3791> (August 23, 2017).

McLaughlin, R.A., Brown, T. T. (2006). "Evaluation of erosion control products with and without added polyacrylamide." Journal of the American Water Resources Association, 42(3), 675-684.

Michigan Department of Environmental Quality (MDEQ). (2010). "Rolled Erosion Control Products." MDEQ Nonpoint Source Best Management Practices Manual. <https://www.michigan.gov/documents/deq/nps-rolled-erosion-control_332132_7.pdf> (March 13, 2017).

Michigan Department of Transportation (MiDOT). (2003). "2003 Standard Specifications for Construction." <http://mdotcf.state.mi.us/public/specbook/> (December 6, 2016).

Michigan Department of Transportation (MiDOT). (2011). "2012 Standard Specifications for Construction." <http://mdotcf.state.mi.us/public/specbook/2012/> (December 6, 2016).

Minnesota Department of Transportation (MnDOT). (2013). "Standard Specifications for Construction 2014 Edition." <http://www.dot.state.mn.us/pre-letting/spec/2014/2014-StdSpec-for-Construction.pdf> (December 6, 2016).

Minnesota Department of Transportation (MnDOT). (2015). "Standard Specifications for Construction 2016 Edition." <http://www.dot.state.mn.us/preletting/spec/2016/2016specbook.pdf> (December 6, 2016).

Mitchell, C. C., Kessler, J.R. (2006). "Fluid Lime." Agronomy and Soils Series Timely Information, Agriculture \& Natural Resources. Auburn University, Department of 
Agronomy and Soils. <http://www.aces.edu/timelyinfo/Ag\%20Soil/2006/March/s-0106.pdf> (March 1, 2017).

Montoro, J. A., Rogel, J. A, Querejeta, J., Diaz, E., Castillo, V. (2000). "Three hydro-seeding revegetation techniques for soil erosion control on anthropic steep slopes." Land Degradation \& Development, 11, 315-325.

Musick, M., Stenn, H. (2004). "Best Management Practices For Post-Construction Soils." BioCycle, 45 (2), 29.

Natural Resources Conservation Service (NRCS). (2012). "Mulching Principles and Calculations." Agronomy Technical Note No. 8, Pacific Islands Area. <https://www.nrcs.usda.gov/Internet/FSE_DOCUMENTS/nrcs142p2_037081.docx> (March 13, 2017).

New York State Department of Transportation (NYSDOT). (2015). "Standard Specifications Construction and Materials." <https://www.dot.ny.gov/main/businesscenter/engineering/specifications/english-spec-repository/2015_9_Specs_USC_tc.pdf> (December 6, 2016).

New York State Department of Transportation (NYSDOT). (2016). "Standard Specifications Construction and Materials." <https://www.dot.ny.gov/main/businesscenter/engineering/specifications/english-spec-repository/2016_9_Specs_usc_tc.pdf> (December 6, 2016).

North Carolina Department of Transportation (NCDOT). (2006). "Standard Specifications Book." $<$ https://connect.ncdot.gov/resources/Specifications/2006DrawingsEnglishUnits/2006\%2 0Standard\%20Spec\%20Book. pdf> (December 6, 2016).

North Carolina Department of Transportation (NCDOT). (2012). "Standard Specifications for Roads and Structures." $<$ https://connect.ncdot.gov/resources/Specifications/2012StandSpecsMan/PDF/2012\%2 0Standard\%20Specifications\%20Manual\%20with\%20ASTM.pdf> (December 6, 2016).

Olsen, F. J., Jones, J. H. (1988). "Organic amendments compared to topsoil replacement for the reclamation of prime farmland." Transactions of the Illinois Academy of Science, 81(3,4), 215-224).

Paerl, H. W., Gardner, W. S., McCarthy, M. J., Peierls, B. L., Wilhelm, S. W. (2014). "Algal Blooms: Noteworthy nitrogen." Science, 346(6206), 175-176.

Perry, L. (2003). "pH for the Garden." University of Vermont Extension, Department of Plant and Soil Science. <http://pss.uvm.edu/ppp/pubs/oh34.htm> (January 3, 2017).

Profile Products LLC. (2011). "Profile Products Solves Large-Scale South Carolina DOT Project's Extensive Erosion Control Problems." <http://profilelibrary.info/Files/A008019417-1_8-31-2011.pdf> (June 12, 2017). 
Profile Products LLC. (2015). "Hydraulic Mulch: Important differences between cellulose and wood-fiber mulches and their use."

$<$ http://www.profileevs.com/resources/article/hydraulic-mulch-important-differencesbetween-cellulose-and-wood-fiber-mulches-and> (October 20, 2016).

Profile Products LLC. (2017). "Section 3125 14.13 - Hydraulically Applied Erosion Control Engineered Fiber Matrix." < http://profilelibrary.info/Serve.aspx?file=742> (April 10, 2017).

Salon, P. R., Miller, C. F. (2012). "A Guide to Conservation Plantings on Critical Areas for the Northeast." USDA, NRCS.

<https://www.nrcs.usda.gov/Internet/FSE_PLANTMATERIALS/publications/nypmspu114 17.pdf> (March 22, 2017).

Shepperd, W. D., Jones, J. R. (1985). "Nurse Crop." Aspen: Ecology and management in the western United States. DeByle, N. V., Winokur, R. P. Rocky Mountain Forest and Range Experiment Station, Fort Collins, Colorado.

South Carolina Department of Transportation (SCDOT). (2007) "2007 Standard Specifications for Highway Construction." <http://www.scdot.org/doing/doingpdfs/2007_full_specbook.pdf> (December 6, 2016).

South Carolina Department of Transportation (SCDOT). (2011a). "Supplemental Technical Specification for Seeding." <http://www.scdot.org/doing/technicalpdfs/suptechspecs/scm-810-2.pdf> (September 20, 2016).

South Carolina Department of Transportation (SCDOT). (2011b). "Supplemental Technical Specification for Hydraulic Erosion Control Products." <http://www.scdot.org/doing/technicalPDFs/supTechSpecs/SC-M-815-11.pdf> (January 30, 2017).

South Carolina Department of Transportation (SCDOT). (2017). "Tabulation of Bids". < http://info2.scdot.org/bidtabs/BidTabsDocuments/08082017\%20BidTabulation.pdf> (August 16, 2017).

State of Ohio Department of Transportation (ODOT). (2013). "Construction and Material Specifications."

<https://www.dot.state.oh.us/Divisions/ConstructionMgt/OnlineDocs/Specifications/2013 CMS/2013_CMS_11142012_FINAL.PDF> (December 6, 2016).

State of Ohio Department of Transportation (ODOT). (2016). "Construction and Material Specifications." <https://www.dot.state.oh.us/Divisions/ConstructionMgt/OnlineDocs/Specifications/2016 CMS/2016_CMS_11022015_final_to_printer.pdf> (October 13, 2016). 
State of Wisconsin Department of Transportation (WisconsinDOT). (2016). "Standard Specifications for Highway and Structure Construction 2017 Edition." $<$ http://wisconsindot.gov/Pages/doing-bus/eng-consultants/cnsltrsrces/rdwy/stndspec.aspx> (December 6, 2016).

Strohmayer, P. (1999). "Soil Stockpiling for Reclamation and Restorartion activities after Mining and Construction." Restoration and Reclamation Review, Student On-Line Journal, 4(7).

Sultan, S. A. (2016). "Humic Acid's Role in Improving Soil Quality and Plant Growth." $<$ https://www.linkedin.com/pulse/humic-acids-role-improving-soil-quality-plant-growthsyed-arif-sultan> (May 19, 2017).

Sutherland, R. A. (1998). "A critical assessment of the research conducted the hydraulics and erosion control laboratory - a focus on rolled erosion control systems applied to hillslopes." Geotextiles and Geomembranes, 16, 87-118.

UMassAmherst. (2011). "Soil pH and Liming." The Center for Agriculture, Food and the Environment, University of Massachusetts Amherst. <https://ag.umass.edu/turf/factsheets/soil-ph-liming> (May 23, 2017).

Verdyol Biotic Earth. (2015). "Construction Specific for Hydraulic Growth Medium as an alternative for topsoil/compost." <http://www.erosioncontrolblanket.com/wpcontent/uploads/2015/05/CONSTRUCTION-SPECIFICATION-FOR-HYDRAULICGROWTH-MEDIUM.pdf> (May 31, 2017).

Virginia Department of Transportation (VDOT). (2007). "2007 Road and Bridge Specifications." <http://www.virginiadot.org/business/resources/const/2007SpecBook.pdf> (December 6, 2016).

Virginia Department of Transportation (VDOT). (2016). "2016 Road and Bridge Specifications." <http://www.virginiadot.org/business/resources/const/VDOT_2016_RB_Specs.pdf> (December 6, 2016).

West Virginia Department of Environmental Protection (WVDEP). (2006). "Erosion and Sediment Control Best Management Practice Manual." <http://www.dep.wv.gov/WWE/Programs/stormwater/csw/Documents/E\%20and\%20S_B MP_2006.pdf> (October 20, 2016).

West Virginia Division of Highways (WVDOH). (2000). "Standard Specifications Road and Bridges." $<$ http://www.transportation.wv.gov/highways/engineering/Specifications/2003/Y2KSpecB .pdf> (September 25, 2017).

West Virginia Division of Highways (WVDOH). (2010). "Standard Specifications of Roads and Bridges". <http://www.transportation.wv.gov/highways/contractadmin/specifications/Documents/20 
10\%20Standard\%20Specifications\%20Roads\%20and\%20Bridges/Complete\%20Publica tions/2010StandardRoadsnBridges.pdf> (October 18, 2016).

West Virginia Division of Highways (WVDOH). (2016). "2016 Average Unit Bid Prices." <http://www.transportation.wv.gov/highways/contractadmin/Lettings/Documents/2016/20 16_Average_Unit_Bid_Prices\%20-\%20Report.txt> (August 10, 2017).

Wilkins, S., Bennett, K. (2017). "Building Soil Berms." University of Minnesota Extension, SULIS: Sustainable Urban Landscape Information Series." $<$ http://www.extension.umn.edu/garden/landscaping/implement/soil_berms.html> (August 21, 2017).

Zhang, X., Schmidt, R. E. (2000). "Hormone-Containing Products' Impact on Antioxidant Status of Tall Fescue and Creeping Bentgrass Subjected to Drought." Crop Science, 40(5), 1344-1349. 


\section{Appendices \\ Appendix A: Revised WVDOH Section 642 \\ SECTION 642 \\ TEMPORARY POLLUTION CONTROL}

Purpose-The Contractor shall exercise every reasonable precaution throughout the life of the project to control water pollution. Construction of permanent drainage facilities as well as performance of the other contract work which will contribute to the control of siltation shall be accomplished at the earliest practicable time during the life of the Contract. Pollutants such as chemicals, fuels, lubricants, bitumens, raw sewage, and other harmful waste shall not be discharged into or alongside of rivers, streams, impoundments (lakes, reservoirs, etc.) or into natural or manmade or water courses leading thereto. The Contractor shall also comply with the applicable regulations of the Department of Natural Resources and other statues relating to the prevention and abatement of pollution. The purpose of these Specifications is to set forth certain temporary water pollution control measures which shall be required by the Contract in the addition to the above.

\section{1-DESCRIPTION}

This work shall consist of temporary control measures performed during the life of the Contract to control water pollution through the use of berms, ditch checks, check dams, sediment structures (traps, ponds, or dams), mulches, fiber mats, seeding slope drains, and other erosion control devices or construction methods, in accordance with these Specifications and in reasonably close conformity with the lines, grades, thickness and typical cross sections shown on the Plans or established by the Engineer.

The temporary pollution control provisions contained shall be coordinated with the permanent erosion control features specified elsewhere in the Contract to the extent practical to keep total erosion control costs to a minimum. These provisions shall also apply to work conducted outside the project right-of-way, such as operations in a borrow pit or waste site, where such work occurs as a result of the construction of the project.

These temporary water pollution control measures shall be continues until; permanent controls have been established; the need has been eliminated as determined by the Engineer.

\section{2-MATERIALS}

Materials will be considered acceptable when they are capable of accomplishing the intended purpose, do not in themselves contribute to pollution and comply with the following:

i. $\quad$ Mulches may be straw, hydraulic erosion control products conforming to 652.7, matting or other material acceptable to the Engineer. Mulch materials shall be free of noxious weeds. Chemical mulch binders shall conform to the requirements in 715.27.1. 
ii. Slope drains may be constructed of pipe, fiber mats, rubble, Portland cement concrete, bituminous concrete, or other material that will adequately control erosion and is acceptable to the Engineer.

iii. Temporary seed, such as common oats or cereal rye, used in temporary seed mixtures shall be of a commercial grade meeting requirements of the State Seed Law, Temporary seed labeled with the notation "germination below standard" will not be acceptable for use on projects. Temporary seed shall not be used on the project after one year from the date of germination test shown on the label. See 715.28 for minimum germination criterion.

iv. Fertilizer shall be a commercial grade, meeting requirements of the governing state and federal laws.

v. Others as shown on the Plans or specified by the Engineer (i.e. Temporary Pipe, Temporary Structures, etc.).

vi. Ground agricultural limestone shall be of a commercial grade.

vii. Engineering fabric for silt fence shall meet the requirements of 715.11.5 and have a minimum width of 3 feet $(900 \mathrm{~mm})$. Wood, steel, or synthetic support posts having a minimum length of 3 feet $(900 \mathrm{~mm})$ plus the burial depth shall be used. They shall be of sufficient strength to resist damage during installation and to the support applied loads due to material or water build up behind the silt fence.

viii. Dewatering Device shall meet the requirements of 715.11.10.

\section{CONSTRUCTION METHODS}

\section{3-PRECONSTRUCTION CONFERENCE:}

At the pre-construction conference, the Contractor shall submit for approval their schedules and methods for accomplishing the required temporary and permanent pollution control work during the construction stages involving clearing and grubbing; grading and drainage; structures; bases and pavement; and others as applicable. The Contractor shall also submit for approval proposed schedules and methods for pollution control on haul roads, borrow pits, waste sites, and other project related operations, as applicable, conducted outside the right-of-way.

No work shall be started until the above pollution control schedules and methods have been approved by the Engineer.

\section{4-GENERAL REQUIREMENTS}

The Engineer has the authority to limit the surface area of erodible earth material exposed by clearing and grubbing, to limit the surface area of erodible earth material exposed by excavation, borrow and fill operations and to direct the Contractor to provide immediate permanent or temporary pollution control measures as necessary to prevent contamination of adjacent streams or other watercourses, lakes, ponds, or other areas of water impoundment. Such work may involve the construction of temporary berms, ditch checks, check dams, 
sediment structures (traps, ponds or dams), slope drains, and use of temporary mulches, mats, seeding or other control devices or methods as necessary to control erosion.

The Contractor shall incorporate all permanent erosion control features into the project at the earliest practicable time as outlined in their acceptable schedule. Temporary pollution control measures shall be used to correct conditions that develop during construction that were not foreseen during the design stage; that are needed prior to installation of permanent pollution control features, or that are needed temporarily to control erosion that develops during normal construction practices, but are not associated with permanent control features on the project.

Where erosion is likely to be a problem, clearing and grubbing operations shall be so scheduled and performed that grading operations and permanent erosion control features can follow immediately if the project conditions permit; otherwise temporary erosion control measures may be required between successive construction stages.

The Engineer will limit the area of excavation, borrow and embankment operations in progress commensurate with the Contractor's capability and progress in keeping the finish grading, mulching, seeding, and other such permanent pollution control measures current in accordance with the accepted schedule. Should seasonal limitations make such coordination unrealistic, temporary erosion control measures shall be taken immediately to the extent feasible and justified.

Unless otherwise approved in writing by the Engineer, construction operations in rivers, streams, and impoundments shall be restricted to those areas where channel changes are shown on the Plans and to those areas which must be entered for the construction of temporary or permanent structures. Rivers, streams, and impoundments shall be promptly cleared of all falsework, piling, debris or other obstructions placed or caused by the construction operations.

Excavation from any source shall not be deposited in or near rivers, streams, or impoundments or otherwise located in such a manner which might be susceptible to erosion due to high water, flooding, or runoff.

Frequent fording of live streams with construction equipment will not be permitted; therefore, temporary bridges or other structures shall be used wherever an appreciable number of stream crossings are necessary. Unless otherwise approved in writing by the Engineer, mechanized equipment shall not be operated in live streams except as may be required to construct channel changes and temporary or permanent structures.

The location of all local material pits other than commercially operated sources and all waste areas will be subject to the approval of the Engineer, and construction operations shall be conducted and pollution control measures implemented so that, both during and after completion of the work, erosion will not result in water pollution.

The Contractor shall, in accordance with the guidance contained in 642.3, submit schedules and methods in complete consonance with the intent of this Specification to prevent 
water pollution to the maximum extent possible. To provide a positive guide in this area, no more than 750,000 square feet ( 7 hectares) each of erodible soil shall be exposed as a result of (1) clearing and grubbing and (2) excavation, embankment, borrow or waste for a maximum cumulative total of $1,500,000$ square feet (14 hectares) without the approval of the Engineer. Approval to proceed beyond this point will be contingent upon (1) the Engineer's satisfaction, based on performance, as to the Contractor's ability to proceed with their operation and still maintain pollution control at the level contemplated by the Specification, and (2) seeding and mulching of disturbed areas at the Contractor's expense.

It is further understood that regardless of an approval such as the above or compliance with an approved schedule as set forth in 642.3, the Engineer may impose whatever limitations deemed necessary to assure an operation providing for pollution control consistent with the intent of this Specification. Reimbursement for such necessary temporary control measures required to eliminate the need for such limitation will be in accordance with the pertinent sections of this Specification. There will be no additional reimbursement to the Contractor due to losses from delays, production decreases or other causes resulting from the imposition of such a limitation.

In the event of conflict between these requirements and pollution control laws, rules, or regulations of other Federal, State, or local agencies, the more restrictive shall apply.

A Dewatering Device shall be installed on a slight slope so incoming water flows downhill through the Device without creating more erosion. The neck of the Dewatering Device shall be tightly strapped to the discharge hose. The contractor may place the bag on an aggregate or hay bale bed to maximize water flow through the surface area of the bag.

The Dewatering Device is full when it no longer can efficiently filter sediment of pass water at a reasonable rate. Flow rates will vary depending on the size of the Dewatering Device, amount of sediment discharged into the Dewatering Device, the type of ground, rock, or other substance under the bag and the degree of the slope on which the bag lies. The Dewatering Device will normally accommodate flow rates of 1000 gallons per minute (3 785 liters per minute). Use of excessive flow rates or overfilling the Dewatering Device with sediment will cause ruptures of the bag or failure of the hose attachment straps.

The Dewatering Device shall be disposed of as directed by the engineer.

\section{5-SEEDING AND MULCHING}

642.5.1-General: Seeding paid for under this section will include seed mixtures as defined in 642.5.3. The mixtures to be used shall conform to Table 642.5.3.1, according to the season. Seeding and mulching shall be performed on a continual basis starting when earth moving begins in the spring and stopping when the work stops in the winter or weather becomes too cold to operate seeding or mulching equipment. 
Seeding or mulching, or both, shall be performed on all cut and fill slopes, including waste sites and borrow pits, during the construction process. All disturbed areas such as diversion ditches, sediment dams, areas around sediment structures, haul road slopes, cleared and grubbed areas to remain exposed during a period of critical erosion, storage areas, location of batch plants, etc. shall be seeded when and where necessary to eliminate erosion.

Any areas failing to establish a satisfactory stand of grass due to weather conditions, adverse soil conditions, or due to erosion, shall be re-seeded, re-fertilized and re-mulched as directed by the Engineer.

Permanent seeding, or re-application and spot application following the original seeding shall be performed in accordance with 652 .

642.5.2-Schedule of Seeding Operations: Fill slopes, embankments, and waste sites shall be seeded and mulched in 10-ft lifts or 14 days, whichever occurs first.

Cut slopes and borrow pits shall be seeded and mulched each 15-ft depth of excavation or 14 days, whichever occurs first. However, benched areas shall be seeded after completion of each bench, regardless of height.

642.5.3-Seed Mixtures and Planting Seasons: Temporary seed mixtures shall be used on any embankment or area which will be subject to further construction work before the project is completed or outside permanent seeding dates.

When seeding ditches that have or will have flowing water, triple the seeding rate and cover the seed with a rolled erosion control product to prevent ditch erosion.

Table 642.5.3.1-TEMPORARY SEEDING MIXTURES

\begin{tabular}{|l|l|l|}
\hline Variety of Seed & $\begin{array}{l}\text { Spring \& Summer } \\
\text { Mar. 1-Oct. 31 }\end{array}$ & $\begin{array}{l}\text { *Fall \& Winter } \\
\text { Nov. 1-Feb. 28 }\end{array}$ \\
\hline & $\begin{array}{l}\text { Ib per acre } \\
\text { (kg per ha) }\end{array}$ & $\begin{array}{l}\text { Ib per acre } \\
\text { (kg per ha) }\end{array}$ \\
\hline Common Oats & $120(134)$ & \\
\hline Cereal Rye & & $120(134)$ \\
\hline TOTAL & $120(134)$ & $120(134)$ \\
\hline
\end{tabular}

642.5.4-Mulch, Fertilizer and Lime: Mulching, fertilizing, and liming shall be in accordance with 652.7 and the following criteria.

642.5.4.1-Mulch Application: Mulch shall be placed with consideration to the expected life of the temporary seeding. The expected life of the temporary seeding shall be from the time the temporary seed is placed to the time the area is disturbed to continue construction activities. Table 642.5.4.2 shall be used to determine the type of mulch applied for temporary seeding. 
Table 642.5.4.2: MULCH APPLICATION FOR TEMPORARY SEEDING

\begin{tabular}{|l|l|}
\hline $\begin{array}{l}\text { Expected Life of } \\
\text { Temporary Seeding }\end{array}$ & Type of Mulch Application \\
\hline $0-6$ months & Straw Mulch \\
\hline $6-12$ months & $\begin{array}{l}\text { Rolled Erosion Control Products } \\
\text { (RECPs) }\end{array}$ \\
\hline$>12$ months & $\begin{array}{l}\text { Hydraulic Erosion Control Products } \\
\text { (HECPs) }\end{array}$ \\
\hline
\end{tabular}

642.5.4.3-Fertilizer and Lime Application: Fertilizer and lime shall only be used for temporary seeding with an expected life of greater than 6 months.

\section{6- TEMPORARY PIPE, CONTOUR DITCHES, BERMS, SLOPE DRAINS, DITCH CHECKS AND SILT FENCE:}

642.6.1- Temporary Pipe: Temporary pipe and contour ditching shall be provided as necessary to control erosion.

642.6.2- Contour Ditches and Berms: Prior to suspension of construction operations for any appreciable length of time due to seasonal or other conditions, the Contractor shall shape the top of earthwork in such a manner as to permit and facilitate the runoff of rain water and shall construct earth berms along the top edges of embankments to intercept runoff water. The berm construction shall not be permitted to decrease the stability of embankment section. In addition, the Contractor shall construct a berm at the end of each day's operation at the top edges of the embankment:

642.6.3- Slopes Drains: Temporary slope drains shall be provided to accommodate the runoff water intercepted above. The drains shall be located as needed and at nor greater than $500 \mathrm{ft} .(150 \mathrm{~m})$ intervals.

642.6.4- Ditch Checks: Silt fences or bales of straw shall be used to control erosion and trap sediment as required. Ditch check shall be constructed in cut or median ditches by installing silt fence or by using wood, plywood, logs, rocks, steel, or other devices to control velocity and to aid in sediment control.

642.6.5- Silt Fence: The minimum height above ground for the silt fence shall be 2 feet (600 mm). Minimum embedment depth shall be 8 inches $(200 \mathrm{~mm})$. The maximum post spacing shall be based on elongation of the geotextile as measure in accordance with Test Method D 4632. Silt fence geotextile with elongation $50 \%$ shall have a maximum posting space of 4 fee $(1.2 \mathrm{~m})$. Silt fence geotextile with elongation $<50 \%$ shall have a maximum post spacing of 6.5 feet $(2 \mathrm{~m})$. When silt fence is installed in valleys where water can pond behind the fence then the post spacing shall be half of the maximum post space for the geotextile used.

When silt fence is installed by the trenching method the geotextile at the bottom of the fence shall be buried in a " $\mathrm{J}$ " configuration to a minimum depth of 8 inches $(200 \mathrm{~mm})$ in a trench 
so that no flow can pass under the silt fence. Backfill the trench and compact the soil over the geotextile.

When silt fence is installed by the soil slicing method the geotextile shall be installed in a slit in the soil 8 to 12 inches (200 to $300 \mathrm{~mm}$ ) deep so that no flow can pass under the silt fence. Create the slit such that a horizontal chisel point (approx. 3 inches $(75 \mathrm{~mm})$ wide) at the base of a soil slicing blade (approx.. $3 / 4$ inches $(18 \mathrm{~mm}$ ) wide) that slightly disrupts soil upwards as the blade slices through the soil. This upward disruption minimizes horizontal compaction and creates an optimal soil condition for mechanical compaction against the geotextile. Overturning of the soil shall not be permitted. The geotextile shall be mechanically inserted directly behind the soil slicing blade in a simultaneous operation, achieving consistent placement and depth.

The silt fence geotextile shall be spliced together with a sewn seam only at a support post, or two sections of fence may be overlapped.

Silt fence posts shall be drive to a minimum of 20 inches $(500 \mathrm{~mm})$ into the ground. This depth shall be increased to 2 feet $(600 \mathrm{~mm})$ if the fence is placed on a slope of $3: 1(1: 3)$ or greater. Where the minimum depth is impossible to attain, the post shall be adequately secured to prevent overturning of the fence due to loading. The geotextile shall be properly fastened to the upslope side of the fence post.

Silt fences shall be continuous and transverse to the flow. The silt fence shall follow the contours of the site as closely as possible. Place the fence such that the water cannot runoff around the end of the fence.

The silt fence trench shall be compacted on the upstream side first, and then the downstream side. The silt fence trench shall be compacted to a minimum of $90 \%$ of the original ground density and the posts must be installed after compaction of the trench. The trench compaction will be based on visual inspection and the engineer may require compaction testing to verify the visual inspection.

The contractor shall inspect all silt fences immediately after each rainfall and at least daily during prolonged rainfall. The contactor shall immediately correct any deficiencies. The contractor shall also make a daily review of the location of silt fences in areas where construction activities have altered the natural contour and drainage runoff to ensure that the silt fences are properly located for effectiveness. Where deficiencies exist as determined by the engineer, additional silt fence shall be installed as directed by the engineer. When the sediment deposits reaches half the height of the fence the sediment shall be remove or a second silt fence shall be installed as directed by the engineer. The cost of this work shall be paid as "Sediment Removal" or "Silt Fence".

The silt fence shall remain in place until the engineer directs it be removed. Upon removal the contractor shall remove and dispose of any excess sediment accumulations, dress the area to give it a pleasing appearance, and vegetate all bare areas. Removed silt fence may 
be used at other locations provided the geotextile and other material requirements continue to be met to the satisfaction of the engineer.

\section{7- METHOD OF MEASUREMENT:}

The work will be measured for payment at the unit bid prices for the items specified in 642.9.

Berms constructed prior to suspension of construction operations and slope drains will be measured in linear feet (meters); check dams will be measure by the unit; sediment traps, ponds, or dams and sediment removal will be measured by the cubic yard (meter) and included under Item 642008-*; seed will be measured by the pound (kilogram); straw, hay and wood cellulose fiber mulch will be measure by the ton (megagram); wood chips or bark mulch will be measured by the cubic yard (meter); fertilizer and agricultural limestone will be measured by the ton (megagram); matting will be measured by the square yard (meter); contour ditching will be measured by the linear foot (meter). Measurements will be made on the surface of the work done when applicable. Asphalt for anchoring mulch or other chemical binders will be measured separately, but their cost shall be included in the unit price bid for mulch. Cereal rye or cereal wheat added to Type D mixture in fall seeding will not be included for payment but its cost shall be included in the unit prices in 642.9 .

Temporary pipe will be measured by the linear foot (meter) complete and in place. If the Contractor elects to utilize a series of small pipes in lieu of one large pipe, measurement for payment will be made only for a length necessary to extent one conduit under the haul road or sediment dam.

Berms constructed at the end of each day's operation will not be measured for payment but their cost shall be included in the unit bid price for Item 207001-*, " Unclassified Excavation."

Ditch checks will be measured by the unit.

Dewatering Device will be paid per each device used.

Wood chips or bark will be measured by the cubic yard (meter). It is assumed that 17.5 cubic yards (14.75 cubic meters) of chips or bark are equal to one ton (megagram) of straw for seeding. Wood chips or bark mulch will be measured by the truck load or other loose volume measurement, and payment will be made on a one ton (megagram) equivalent of straw for each 17.5 cubic yards ( 14.75 cubic meters) of wood chips or bark mulch.

Quantities re-seeded, re-fertilized, or re-mulched will be measured and included for payment.

The bid price for fertilizer shall be based on 10-20-10 type. When other types of fertilizer are used, pay quantities will be determined using the following tables: 
Table 642.7.1: TYPES OF FERTILIZER

\begin{tabular}{|c|c|c|}
\hline Types of Fertilizer & $\begin{array}{l}\text { Actual Quantity Used } \\
\text { Pounds (kg) }\end{array}$ & Pay Quantity Pounds (kg) \\
\hline $5-10-5$ & 100 & 50 \\
\hline $8-16-8$ & 100 & 80 \\
\hline $10-20-10$ & 100 & 100 \\
\hline $12-24-12$ & 100 & 120 \\
\hline $15-30-15$ & 100 & 150 \\
\hline
\end{tabular}

When fertilizer types other than those shown above are used, the relationship between the pay quantity and the actual quantity used will be established by the Engineer.

Silt fence will be measured by the linear foot (meter) at the bottom of the fence, excluding laps. Decomposed or ineffective fabric in the silt fence which is required to be preplaced after six months form the installation date will be measured and paid for, however, such replacement prior to six months after installation will not be measured for payment.

In the event that temporary erosion and pollution control measures are required due to the Contractor's negligence, carelessness, or failure to install permanent controls as a part of the work as scheduled, or as ordered by the Engineer, such work shall be performed by the Contractor at their own expense. Temporary erosion and pollution control work required, which is not attributed to the Contractor's negligence, careless or failure to install permanent controls, shall be performed as ordered by the Engineer. Where the work to be performed is not attributed to the Contractor's negligence, carelessness or failure to install permanent controls and falls within the Specification for a work item that has a contract price, the units of work will be paid for at the proper contract price. Should the work not be comparable to the project work under the applicable contact items, the Contactor shall perform the work in accordance with 104.3

In case of repeated failure on the part of the Contractor to control erosion, pollution, or siltation, the Engineer reserves the right to employ outside assistance or to use their own forces to provide the necessary corrective measures. Such incurred direct costs plus project engineering costs will be charged to the Contractor and appropriate deductions made from the Contractor's monthly progress estimated.

Temporary pollution control may include construction work outside the right-of-way where such work is necessary as a result of roadway construction such as borrow pit and waste site operation, haul roads and equipment storage sites.

\section{8- BASIS OF PAYMENT:}

The quantities, determined as provided above, will be paid at the contract unit prices bid for the items listed below, which prices and payment shall be full compensation for furnishing all the materials and doing all the work prescribed in a workmanlike and acceptable manner, 
including all labor, tools, equipment, supplies, and incidentals necessary to complete the work, including necessary maintenance, and removal where applicable.

\section{9- PAY ITEMS:}

Table 642.9.1: PAY ITEMS

\begin{tabular}{|c|c|c|}
\hline ITEM & DESCRIPTION & UNIT \\
\hline 642001-* & Temporary Berm & Linear Foot (Meter) \\
\hline $642002-*$ & Slope Drain & Linear Foot (Meter) \\
\hline 642004-* & SEED MIXTURE, "type" & Pound (Kilogram) \\
\hline $642005-*$ & MULCH, "type" & Ton (Megagram) \\
\hline $642006-*$ & Fertilizer & Ton (Megagram) \\
\hline 642007-* & Fiber Matting & Square Yard (Meter) \\
\hline $642008-*$ & Temporary Pipe & Linear Foot (Meter) \\
\hline 642009-* & Contour Ditch & Linear (Meter) \\
\hline 642010-* & Agricultural Limestone & Ton (Megagram) \\
\hline 642011-* & Hay Bale & Each \\
\hline $642012-*$ & Silt Fence & Linear Foot (Meter) \\
\hline 642031 -* $^{-*}$ & Ditch Check & Each \\
\hline $642032-*$ & Check Dam & Each \\
\hline 642033-* & Sediment Trap & Cubic Yard (Meter) \\
\hline 642034-* & Sediment Dam & Cubic Yard (Meter) \\
\hline $642035-*$ & Riser & Each \\
\hline 642036-* & Sediment Removal & Cubic Yard (Meter) \\
\hline $642037-*$ & Sediment Pond & Cubic Yard (Meter) \\
\hline $642037-\star$ & Dewatering Device & Each \\
\hline
\end{tabular}

*Sequence number 


\section{Appendix B: Revised WVDOH Section 651}

\section{SECTION 651}

\section{FURNISHING AND PLACING TOPSOIL}

\section{1-DESCRIPTION:}

This work shall consist of acquiring sites outside the right-of-way from which topsoil can be obtained and the hauling and placing of such material, or hauling and placing of topsoil from stockpiles within the right-of-way, all in accordance with these Specifications and at locations indicated on the Plans or designated by the Engineer.

\section{2-MATERIALS:}

Topsoil shall consist of the uppermost layers of fertile and friable soil that contains humus material. This material varies in thickness in accordance with soil groups and usually possesses a darker color than the subsoil. The texture of the topsoil may vary within the range of natural loam, silty clay loam, and sandy loam. Acceptable topsoil shall contain at least $3 \%$ organic matter.

Topsoil containing less than 3\% organic matter shall be conditioned with biological growth stimulants. The requirements for these amendments shall conform to 715.30 .

\section{CONSTRUCTION METHODS}

\section{3-STRIPPING TOPSOIL:}

Care shall be exercised as to the depth of stripping, and any loads with an excess of subsoil shall be discarded. The Contractor shall remove all heavy grass, weeds, or other vegetation, including root mass, in the areas before stripping.

Topsoil shall be stored on the stripping site out of construction limits, if feasible. Any topsoil that cannot be stored on the construction site must acquire approval by the Engineer to transport any material from the stripping site.

\section{4-TRANSPORTING:}

Topsoil material shall not be placed until the entire roadway (including surface) has been completed, unless otherwise provided for on the Plans or approved in writing. During hauling operations, the surface of the highway shall be kept reasonably clean to avoid creating a traffic hazard.

\section{5-PLACING AND MANIPULATING:}

Areas to be topsoiled shall be brought reasonably close to the lines and grades shown on the Plans or established by the Engineer. Topsoil may not be applied to slopes steeper than $2 \mathrm{H}: 1 \mathrm{~V}$. All slopes less than or equal to $2 \mathrm{H}: 1 \mathrm{~V}$ that do not meet an organic matter of at least $3 \%$ require the application of topsoil. An approved hydraulic growth medium may be used in replace of topsoil if designated by the Engineer and must meet all requirements in 715.31. 
Prior to application, fertilizer lime or sulfur, and other soil amendments shall be added to the topsoil according to the soil analysis, in accordance with section 652.4.1. The Contractor shall then track the surface of the subsoil before the topsoil is placed, unless otherwise permitted, for bonding the topsoil layer with the subsoil.

Topsoil shall be applied at a minimum depth of 6 inches $(152 \mathrm{~mm})$. For Type B and C seed mixtures, the topsoil must be tracked again to compact to a minimum thickness of 4 inches (101 mm). For Type A seeding (lawn type seeding), compact the topsoil and then level. All sites then must be scarified by disking, harrowing, raking, or other approved methods. Depressions and ridges formed by construction equipment, during final grading or scarifying, shall be parallel to the contours.

After spreading the soil, all deleterious materials (large lumps or clods, brush, litter, or other foreign material, and stones exceeding 2 inches (50 $\mathrm{mm}$ ) approximately in any dimension) shall be raked up and removed from the site. For Type A seeding (lawn type seeding), remove all material over 1 inch $(25 \mathrm{~mm})$ in any dimension.

The Contractor shall take all reasonable precautions to avoid injury to existing plant growth, structures, and roadway surface.

\section{6-METHOD OF MEASUREMENT:}

The quantity of work done will be measured in cubic yards (meters) of "Furnishing and Placing Topsoil" or "Placing Stockpiled Topsoil", which shall be the material actually removed from previously selected site or sites outside the right-of-way or from stockpiles within the project limits, and acceptably placed and spread on the areas designated to receive it, as determined from the net total of load tickets of vehicles.

\section{7-BASIS OF PAYMENT:}

The quantities, determined as provided above, will be paid for at the contract unit priced bid for the items listed below, which prices and payments shall be full compensation for furnishing all the materials and doing all the work prescribed in a workmanlike and acceptable manner, including all labor, tools, equipment, supplies, and incidentals necessary to complete the work.

No separate payment will be made for stripping topsoil within the right-of-way limits and transporting or stockpiling of such material.

\section{8-PAY ITEMS:}

Table 651.8.1: PAY ITEMS

\begin{tabular}{|c|c|c|}
\hline ITEM & DESCRIPTION & UNIT \\
\hline $651001-^{*}$ & Furnishing And Placing Topsoil & Cubic Yard (Meter) \\
\hline $65100-^{*}$ & Placing Stockpiled Topsoil & Yard (Meter) \\
\hline
\end{tabular}

*Sequence number 


\section{Appendix C: Revised WVDOH Section 652}

\section{SECTION 652}

\section{SEEDING AND MULCHING}

\section{1-DESCRIPTION:}

This work shall cover all operations incidental to the establishment and maintenance of grass, forb, and leguminous vegetation: including the furnishing and sowing of seed; furnishing and application of fertilizer, limestone, other soil amendments; and mulch material, all in accordance with these Specifications and at locations indicated on the Plans or designated by the Engineer.

\section{2-MATERIALS:}

Materials shall meet the requirements in the following Subsections of Division 700 :

Table 652.2.1: MATERIALS

\begin{tabular}{|l|l|}
\hline \multicolumn{1}{|c|}{ MATERIAL } & \multicolumn{1}{c|}{ SUBSECTION } \\
\hline Matting for Erosion Control & 715.24 \\
\hline $\begin{array}{l}\text { Ground Agricultural } \\
\text { Limestone }\end{array}$ & 715.25 \\
\hline Fertilizers & 715.26 \\
\hline Mulch Materials & 715.27 \\
\hline Seed & 715.28 \\
\hline Inoculating Bacteria & 715.29 \\
\hline Biological Growth Stimulants & 715.30 \\
\hline Hydraulic Growth Mediums & 715.31 \\
\hline Water & $*$ \\
\hline
\end{tabular}

* Water shall be reasonably free from injurious chemicals and other toxic substances harmful to plant life. The source of water used is subject to the approval of the Engineer.

Temporary seed, such as common oats and cereal rye, used in seed mixture B shall be of a commercial grade meeting the requirements of the State Seed Law. Temporary seed labeled with the notation "germinating below standard" shall not be used. Temporary seed shall not be used after one year from date of germination test shown on the label.

Seed other than that specified above shall meet the requirements of 715.28.

Tackifier or chemical mulch binders shall be of commercial grade and conform to the requirements in 715.27.1. 
Topsoil, if called for, shall conform to the requirements in 651. All materials will be subject to approval or rejection, in part or in whole.

\section{CONSTRUCTION METHODS}

\section{3-SEASON OF WORK:}

Permanent seeding or re-application and spot application, following the original seeding, under 652 , shall be performed between the dates of February $15^{\text {th }}$ to June $20^{\text {th }}$ and August $1^{\text {st }}$ to October $31^{\text {st }}$. Specific seeding dates are made for each seed mixture and can be found in 652.5.

Temporary seeding outside the above planting dates shall fall under 642 . Seed shall be applied following construction at any time the weather will allow seeding equipment to operate, under 642, without regard to season.

\section{4-AREA PREPARATION FOR SEEDING AND MULCHING:}

Seeding, fertilizing, liming, applying soil treatments, and mulching shall not be conducted until the specified areas have been brought to lines and grades shown on the Plans. Topsoil or hydraulic growth media shall be spread in accordance to section 651 .

\subsubsection{Soil tests and analysis}

A soil test is required on all areas greater than 1 acre when the area has reached final grade and permanent seeding is the next step. A soil test is optional for areas less than 1 acre and will be determined by the Engineer if required. The area shall be evaluated by the Engineer to determine where the distinguishable representative areas are located. A distinguishable representative area is defined as where visible changes, such as a change in color or texture, in soil occur. All representative areas of the site shall be divided into maximum of 5 acre increments and tested individually.

On each representative soil type, a composite sample is needed. A minimum of ten subsamples of soil from the top 4 to 6 inches will be collected. The subsamples should be taken randomly throughout the area. The subsamples should be thoroughly mixed and the composite sample should be sent to a certified soil testing laboratory for analysis. The laboratory, at a minimum, should report: $\mathrm{pH}$, buffer $\mathrm{pH}$, fertilizer requirements and recommendations, and lime requirements and recommendations.

\subsubsection{Seedbed Preparation}

Areas with 2 Horizontal:1 Vertical $(\mathrm{H}: \mathrm{V})$ slope or flatter, excluding areas involving subsurface drainage from base course material, shall be scarified to produce a seed bed.

For slopes $3 \mathrm{H}: 1 \mathrm{~V}$ and flatter, scarify subsoil to a depth of 2-4 inches (50-100 mm). For slopes $3 \mathrm{H}: 1 \mathrm{~V}$ to $2 \mathrm{H}: 1 \mathrm{~V}$, scarify subsoil to a depth of $0.5-1$ inches $(12-25 \mathrm{~mm})$. Remediation of the $\mathrm{pH}$ should be made to the subsoil at the time of soil scarification, whether lime or sulfur is required based on soil test. See Table 652.4.2 for recommended bulk densities. All large sticks, brush, loose roots, stones exceeding 2 inches $(50 \mathrm{~mm})$ approximately in any dimension, and 
other debris shall be removed prior to seeding operations. Before topsoil application, use a bulldozer to track the soil perpendicular to the slope making track indentations to reduce potential for topsoil slippage. Once check slots are in place, apply and track with a dozer to a minimum thickness of 4 inches $(100 \mathrm{~mm})$. The area shall be free of depressions, ruts, or excessive equipment track marks, other than check slots, on slopes. Seed bed preparation will not be necessary on slopes steeper than $2 \mathrm{H}: 1 \mathrm{~V}$.

Preparation of Lawn Type Areas for Seeding: Lawn type areas will use "Type A" mixture in rest areas, medians, shoulders, and lawns. The seedbed shall be fine graded. The finished grade shall be uniform and free of irregularities or depressions. The finished grade shall be free of weed and plant growth, stones over 1 inch $(25 \mathrm{~mm})$ in diameter, or other debris. The debris will be disposed of as directed by the Engineer. Immediately prior to seeding, all areas shall be cultivated to provide a reasonably firm but friable seedbed. The depth of tillage shall be at least 3 inches $(75 \mathrm{~mm})$ or as directed by the Engineer. Limestone as required and fertilizer as specified shall be worked into the upper 3 inches $(75 \mathrm{~mm})$ of the seedbed before seeding.

Table 652.4.2: RECOMMENDED LIME BULK DENSITIES

\begin{tabular}{|c|c|c|c|c|c|c|}
\hline \multirow[t]{2}{*}{ Soil Texture } & \multicolumn{2}{|c|}{ Ideal Bulk Densities } & \multicolumn{2}{|c|}{$\begin{array}{c}\text { Bulk Densities that } \\
\text { May Affect Root } \\
\text { Growth }\end{array}$} & \multicolumn{2}{|c|}{$\begin{array}{c}\text { Bulk Densities that } \\
\text { Restrict Root } \\
\text { Growth }\end{array}$} \\
\hline & $\mathrm{lb} / \mathrm{ft}^{3}$ & $\left(\mathrm{~g} / \mathrm{cm}^{3}\right)$ & $\mathrm{lb} / \mathrm{ft}^{3}$ & $\left(\mathrm{~g} / \mathrm{cm}^{3}\right)$ & $\mathrm{lb} / \mathrm{ft}^{3}$ & $\left(\mathrm{~g} / \mathrm{cm}^{3}\right)$ \\
\hline $\begin{array}{l}\text { Sands, loamy } \\
\text { sands }\end{array}$ & $<99.9$ & $(<1.60)$ & 105.5 & $(1.69)$ & $>112.4$ & $(>1.80)$ \\
\hline $\begin{array}{l}\text { Sandy loam, } \\
\text { loams }\end{array}$ & $<87.4$ & $(<1.40)$ & 101.8 & $(1.63)$ & $>112.4$ & $(>1.80)$ \\
\hline $\begin{array}{l}\text { Sandy clay } \\
\text { loams, loams, } \\
\text { clay loams }\end{array}$ & $<87.4$ & $(<1.40)$ & 99.9 & $(1.60)$ & $>109.2$ & $(>1.75)$ \\
\hline Silts, silt loams & $<81.2$ & $(<1.30)$ & 99.9 & $(1.60)$ & $>109.2$ & $(>1.75)$ \\
\hline $\begin{array}{l}\text { Silt loams, silty } \\
\text { clay loams }\end{array}$ & $<87.4$ & $(<1.40)$ & 96.8 & $(1.55)$ & $>103.0$ & $(>1.65)$ \\
\hline $\begin{array}{l}\text { Sandy clays, silty } \\
\text { clays, some clay } \\
\text { loams (35-45\% } \\
\text { clay) }\end{array}$ & $<68.7$ & $(<1.10)$ & 93.0 & (1.49) & $>98.6$ & $(>1.58)$ \\
\hline Clays ( $>45 \%$ clay) & $<68.7$ & $(<1.10)$ & 86.8 & $(1.39)$ & $>91.8$ & $(>1.47)$ \\
\hline
\end{tabular}

\subsubsection{Soil Additives and Amendments}

The application rate for limestone, fertilizer, and other soil amendments will be determined by a soil test after cuts and embankments are completed just prior to seeding. The Plans will show the estimated tons (megagrams) of lime, fertilizer, and other soil amendments needed for the job based on general knowledge of the soils in the area. The final application rate will be determined by the Engineer based on the soil test, conducted in accordance with MP 700.04.10. 


\section{5-SOWING SEED:}

Immediately following seedbed preparation, seed shall be sown. Only certified seed shall be used. Certified seed is seed that has been screened to check for satisfactory genetic purity and varietal identity and meets all requirements of State Seed Law. Seed shall not be used after one year from date of germination test shown on the label. Legume seed shall be inoculated with approved cultures, in accordance with the instruction of the manufacturer. Seed may be directly sown with a drill seeder, if site conditions permit. Alternatively, seed may be sown by hydroseeding. When using a hydroseeder, the inoculant shall be increased to five times the normal rate.

If machine breakdown occurs during hydroseeding, the following practices should be used to avoid seed damage:

i. For machine breakdown of 30 minutes to 2 hours, $50 \%$ more seed shall be added to the slurry, based on the proportion of the slurry remaining in the tank.

ii. For machine breakdown of more than 2 hours, a full rate of seed shall be used.

Seed shall be sown by approved methods which provide for uniform distribution of seed. Rates of application and type of seed mixture shall be in accordance with Table 652.6 unless otherwise specified on the Plans.

Specific seeding dates are made for each seed mixture. Type $A$ is to be seeded from February $15^{\text {th }}$ to June $20^{\text {th }}$ and from August $1^{\text {st }}$ to October $31^{\text {st }}$. Type $B$ seed mixture is to be seeded from March $1^{\text {st }}$ to June $20^{\text {th }}$ and October $1^{\text {st }}$ to October $31^{\text {st }}$. Type $C$ mixture is to be seeded from August $1^{\text {st }}$ to October $31^{\text {st }}$. Type $\mathrm{E}$ mixture is to be planted from March $20^{\text {th }}$ to June $30^{\text {th }}$ and October $15^{\text {th }}$ to the first frost.

Reseeding, Refertilizing, and Remulching: Any area failing to establish $70 \%$ of cover by area over $100 \%$ of the site due to any reason shall be reseeded, refertilized, and remulched as directed by 652.8 and by the Engineer. 
Table 652.6: SEED MIXTURES

\begin{tabular}{|c|c|c|c|c|}
\hline Variety of Seed & Type A & Type B & Type C & Type E \\
\hline & $\begin{array}{l}\text { Mowable } \\
\text { Areas }^{\mathrm{b}}\end{array}$ & Cut and Fills & Cool Season & Wet Areas \\
\hline & $\mathrm{lb} / \mathrm{ac}(\mathrm{kg} / \mathrm{ha})$ & $\mathrm{lb} / \mathrm{ac}(\mathrm{kg} / \mathrm{ha})$ & $\mathrm{lb} / \mathrm{ac}(\mathrm{kg} / \mathrm{ha})$ & $\mathrm{lb} / \mathrm{ac}(\mathrm{kg} / \mathrm{ha})$ \\
\hline $\begin{array}{l}\text { Common Oat (Avena sativa) (March 1- } \\
\text { October 31)a }\end{array}$ & & $30 \quad(33.6)$ & & \\
\hline $\begin{array}{l}\text { Cereal Rye (Secale cereal) } \\
\text { (November 1-Feb 28) }^{\mathrm{a}}\end{array}$ & & $\begin{array}{ll}30 & (33.6)\end{array}$ & & \\
\hline Autumn Bentgrass (Agrostis perennans) & $10 \quad(11.2)$ & $(4.1)$ & & \\
\hline $\begin{array}{l}\text { Chewing's Fescue (Festuca rubra ssp. } \\
\text { commutate) }\end{array}$ & $25 \quad(28.0)$ & & & \\
\hline $\begin{array}{l}\text { Hard Fescue 'Chariot' (Festuca } \\
\text { brevipila) }\end{array}$ & $35 \quad(39.2)$ & & $10 \quad(11.2)$ & \\
\hline $\begin{array}{l}\text { Hard Fescue 'Heron' (Festuca ovina } \\
\text { var. duriuscula) }\end{array}$ & $35 \quad(39.2)$ & & $10 \quad(11.2)$ & \\
\hline Creeping Red Fescue (Festuca rubra) & $55 \quad(61.6)$ & & $(17.9)$ & \\
\hline White Clover (Trifolium repens) & $(3.4)$ & & $(7.8)$ & \\
\hline Big Bluestem (Andropogon gerardii) & & $(6.7)$ & & \\
\hline Virginia Wildrye (Elymus virginicus) & & $8.4 \quad(9.4)$ & & $(4.5)$ \\
\hline Switchgrass (Panicum virgatum) & & $6.4 \quad(7.2)$ & & \\
\hline Indiangrass (Sorghastrum nutans) & & $14 \quad(15.7)$ & & \\
\hline $\begin{array}{l}\text { Partridge Pea (Chamaecrista } \\
\text { fasciculate) }\end{array}$ & & $1 \quad(1)$ & & \\
\hline Black-Eyed Susan (Rudbeckia hirta) & & $\begin{array}{ll}0.6 & (0.7)\end{array}$ & & \\
\hline $\begin{array}{l}\text { Narrowleaf Mountainmint } \\
\text { (Pycnanthemum tenuifolium) }\end{array}$ & & $0.1 \quad(0.1)$ & & \\
\hline Wild Bergamot & & $(0.6)$ & & \\
\hline $\begin{array}{l}\text { Panicledleaf Ticktrefoil (Desmodium } \\
\text { paniculatum) }\end{array}$ & & $\begin{array}{ll}0.4 & (0.4)\end{array}$ & & \\
\hline Smooth Oxeye (Heliopsis helianthoides) & & $(0.4)$ & & \\
\hline $\begin{array}{l}\text { Flat-top Goldentop (Euthamia } \\
\text { graminifolia) }\end{array}$ & & $\begin{array}{ll}0.1 & (0.1)\end{array}$ & & \\
\hline Redtop (Agrostis gigantean) & & & $(4.5)$ & \\
\hline Birdsfoot Trefoil (Lotus corniculatus) & & & $(9.0)$ & \\
\hline Fox Sedge (Carex vulpinoidea) & & & & $(4.5)$ \\
\hline Fowl Bluegrass (Poa palustris) & & & & $\begin{array}{ll}3.5 & (3.9)\end{array}$ \\
\hline Redtop Panicgrass (Panicum rigidulum) & & & & $(4.5)$ \\
\hline Common Rush (Juncus effuses) & & & & $(0.6)$ \\
\hline Shallow Sedge (Carex lurida & & & & (3.4) \\
\hline Blue Vervain (Verbena hastate) & & & & $(0.9)$ \\
\hline Wingstem (Verbesina alternifolia) & & & & $(0.2)$ \\
\hline
\end{tabular}

${ }^{a}$ Choose a nurse crop according to season of planting.

b Type A will be utilized for mowable areas. Type A seed mixture shall be used in all urban, suburban, rest areas, WVDOH facilities, and mowable areas along roadways where lawn type turf is desired with mowing maintenance intended. 
652.7-APPLYING MULCH, LIME, FERTILIZER, AND OTHER SOIL AMENDMENTS:

\subsection{1-General}

Whenever permanent or temporary seeding is made on bare soil or newly completed construction work, the following criteria shall be followed in regard to mulching:

i. Hydraulic erosion control products shall be used on all slopes but consult 652.7.2 for further details and specifications.

ii. Rolled erosion control products (RECPS) may be used on slopes less than or equal to $2 \mathrm{H}: 1 \mathrm{~V}$.

iii. Straw mulch (excluding hay) may be used on slopes less than or equal to $4 \mathrm{H}: 1 \mathrm{~V}$.

When using straw mulch, the mulch shall be anchored with a non-toxic tackifier or binder as described in Section 652.7.5. The sequence of application when using straw mulch shall be as follows:

Seed, lime, fertilizer, and other soil amendments shall be sown prior to mulching.

Mulch and non-toxic tackifier or binder shall be placed within 24 hours of sowing seed.

Where the temporary seeding has been destroyed by subsequent construction, the mulch will be the same type and amount as required for bare soil or new construction.

\subsection{2-Hydraulic Erosion Control Products}

Hydraulically applied erosion control products (HECPS) are applied to bare soil by means of a mechanically agitated hydro seeder or by broadcast spreading. Typically, a mixture of cut or shaved wood, straw, bonded fiber matrix, or defibrated organic fiber matrix and a stabilizing emulsion or tackifier constitutes the components of HECP. Paper mulch is not approved for use other than for the use of a mulch binder on straw.

Table 652.7.2.1 lists qualifications for the accepted HECPs in the state of West Virginia. The products are presented in respect to the acceptable slope that the individual HECPs may be applied, as shown in Table 652.7.2.2. 
Table 652.7.2.1: MULCH TYPES

\begin{tabular}{|c|c|c|c|c|c|}
\hline Property & Test Method & Straw & $\begin{array}{l}\text { HECP } \\
\text { Type } 1\end{array}$ & $\begin{array}{l}\text { HECP } \\
\text { Type } 2\end{array}$ & $\begin{array}{l}\text { HECP } \\
\text { Type } 3\end{array}$ \\
\hline \multicolumn{6}{|l|}{ Physical } \\
\hline Color & Observed & Natural & \multicolumn{3}{|c|}{$\begin{array}{l}\text { Colored to contrast application area, shall } \\
\text { not stain concrete or painted surfaces. }\end{array}$} \\
\hline Organic Matter & ASTM D2974 & $100 \%$ & \multicolumn{3}{|c|}{$90 \%$ minimum } \\
\hline $\begin{array}{l}\text { Water Holding } \\
\text { Capacity }\end{array}$ & ASTM D7367 & & $\begin{array}{l}600 \% \\
\text { Minimum }\end{array}$ & $\begin{array}{l}800 \% \\
\text { Minimum }\end{array}$ & $\begin{array}{l}1200 \% \\
\text { Minimum }\end{array}$ \\
\hline Acute Toxicity & $\begin{array}{l}\text { ASTM } 7101 \\
\text { EPA 2021.0-1 }\end{array}$ & \multicolumn{4}{|l|}{ Non Toxic } \\
\hline \multicolumn{6}{|l|}{ Endurance } \\
\hline $\begin{array}{l}\text { Functional } \\
\text { Longevity }\end{array}$ & ASTM D5338 & $\geq 90$ days & $\geq 90$ days & $\geq 180$ days & $\geq 365$ days \\
\hline \multicolumn{6}{|l|}{ Performance } \\
\hline $\begin{array}{l}\text { Maximum Slope } \\
\text { Application }\end{array}$ & Observed & $4.0 \mathrm{H}: 1 \mathrm{~V}$ & 4.0H:1V & $2.0 \mathrm{H}: 1 \mathrm{~V}$ & $0.5 \mathrm{H}: 1 \mathrm{~V}$ \\
\hline Cover Factor & ASTM D6459a & & $C \leq 0.1$ & $C \leq 0.05$ & $C \leq 0.01$ \\
\hline Ground Cover & ASTM D6567 & $>85 \%$ & $>90 \%$ & $>95 \%$ & $>97 \%$ \\
\hline $\begin{array}{l}\text { Vegetation } \\
\text { Establishment }\end{array}$ & ASTM D7322 & & $\begin{array}{l}300 \% \\
\text { Minimum }\end{array}$ & $\begin{array}{l}400 \% \\
\text { Minimum }\end{array}$ & $500 \%$ Minimum \\
\hline
\end{tabular}

${ }^{a}$ ASTM test methods developed for Rolled Erosion Control Products (RECPS) that have been modified to accommodate Hydraulic Erosion Control Products (HECPs).

Table 652.7.2.2: MULCH APPLICATION

\begin{tabular}{|c|c|c|}
\hline Mulch & Applicable Slopes & $\begin{array}{l}\text { Minimum Application Rate } \\
(\mathrm{lb} / \mathrm{acre}-\mathrm{dry})^{\mathrm{a}}(\mathrm{kg} / \mathrm{ha})\end{array}$ \\
\hline HECP Type 1 & $\leq 4 \mathrm{H}: 1 \mathrm{~V}$ & $2,500(2800)$ \\
\hline HECP Type 2 & $4 \mathrm{H}: 1 \mathrm{~V}<\mathrm{S} \leq 2 \mathrm{H}: 1 \mathrm{~V}$ & $3,000(3359)$ \\
\hline HECP Type 3 & $2 \mathrm{H}: 1 \mathrm{~V}<\mathrm{S} \leq 0.5 \mathrm{H}: 1 \mathrm{~V}$ & $4,000^{\mathrm{b}}(4479)$ \\
\hline Straw & $\leq 4 \mathrm{H}: 1 \mathrm{~V}$ & $4,000(4479)$ \\
\hline
\end{tabular}

${ }^{a}$ A higher level of mulch may be applied than that specified on the Plans, Specifications, and other terms of the Contract. In this situation, the higher level mulch is applied at the rate for the actual slope condition of the site in accordance with the mulch tables, and payment is for the actual mulch specified, not the higher level mulch.

${ }^{b} \mathrm{HECP}$ Type 3 may be used for permanent cover applications on slopes $1 \mathrm{H}: 1 \mathrm{~V}$ or greater at a minimum rate of 4,500 pounds per acre $(5039 \mathrm{~kg} / \mathrm{ha})$ as directed by the Engineer only when the proper TRM installation is not practicable due to site constraints.

\subsubsection{3-HECP Type Overview}

Provide a HECP Type 1, 2, or 3 that has no germination or growth inhibiting factors and does not form a water-resistant crust that can inhibit plant growth. Provide a HECP Type 1, 2, or 3 that completely photo-degrades or biodegrades. Add seed, lime, fertilizer, and other soil amendments to the HECP Type 1, 2, or 3 mixture. 
Furnish HECP Type 1, 2, or 3 where all components are pre-packaged by the manufacturer to assure material performance and compliance with the minimum requirements of Table 652.7.2.1. Under no circumstances will field mixing of HECP Type 1, 2, or 3 additives or components be accepted.

HECP Type 1 or 2 shall be applied when the soil is dry and rain is not expected within 24 hours following application. HECP Type 3 shall be applied when the soil is dry and rain is not expected within 8 hours following application. All applications shall have a high degree of certainty that no heavy rain events follow within 48 hours following application.

The HECPs must comply at minimum with Tables 652.7.2.1 and 652.7.2.2.

\subsubsection{4-HECP Type 1}

Provide a HECP Type 1 (stabilized mulch matrix (SMM)) composed of non-toxic fibers consisting of a minimum of $70 \%$ wood fiber or natural fibers that contain non-toxic tackifiers or binders. The HECP Type 1 should be insoluble and non-dispersible after drying to limit raindrop impact.

\subsubsection{5-HECP Type 2}

Provide a HECP Type 2 (bonded fiber matrix (BFM)) consisting of a hydraulically applied matrix composed of a minimum of $70 \%$ of non-toxic defibrated organic fibers with at least one of the following non-toxic:

i. Soil tackifiers,

ii. Soil flocculants,

iii. Soil polymers,

iv. Cross-linked hydro-colloidal polymers, or

v. Cross-linked tackifiers.

The HECP Type 2 should be insoluble and non-dispersible after drying to limit raindrop impact.

Do not use materials composed of paper, cellulose fiber, or any mixture containing paper or cellulose. Do not use materials listed for use as a HECP Type 1. Add seed, legume inoculant, lime, and fertilizer to the HECP Type 2 mixture.

\subsubsection{6-HECP Type 3}

Provide a HECP Type 3 (fiber reinforced matrix (FRM)) consisting of a hydraulically applied matrix composed of a minimum of $70 \%$ of non-toxic defibrated organic fibers and a minimum of $5 \%$ crimped, biodegradable interlocking fibers with least on of the following nontoxic additives:
i. Soil tackifiers,
ii. Soil flocculants,
iii. Soil polymers, 
iv. Cross-linked hydro-colloidal polymers, or

v. Cross-linked tackifiers.

The HECP Type 3 should be insoluble and non-dispersible after drying to limit raindrop impact.

Do not use materials composed of paper, cellulose fiber, or any mixture containing paper or cellulose. Do not use materials listed for use as HECP Type 1 or 2 . Add seed, legume inoculant, lime, and fertilizer to the HECP Type 3 mixture.

\subsection{3-Hydraulic Erosion Control Products Application}

\subsubsection{1-Equipment}

Hydraulic equipment shall be used for the application of a slurry of fertilizer, lime, seed, tackifier, legume inoculant, water, and HECP. The equipment shall have a built-in agitation system with a working capacity sufficient to agitate, suspend, and homogeneously mix a slurry of the specified amount of tackifier, fertilizer, lime, seed, legume inoculant, other soil amendments, water, and HECP. The slurry distribution lines shall be large enough to prevent stoppage. The discharge line shall be equipped with a set of hydraulic spray nozzles which will provide even distribution of the mixture or slurry in the various areas to be seeded. The slurry tank shall be mounted on a traveling unit which may be either self-propelled or drawn, with a separate unit which will place the slurry tank and spray nozzles within sufficient proximity to the areas to be seeded to provide uniform distribution without waste.

\subsubsection{2-Preparation of Slurry and Application of HECPs}

HECPs shall be applied at the specified rate according to the manufacturer, while following the minimum standards specified in Table 652.7.2.2. When seeding into a residue or growth where temporary seeding has previously been performed, the rate will be determined by the Engineer, usually 1,000 lbs. net dry weight per acre $(120 \mathrm{~kg} / \mathrm{ha})$. The HECP, tackifier, seed, legume inoculant, fertilizer, lime, other soil amendments, and water shall all be combined into the slurry tank for distribution of all ingredients in one operation by the hydraulic seeding method. The agitator shall be operating at a rate sufficient to keep all materials in suspension at the time such material is added. The addition of materials into the slurry shall be conducted in the order and time specified by the manufacturer to ensure a homogeneous slurry and survivability of the seed and inoculants. During the spraying operation, a homogenous mixture of suspended solids must be maintained in the tank until the tank is emptied. Upon request of the Engineer, a representative from the HECP manufacturer shall be on site to aid in application and inspection of the mixture application.

\subsection{4-Rolled Erosion Control Products}

Rolled erosion control products (RECPS) shall be composed of natural or polymer fibers bound together to form a matrix to provide erosion control. RECPs shall conform to all requirements within 715.24 . RECPs shall be installed parallel to slope with $100 \%$ surface 
coverage. Single net straw matting shall be installed on slopes less than or equal to $3 \mathrm{H}: 1 \mathrm{~V}$. Double net straw matting shall be installed on slopes less than or equal to $2 \mathrm{H}: 1 \mathrm{~V}$.

RECPs shall be installed as follows for proper long term effectiveness. A 6 inch by 6 inch ( $150 \mathrm{~mm}$ by $150 \mathrm{~mm}$ ) trench shall be dug a minimum of 3 feet (1 meter) above the top of slope. The RECP shall then be laid into the trench with 6 inches $(150 \mathrm{~mm})$ of material extended above the trench to be used for overlap. The RECP laid in the trench shall be anchored with 6 inch $(150 \mathrm{~mm})$ anchors at 1 foot $(300 \mathrm{~mm})$ intervals along the width of the RECP. Backfill soil shall then be added to the trench on top of the anchored RECP and compacted. The 6 inch (150 $\mathrm{mm})$ overlap will then wrap around the backfilled soil and be anchored. The RECP shall then be installed parallel to the slope direction.

Each RECP should overlap another by 6 inches $(150 \mathrm{~mm})$ to provide maximum coverage and stability. Each overlap shall be anchored at 1 foot $(300 \mathrm{~mm})$ intervals along the length of the RECP. RECPs shall be pulled to remove excess slack without breaking contact with the soil surface and anchored to the slope with 6 inch $(150 \mathrm{~mm})$ anchors (stakes or pins). The Engineer may require longer anchors for sandy or loose soils. Refer to table 652.7.4.1 for the minimum anchor frequency requirements.

Table 652.7.4.1: RECP ANCHORING REQUIREMENTS

\begin{tabular}{|l|l|}
\hline Slope Grade & $\begin{array}{l}\text { Anchoring Frequency (anchors/square } \\
\text { yard) (anchors/square meter) }\end{array}$ \\
\hline Up to $3 \mathrm{H}: 1 \mathrm{~V}$ & $1.5(1.25)$ \\
\hline $3 \mathrm{H}: 1 \mathrm{~V}$ to $2 \mathrm{H}: 1 \mathrm{~V}$ & $2.0(1.75)$ \\
\hline
\end{tabular}

\subsection{5-Straw Mulch}

Clean, dry straw mulch may be applied on slopes less than $4 \mathrm{H}: 1 \mathrm{~V}$. Straw mulch may be applied to slopes up to $2 \mathrm{H}: 1 \mathrm{~V}$ if the coverage area is less than 1 acre. Straw mulch shall be applied at a rate of 2 tons per acre (4.5 MG per hectare) with $85 \%$ surface coverage by visual observation. The maximum allowable continuous slope length for straw mulch is 50 feet (15.24 $\mathrm{m})$. Slope interruption devices or rolled erosion control products are required for continuous slope length longer than 50 feet $(15.24 \mathrm{~m})$. Straw mulch must be anchored with a non-toxic tackifier or binder according to the manufacturer specifications. The non-toxic tackifier or binder may be sprayed on the straw as it leaves the blower or it may be applied in a separate operation. The Contractor shall be responsible for any damage to structures from the tackifier or binder.

Straw mulch around buildings, sidewalks, or other structures may be held in place with a form of netting or may be sprayed with a non-toxic tackifier or binder by hand while protecting the structures from over spray.

652.7.6-Limestone 
The kind and rate of application of limestone shall be determined by the soil analysis. Agricultural granular, fast acting lime, or both may be needed depending on the results from the soil analysis. Lime is not required for temporary seeding unless directed by the Engineer.

\subsubsection{1-Agricultural Granular Limestone}

Agricultural granular limestone is used for long term $\mathrm{pH}$ remediation. Agricultural lime shall be uniformly distributed among the area and thoroughly mixed with the soil to a depth of 3 inches $(75 \mathrm{~mm})$. Mixing is not required when spreading lime with hydraulic methods. Agricultural lime shall be spread at the rate recommended by the soil analysis.

\subsubsection{2-Fast Acting Limestone}

Fast acting limestone is used for immediate $\mathrm{pH}$ remediation and should only be used on sites that have time-sensitive guidelines, as directed by the Engineer. Fast acting lime comes in two forms: liquid and dry. The type of fast acting lime shall be determined by the Engineer. Both forms of fast-acting limestone shall be applied at the recommended rate from results of the soil analysis.

\subsection{7-Fertilizer}

The kind and amount of fertilizer per acre (ha) shall be determined by the soil anaylsis. Fertilizer type and quantity will then be prescribed by the Engineer based on a site-by-site analysis. The Engineer may require more than one type and quantity of fertilizer based on the project site characteristics due to varying soil conditions and properties.

Re-application and spot application fertilizer requirements shall be based on soil tests to determine the appropriate type and quantity to mitigate the failed vegetative establishment.

\subsection{8-Biological Growth Stimulants}

Biological growth stimulants shall be applied to all topsoil containing less than $3 \%$ organic matter by weight. The amount and type of stimulant will be determined by the soil analysis. All biological growth stimulants shall conform to 715.30.

\subsection{9-Hydraulic Growth Medium}

Hydraulic growth medium (HGM) shall be used when topsoil cannot be used and the subsoil analyzed for permanent seeding does not contain at least 3\% organic matter by weight. The HGMs shall conform to sections 651 and 715.31.

\subsubsection{0-Wood Chips}

Wood chips, recovered from clearing and grubbing operations, or bark will be acceptable for landscaping at a depth of 2-4 inches (50-100 mm) or used to fill compost socks for erosion control measures instructed by the Engineer.

\section{8-MAINTENANCE OF SEEDED AND MULCHED AREAS:}

\subsection{1-Contractor Maintenance Requirements}


The Contractor shall maintain all seeded areas until final acceptance of the project, minimum of $70 \%$ vegetative cover. All areas shall be protected from equipment and foot traffic and any damaged areas shall be repaired and reseeded. The Engineer will require spot application or re-application, or both, depending upon the completion date and estimated completion time of any remaining items on the project.

\subsection{2-Re-Application}

The re-application of seed, mulch, and fertilizer shall be applied as directed by the Engineer based on the completion date, estimated completion time of any remaining items on the project, and unsatisfactory stand development. The application rates will be based on the stand of vegetation, severity of erosion, and condition or growth of the vegetation as described. Spring seeding shall be re-fertilized and re-seeded as needed in the summer and fall from August $1^{\text {st }}$ to October $31^{\text {st }}$. Summer and fall seeded areas shall be re-seeded and re-fertilized in the following spring from March $1^{\text {st }}$ to June $20^{\text {th }}$.

The following shall be used as a guide for re-application:

i. For areas with less than 50 percent stand or subject to erosion, apply the original specified seed, fertilizer, lime, and mulch rates.

ii. For areas with over 50 percent stand, apply one half the original seed, fertilizer, lime, and mulch rates.

\subsection{3-Spot Application}

Spot application is for areas that have been damaged or not showing a satisfactory stand after the original or re-application, or both for seeding, mulching, liming, and fertilizing of the project site. The quantity of material will be determined by the Engineer based on the size and requirements of the spot applications.

\section{9-METHOD OF MEASUREMENT:}

Ground agricultural limestone, fast-acting limestone, fertilizer, and mulch will be measured by the ton (megagram). Seed will be measured by the pound (kilogram).

Mulch will be measured by the cubic yard (cubic meter). It is assumed that 17.5 cubic yard (14.75 cubic $\mathrm{m}$ ) of mulch is equal to one ton (megagram) of straw. Wood chips or bark mulch will be measured by truck load or other loose volume measurement, and payment will be made on one ton (megagram) equivalent of straw for each 17.5 cubic yard (14.75 cubic m) of mulch.

Re-application and spot application will be measured and included for payment under items in 652.11.

Tackifier or binder for anchoring mulch will not be measured separately, but their cost shall be included in the unit price bid for mulch.

\subsection{0-BASIS OF PAYMENT:}


The quantities determined as provided above, will be paid for at the contract unit prices bid for the items listed below, which prices and payments shall be considered full compensation for furnishing all materials and performing all the work prescribed in a workmanlike and acceptable manner, including all labor, tools, equipment, supplies, and incidentals necessary to complete the work.

Topsoil will be measured and paid for in accordance with the provisions of 651 .

The bid price for fertilizer is based on 10-20-10 type. When other types of fertilizer are determined by the Engineer based on soil tests, pay quantities will be established by the following table.

Table 652.10.1: TYPES OF FERTILIZER

\begin{tabular}{|c|c|c|}
\hline Types of Fertilizer & $\begin{array}{c}\text { Actual Quantity Used } \\
\text { Pounds (kg) }\end{array}$ & Pay Quantity Pounds (kg) \\
\hline $5-10-5$ & 100 & 50 \\
\hline $8-16-8$ & 100 & 80 \\
\hline $10-20-10$ & 100 & 100 \\
\hline $12-24-12$ & 100 & 120 \\
\hline $15-30-15$ & 100 & 150 \\
\hline
\end{tabular}

\subsection{1-PAY ITEMS:}

Table 652.11.1: PAY ITEMS

\begin{tabular}{|c|c|c|}
\hline ITEM & DESCRIPTION & UNIT \\
\hline $65200-^{*}$ & Agricultural Limestone & Ton (Megagram) \\
\hline $65200-^{*}$ & Fast-Acting Limestone, Dry & Pound (Kilogram) \\
\hline $65200-^{*}$ & Fast-Acting Limestone, Liquid & Gallon (Liter) \\
\hline $652004-^{\star}$ & Fertilizer, "type" & Ton (Megagram) \\
\hline $652005-^{*}$ & Seed Mixture, "type" & Pound (Kilogram) \\
\hline $652006-^{*}$ & Mulch, "type" & Ton (Megagram) \\
\hline $652007-^{*}$ & Biological Growth Stimulant, "type" & Pound (Kilogram) \\
\hline $652008-^{*}$ & Hydraulic Growth Medium, "type" & Pound (Kilogram) \\
\hline
\end{tabular}

* Sequence number 


\section{Appendix D: Revised WVDOH Section 715}

\subsection{5-LIMESTONE:}

\subsection{1-Ground Agricultural Limestone:}

Ground agricultural limestone shall consist of high calcitic or dolomitic limestone containing not less than $85 \%$ of total calcium and magnesium carbonates, ground to such fineness and clearly labeled in accordance with the requirements of the West Virginia Department of Agriculture. Ground agricultural limestone shall be furnished and used in accordance with the State Laws. Suppliers must be registered with the West Virginia Department of Agriculture.

\subsection{2-Fast Acting Limestone:}

Fast acting limestone shall meet all requirements of ground agricultural limestone with the West Virginia Department of Agriculture, except percent by weight passing U.S. Standard Sieves.

\subsection{6-FERTILIZERS:}

Commercial fertilizers shall be supplied separately or in mixtures containing the specified percentages of total nitrogen, available phosphoric acid, and water soluble potash. Fertilizer shall be furnished in standard containers with weight, name of plant nutrients and guaranteed percentages, clearly marked, all in accordance with governing State and Federal laws. Brands must be registered with the West Virginia State Department of Agriculture.

\subsection{1-Fertilizer for Seeding:}

Fertilizer for seeding shall consist of any type meeting the minimum specified by the soil analysis. Urea formaldehyde fertilizer shall contain a minimum of 38 percent slowly available nitrogen.

Commercial fertilizer for seeding may be supplied in any of the following forms, subject to the approval of the Engineer.

i. A dry, free flowing fertilizer that may be applied by ordinary agricultural spreaders.

ii. A fertilizer which is water soluble or one which will permit complete suspension of insoluble particles in water, applicable to hydraulic methods of application.

\subsection{2-Fertilizer for Landscape Planting:}

The fertilizer shall be a co-granulated magnesium ammonium phosphate and magnesium potassium phosphate, controlled release, inorganic fertilizer compound (coarse grade). It shall have a guaranteed minimum analysis of: 


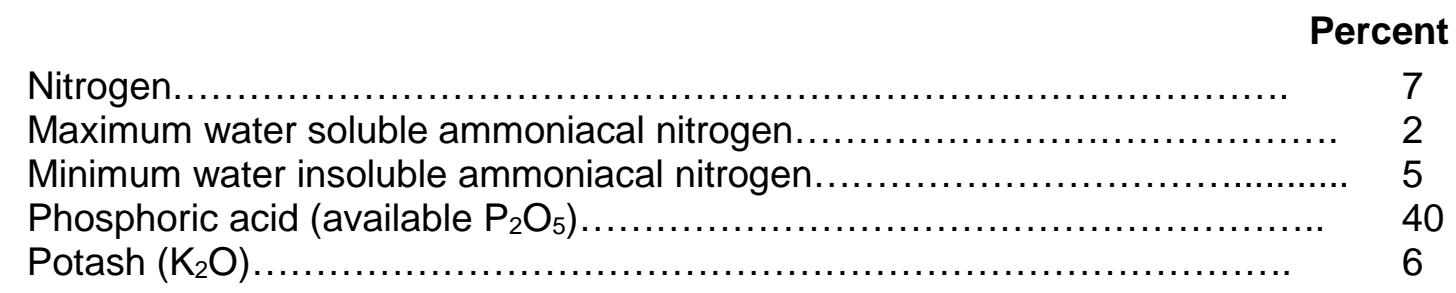

715.27-MULCH MATERIAL:

715.27.1-Mulch Material for Seeding:

\subsubsection{1-Straw Mulch:}

Straw mulch for seeding shall include baled wheat or oats straw, free of seed heads. Hay shall not be used. Straw mulch shall be dry and reasonably free from weeds, sticks, or other foreign material.

Acceptance shall be based on the Division's visual inspection of the material.

\subsubsection{2-Hydraulic Erosion Control Products:}

Mulch for use with the hydraulic application of grass seed shall consist of a minimum of $70 \%$ wood fiber or $70 \%$ of natural fibers with a non-toxic additive(s). It should become insoluble and non-dispersible after drying to limit raindrop impact on soil. Do not use materials composed of paper, cellulose fiber, or any mixture containing paper or cellulose. It shall contain no growth or germination inhibiting factors, shall be dyed green, and shall not form a water-resistant crust.

When the material is agitated in slurry tanks with fertilizers, grass seed, water and other approved additives, the fibers shall become uniformly suspended to form a homogeneous slurry. The hydraulically sprayed slurry shall form a blotter-like ground cover impregnated with grass seed. The ground cover shall permit the absorption of water and allow rainfall or mechanically applied water to percolate to the underlying soil, and it must completely photodegrade or biodegrade.

The hydraulic erosion control product shall conform to the following requirements: 
Table 715.27.1.2: MULCH TYPES

\begin{tabular}{|l|l|l|l|l|}
\hline Property & Test Method & $\begin{array}{l}\text { HECP } \\
\text { Type 1 }\end{array}$ & $\begin{array}{l}\text { HECP } \\
\text { Type 2 }\end{array}$ & $\begin{array}{l}\text { HECP } \\
\text { Type 3 }\end{array}$ \\
\hline Physical & \multicolumn{5}{|l|}{} \\
\hline Color & Observed & $\begin{array}{l}\text { Colored to contrast application area, shall } \\
\text { not stain concrete or painted surfaces. }\end{array}$ \\
\hline Organic Matter & ASTM D2974 & $90 \%$ minimum \\
\hline Water Holding Capacity & ASTM D7367 & $\begin{array}{l}600 \% \\
\text { Minimum }\end{array}$ & $\begin{array}{l}800 \% \\
\text { Minimum }\end{array}$ & $\begin{array}{l}1200 \% \\
\text { Minimum }\end{array}$ \\
\hline Acute Toxicity & $\begin{array}{l}\text { ASTM 7101 } \\
\text { EPA 2021.0-1 }\end{array}$ & Non Toxic \\
\hline Mass per Unit Area $\left(\mathrm{g} / \mathrm{m}^{2}\right)$ & ASTM D6566 & 150 & 250 & 400 \\
\hline Thickness of Fibers $(\mathrm{mm})$ & ASTM D6525 & 2.5 & 3 & 4 \\
\hline Endurance & \multicolumn{5}{|l|}{} \\
\hline Functional Longevity & ASTM D5338 & $\geq 90$ days & $\geq 180$ days & $\geq 365$ days \\
\hline Performance & \multicolumn{5}{|l|}{} \\
\hline $\begin{array}{l}\text { Maximum Slope } \\
\text { Application }\end{array}$ & Observed & $4.0 \mathrm{H}: 1 \mathrm{~V}$ & $2.0 \mathrm{H}: 1 \mathrm{~V}$ & $0.5 \mathrm{H}: 1 \mathrm{~V}$ \\
\hline Cover Factor & ASTM D6459 & $\mathrm{C} \leq 0.1$ & $\mathrm{C} \leq 0.05$ & C $\leq 0.01$ \\
\hline Ground Cover & ASTM D6567 & $>90 \%$ & $>95 \%$ & $>97 \%$ \\
\hline Vegetation Establishment & ASTM D7322 & $\begin{array}{l}300 \% \\
\text { Minimum }\end{array}$ & $\begin{array}{l}400 \% \\
\text { Minimum }\end{array}$ & $500 \%$ Minimum \\
\hline
\end{tabular}

a ASTM test methods developed for Rolled Erosion Control Products (RECPs) that have been modified to accommodate Hydraulic Erosion Control Products (HECPS).

The mulch shall be delivered in packages not to exceed $100 \mathrm{lbs}$. (45 kg). The package shall bear the name of the manufacturer, the net weight and a supplemental statement of the net dry weight.

The material must be approved prior to being used. Acceptance will be based on sampling and testing by the Division for conformance to specifications.

\subsubsection{3-Chemical Mulch Binder:}

A chemical mulch binder shall consist of a polymer synthetic resin, polypectate, or other material which can readily be removed and will give similar adhesive properties as asphalt when sprayed on straw or other fiber mulches.

\subsection{2-Mulch Materials for Landscape Plantings:}

Acceptable materials for mulching shall be shredded bark, buckwheat hulls, wood chips or other organic materials approved by the Engineer.

Certain inorganic materials such as calcined clay, crushed rock or coarse gravel will be acceptable when designated on the Plans. 


\subsection{8-SEED:}

The varieties of grass and legume seeds to be furnished to the project shall bear a tag on each bag of each species showing the lot number, the seedsman's name, the percent of purity, the percent of germination and the weed seed content, in accordance with governing State and Federal laws.

All seeds shall be free from noxious weed seeds as set forth in the West Virginia State seed law and in no event shall the total weed content of any lot of seed or seed mixture exceed one-half percent by weight. The minimum percent purity and germination for the various seeds shall be as shown in Table 715.28. 
Table 715.28: MINIMUM SEED PURITY AND GERMINATION

\begin{tabular}{|c|c|c|}
\hline Variety of Seed & $\begin{array}{l}\text { Minimum Seed } \\
\text { Purity (\%) }\end{array}$ & $\begin{array}{l}\text { Minimum Seed } \\
\text { Germination (\%) }\end{array}$ \\
\hline $\begin{array}{l}\text { Common Oat } \\
\text { (Avena sativa) (March 1-October 31) }\end{array}$ & 98 & 85 \\
\hline $\begin{array}{l}\text { Cereal Rye } \\
\text { (Secale cereal) (November 1-Feburary 28) }\end{array}$ & 98 & 85 \\
\hline Autumn Bentgrass (Agrostis perennans) & 95 & 85 \\
\hline $\begin{array}{l}\text { Chewing's Fescue (Festuca rubra ssp. } \\
\text { commutate) }\end{array}$ & 97 & 85 \\
\hline Hard Fescue 'Chariot' (Festuca brevipila) & 97 & 85 \\
\hline $\begin{array}{l}\text { Hard Fescue 'Heron' (Festuca ovina var. } \\
\text { duriuscula) }\end{array}$ & 97 & 85 \\
\hline Creeping Red Fescue (Festuca rubra) & 97 & 85 \\
\hline $\begin{array}{l}\text { White Clover } \\
\text { (Trifolium repens) }\end{array}$ & 99 & 85 \\
\hline Big Bluestem (Andropogon gerardii) & 85 & 70 \\
\hline Virginia Wildrye (Elymus virginicus) & 85 & 70 \\
\hline Switchgrass (Panicum virgatum) & 95 & 75 \\
\hline Indiangrass (Sorghastrum nutans) & 85 & 70 \\
\hline Partridge Pea (Chamaecrista fasciculate) & 98 & 70 \\
\hline Black-Eyed Susan (Rudbeckia hirta) & 80 & 60 \\
\hline $\begin{array}{l}\text { Narrowleaf Mountainmint (Pycnanthemum } \\
\text { tenuifolium) }\end{array}$ & 80 & 40 \\
\hline $\begin{array}{l}\text { Wild Bergamot } \\
\text { (Monarda fistulosa) }\end{array}$ & 80 & 40 \\
\hline $\begin{array}{l}\text { Panicledleaf Ticktrefoil (Desmodium } \\
\text { paniculatum) }\end{array}$ & 90 & 70 \\
\hline Smooth Oxeye (Heliopsis helianthoides) & 80 & 60 \\
\hline Flat-top Goldentop (Euthamia graminifolia) & 70 & 40 \\
\hline Redtop (Agrostis gigantean) & 92 & 80 \\
\hline Birdsfoot Trefoil (Lotus corniculatus) & 98 & 95 \\
\hline Fox Sedge (Carex vulpinoidea) & 85 & 60 \\
\hline Fowl Bluegrass (Poa palustris) & 90 & 70 \\
\hline Redtop Panicgrass (Panicum rigidulum) & 99 & 70 \\
\hline Common Rush (Juncus effuses) & 85 & 60 \\
\hline Shallow Sedge (Carex Iurida & 85 & 60 \\
\hline Blue Vervain (Verbena hastate) & 80 & 50 \\
\hline Wingstem (Verbesina alternifolia) & 90 & 80 \\
\hline
\end{tabular}

All legumes shall be inoculated according to the supplier's recommendations. However, when seeding with the hydroseeder the inoculant shall be increased to five times the recommended rate.

If test results indicate noncompliance with the above germination or purity requirements, or both, additional seed may be added to give the equivalent germination or purity, or both.

The Division reserves the right to test and reject or approve all seed after delivery on the project. 


\subsection{9-INOCULATING BACTERIA:}

This material shall be used to treat all leguminous seed and shall be a pure culture of nitrogen fixing bacteria selected for maximum vitality an ability to transform nitrogen from the air into soluble nitrates and deposit them in the soil. It shall not be more than one year old.

\subsection{0-BIOLOGICAL GROWTH STIMULANTS:}

Biological growth stimulants (BGSs) shall be applied to topsoil containing less than $3 \%$ organic matter. BGSs shall provide immediate organic matter adjustment to help stimulate seed germination, improve the availability of nutrients to the grass, and generate robust plant growth which is more tolerant of changes in environmental conditions.

Animal by-products, municipal waste products, and liquid fertilizers are not acceptable for use as a BGSs.

BGSs shall not contain germination or growth inhibiting factors or form a water-resistant crust that can inhibit plant growth. BGSs shall come pre-packaged by the manufacturer to assure material performance and compliance with the minimum requirements in Table 715.30.1 No field mixing of components shall occur on site.

Table 715.30.1: MINIMUM BIOLOGICAL GROWTH STIMULANT REQUIREMENTS

\begin{tabular}{|l|c|c|}
\hline BGS Property & Test Method & Required Value \\
\hline Physical & ASTM 7101 & $1 \%$ minimum \\
\hline Humate/Humic Acid & $\begin{array}{c}\text { ASA Toxic } \\
\text { EPA 2021.0-1 }\end{array}$ \\
\hline Pcute Toxicity & ASTM D7322 ${ }^{\mathrm{a}}$ & $200 \%$ minimum \\
\hline Seed Germination & ASTM D7322 & $200 \%$ minimum \\
\hline Plant Height & ASTM D7322 & $110 \%$ minimum \\
\hline Plant Mass &
\end{tabular}

a ASTM test methods developed for Rolled Erosion Control Products (RECPs) that have been modified for comparison to control between 14 and 21 days.

\subsection{1-HYDRAULIC GROWTH MEDIUM:}

Hydraulic growth mediums (HGMs) may be applied on areas to replace topsoil, by instruction of the Engineer, in areas where little to no organic matter is present in the parent subsoil. The HGMs provides a substance on which plants can be grown that requires no curing time, provides exceptional seeding germination and plant establishment, assists in soil building, and provides erosion control. HGMs may be applied to slopes with a steepness factor of $2 \mathrm{H}: 1 \mathrm{~V}$ or less.

The HGMs shall consist of a two part system:

i. Organic Fiber Material: thermally and mechanically processed straw, flexible flax fibers, a minimum of $30 \%$ sphagnum peat moss or compost, and other growth additives. 
ii. Soil Chemistry and Stabilizer Material: soil stabilizer consisting of long-chain and crosslinking molecules in conjunction with a hydrocolloid based bonding agent.

Table 715.31.1: ORGANIC FIBER REQUIREMENTS

\begin{tabular}{|l|c|c|}
\hline Property & Test Method & Value \\
\hline Physical & - & \\
\hline Minimum Peat Moss, Compost Content & - & $30 \%$ \\
\hline $\begin{array}{l}\text { Minimum Thermally and Mechanically Processed } \\
\text { Straw/Flax Fibers }\end{array}$ & & \\
\hline Minimum Total Organic Matter & ASTM D586 & $88 \%$ \\
\hline Maximum Carbon: Nitrogen Ratio & ASTM D1508 & $50: 1$ \\
\hline pH & ASTM D1293 & $5-7$ \\
\hline Performance & & \\
\hline 21 Day Germination & ASTM D7322 & $500 \%$ \\
\hline 60 Day Vegetation Establishment & ASTM D7322 & $500 \%$ \\
\hline Minimum Water Holding Capacity & ASTM D7367 & $900 \%$ \\
\hline
\end{tabular}

The application rates for all components shall be to manufacturer's specifications while following the minimum application rates outlined in Table 715.31.2 and Table 715.31.3.

Table 715.31.2: ORGANIC FIBER MATERIAL MINIMUM RATES

\begin{tabular}{|c|c|}
\hline Property & Minimum Application Rate Ibs/acre (kg/ha) \\
\hline Slope & $3,500(4,000)$ \\
\hline$<4 \mathrm{H}: 1 \mathrm{~V}$ & $4,000(4,500)$ \\
\hline $4 \mathrm{H}: 1 \mathrm{~V}-3 \mathrm{H}: 1 \mathrm{~V}$ & $4,500(5,000)$ \\
\hline $3 \mathrm{H}: 1 \mathrm{~V}-2 \mathrm{H}: 1 \mathrm{~V}$ & $5,000(5,600)$ \\
\hline \% Organic Matter of Subsoil & $4,500(5,000)$ \\
\hline$<0.75$ & $4,000(4,500)$ \\
\hline $0.75-1.5$ & $3,500(4,000)$ \\
\hline $1.5-2.0$ & \\
\hline $2.0-5.0$ & \\
\hline
\end{tabular}

Table 715.31.3: SOIL CHEMISTRY AND STABILIZER MATERIAL MINIMUM RATES

\begin{tabular}{|c|c|c|}
\hline \multirow{2}{*}{ Slope } & Soil Type & $\begin{array}{c}\text { Minimum Application Rate } \\
\text { Ibs/acre (kg/ha) }\end{array}$ \\
\hline \multirow{2}{*}{$<3 \mathrm{H}: 1 \mathrm{~V}$} & Sand & $35(40)$ \\
\cline { 2 - 3 } $3 \mathrm{H}: 1 \mathrm{~V}-2 \mathrm{H}: 1 \mathrm{~V}$ & Clay & $70(80)$ \\
\cline { 2 - 3 } & Sand & $70(80)$ \\
\hline \multirow{2}{*}{2} & Clay & $140(160)$ \\
\hline
\end{tabular}

